Prepared in cooperation with the U.S. Department of Agriculture Natural Resources Conservation Service

\title{
Evaluation of Hydrologic Simulation Models for Fields with Subsurface Drainage to Mitigated Wetlands in Barnes, Dickey, and Sargent Counties, North Dakota
}

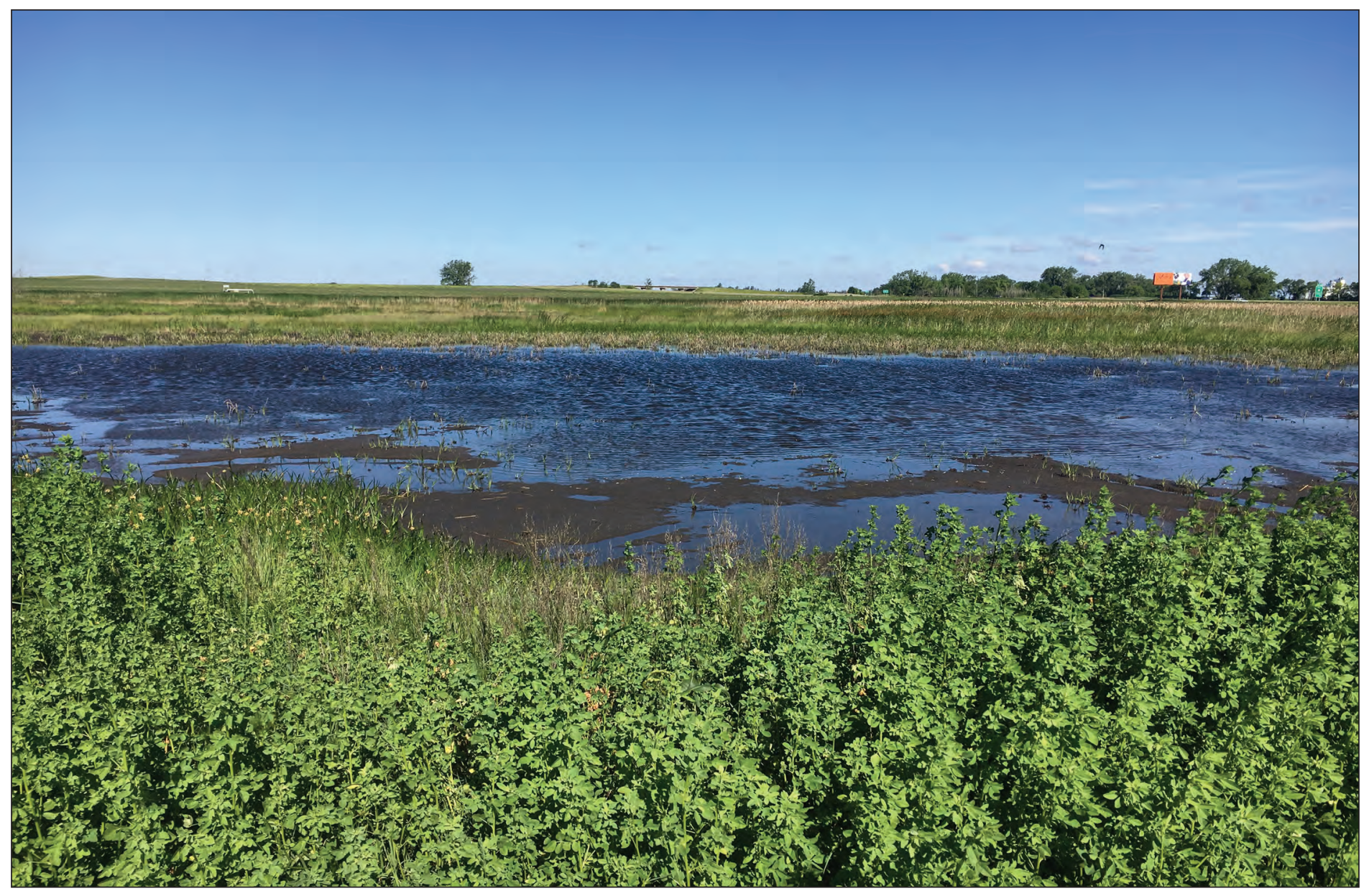

Scientific Investigations Report 2021-5091 
Cover: Photograph of wetland 1 at study area B taken June 15, 2017. Photograph by Kelsey Kolars, U.S. Geological Survey. 


\section{Evaluation of Hydrologic Simulation Models for Fields with Subsurface Drainage to Mitigated Wetlands in Barnes, Dickey, and Sargent Counties, North Dakota}

By Joel M. Galloway, Wyatt S. Tatge, and Spencer L. Wheeling

Prepared in cooperation with the U.S. Department of Agriculture Natural

Resources Conservation Service

Scientific Investigations Report 2021-5091 


\section{U.S. Geological Survey, Reston, Virginia: 2021}

For more information on the USGS - the Federal source for science about the Earth, its natural and living resources, natural hazards, and the environment—visit https://www.usgs.gov or call 1-888-ASK-USGS.

For an overview of USGS information products, including maps, imagery, and publications, visit https://store.usgs.gov/.

Any use of trade, firm, or product names is for descriptive purposes only and does not imply endorsement by the U.S. Government.

Although this information product, for the most part, is in the public domain, it also may contain copyrighted materials as noted in the text. Permission to reproduce copyrighted items must be secured from the copyright owner.

Suggested citation:

Galloway, J.M., Tatge, W.S., and Wheeling, S.L., 2021, Evaluation of hydrologic simulation models for fields with subsurface drainage to mitigated wetlands in Barnes, Dickey, and Sargent Counties, North Dakota: U.S. Geological Survey Scientific Investigations Report 2021-5091, 58 p., https://doi.org/10.3133/sir20215091.

Associated data for this publication:

U.S. Geological Survey, 2020, USGS water data for the Nation: U.S. Geological Survey National Water Information System database, https://doi.org/10.5066/F7P55KJN.

ISSN 2328-0328 (online) 


\section{Contents}

Abstract

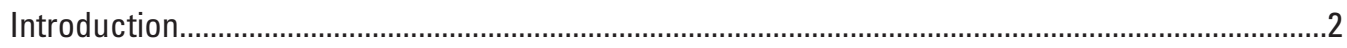

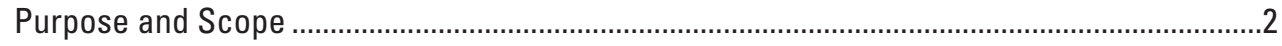

Study Area Descriptions......................................................................................................

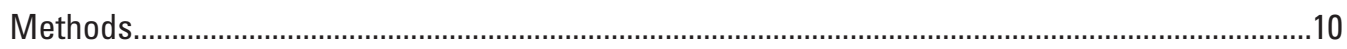

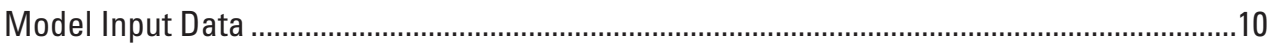

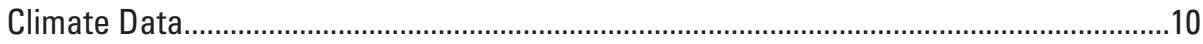

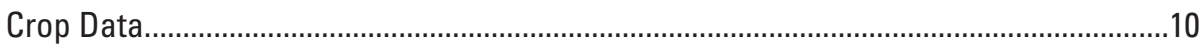

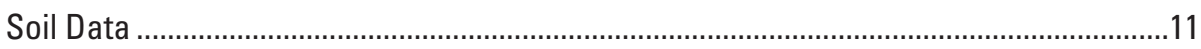

Depth-Capacity Curves and Elevation Data ………………..........................................12

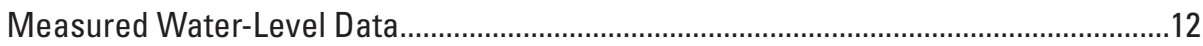

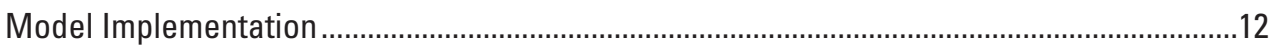

SPAW

Delineation of Modeled Fields .................................................................................

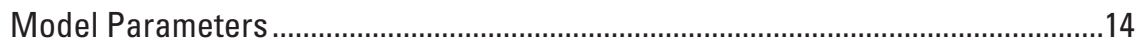

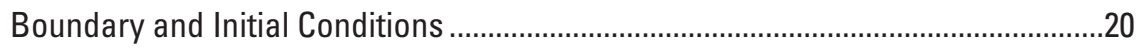

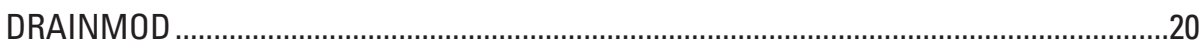

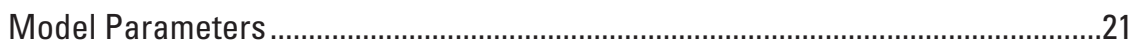

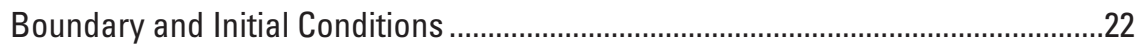

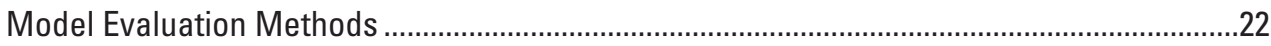

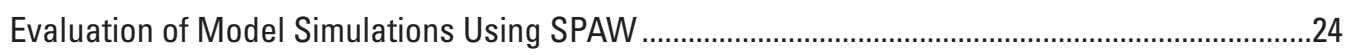

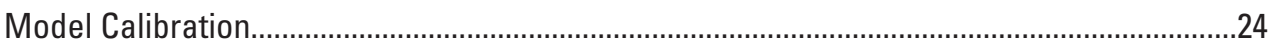

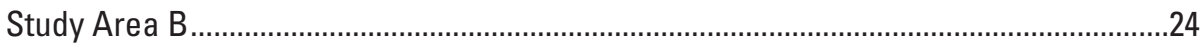

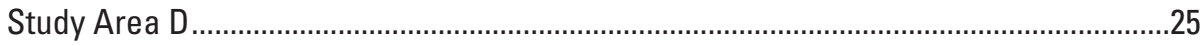

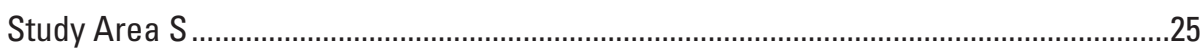

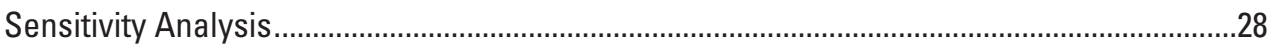

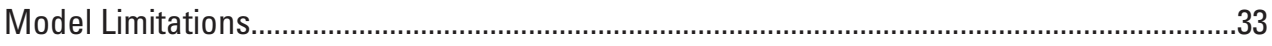

Evaluation of Model Simulations Using DRAINMOD ……...........................................................

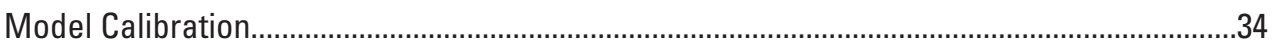

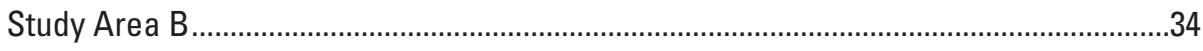

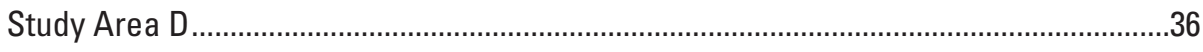

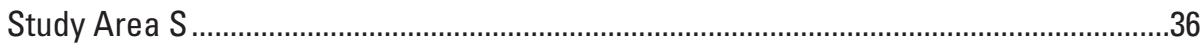

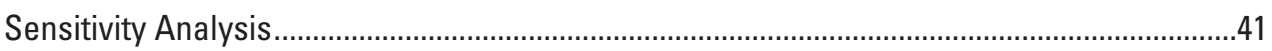

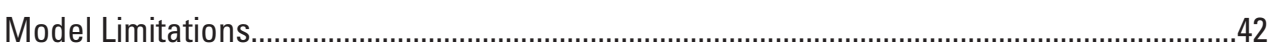

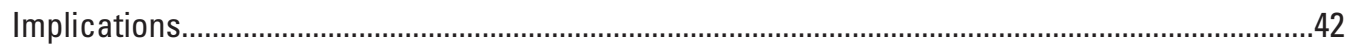

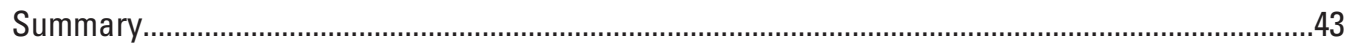

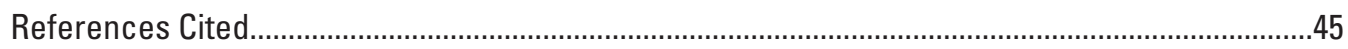

Appendix 1. Additional Model Parameters Used in SPAW Model Applications at Study

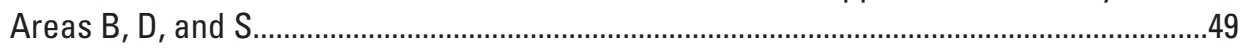

Appendix 2. Additional Model Parameters Used in DRAINMOD Model Applications at

Study Areas B, D, and S ..........................................................................................55 


\section{Figures}

1. Map showing location of study areas in Barnes, Dickey, and Sargent Counties, North Dakota

2. Graphs showing annual precipitation measured from 1970 to 2020 and monthly temperatures measured at climate site precip7 near Litchville, North Dakota....

3. Map showing study area B in Barnes County, North Dakota ............................................5

4. Map showing study area D in Dickey County, North Dakota ............................................

5. Map showing study area $S$ in Sargent County, North Dakota ..........................................

6. Conceptual diagram of processes simulated in the field hydrology model within the SPAW model

7. Conceptual diagram of processes simulated in the pond hydrology model within the SPAW model

8. Maps showing model fields used in SPAW models developed for three study areas ...16

9. Conceptual diagram of processes simulated in the DRAINMOD model.........................21

10. Graphs showing SPAW model results for study area B from January 1, 2003, through December 31, 2018.

11. Graphs showing total annual simulated precipitation, infiltration, and runoff from the SPAW models, 2003 through 2018.

12. Graph showing simulated and measured water depths for wetlands 1 and 2 in study area B, April 2018 through October 2018..

13. Graphs showing SPAW model results for study area D from January 1, 2003, through December 31, 2018.

14. Graphs showing simulated and measured water depths for the wetlands in study area D, April 2018 through October 2018

15. Graphs showing SPAW model results for study area $S$ from January 1, 2003, through December 31, 2018.

16. Graph showing simulated and measured water depths for the wetland in study area S, April 2018 through October 2018

17. Graphs showing DRAINMOD model results for study area B from January 1, 2003, through December 31, 2018.

18. Graphs showing water table depths in study area $\mathrm{B}$...................................................

19. Graphs showing DRAINMOD model results for study area D from January 1, 2003, through December 31, 2018.

20. Graphs showing water table depths in study area $D$

21. DRAINMOD model results for study area $S$ from January 1, 2003, through December 31, 2018.

22. Graphs showing water table depths in study area $\mathrm{S}$

\section{Tables}

1. Subsurface drainage system characteristics for study areas $B, D$, and $S$.

2. Water-level and climate data collection sites used for SPAW and DRAINMOD model development and calibration for study areas B, D, and $S$

3. Climate sites and inverse-distance weights used for estimating climate data for SPAW models at study areas B, D, and S, 2003-18. 
4. Crop data used for fields in SPAW models developed for study areas B, D, and S, 2003-18.

5. Parameters used for crop types in the field hydrology model portion of the SPAW model for study areas B, D, and S, 2003-18...

6. Parameters used for the field hydrology model portion of the SPAW model for study areas B, D, and S, 2003-18

7. Parameters used for the pond model portion of the SPAW models for study areas $B, D$, and $S, 2003-18$

8. Parameters used for DRAINMOD models for study areas B, D, and S, 2003-18 ...........23

9. Results of sensitivity analysis for the SPAW model for study areas B and S, 2003-18.

10. Results of sensitivity analysis for the DRAINMOD model for study area D, 2003-18 .....43

\section{Conversion Factors}

U.S. customary units to International System of Units

\begin{tabular}{|c|c|c|}
\hline Multiply & By & To obtain \\
\hline \multicolumn{3}{|c|}{ Length } \\
\hline inch (in.) & 2.54 & centimeter (cm) \\
\hline inch (in.) & 25.4 & millimeter (mm) \\
\hline foot (ft) & 0.3048 & meter (m) \\
\hline mile (mi) & 1.609 & kilometer (km) \\
\hline \multicolumn{3}{|c|}{ Area } \\
\hline acre & 4,047 & square meter $\left(\mathrm{m}^{2}\right)$ \\
\hline acre & 0.4047 & hectare (ha) \\
\hline acre & 0.004047 & square kilometer $\left(\mathrm{km}^{2}\right)$ \\
\hline \multicolumn{3}{|c|}{ Volume } \\
\hline acre-foot (acre-ft) & 1,233 & cubic meter $\left(\mathrm{m}^{3}\right)$ \\
\hline acre-foot (acre-ft) & 0.001233 & cubic hectometer $\left(\mathrm{hm}^{3}\right)$ \\
\hline \multicolumn{3}{|c|}{ Flow rate } \\
\hline cubic foot per second $\left(\mathrm{ft}^{3} / \mathrm{s}\right)$ & 0.02832 & cubic meter per second $\left(\mathrm{m}^{3} / \mathrm{s}\right)$ \\
\hline gallon per minute (gal/min) & 0.06309 & liter per second (L/s) \\
\hline inch per day (in/d) & 2.54 & centimeters per day (cm/d) \\
\hline inch per hour (in/h) & 2.54 & centimeter per hour (cm/h) \\
\hline \multicolumn{3}{|c|}{ Pressure } \\
\hline pound per square inch $\left(\mathrm{lb} / \mathrm{in}^{2}\right)$ & 6.895 & kilopascal (kPa) \\
\hline \multicolumn{3}{|c|}{ Density } \\
\hline pound per cubic foot (lb/ft³) & 16.02 & kilogram per cubic meter $\left(\mathrm{kg} / \mathrm{m}^{3}\right)$ \\
\hline pound per cubic foot (lb/ft³) & 0.01602 & gram per cubic centimeter $\left(\mathrm{g} / \mathrm{cm}^{3}\right)$ \\
\hline
\end{tabular}

Temperature in degrees Celsius $\left({ }^{\circ} \mathrm{C}\right)$ may be converted to degrees Fahrenheit $\left({ }^{\circ} \mathrm{F}\right)$ as follows: ${ }^{\circ} \mathrm{F}=\left(1.8 \times{ }^{\circ} \mathrm{C}\right)+32$. 


\section{Datum}

Vertical coordinate information is referenced to the North American Vertical Datum of 1988 (NAVD 88).

Horizontal coordinate information is referenced to the North American Datum of 1983 (NAD 83).

\section{Abbreviations}

$\begin{array}{ll}\text { AME } & \text { absolute mean error } \\ \text { ET } & \text { evapotranspiration } \\ \text { GNSS } & \text { Global Navigation Satellite Systems } \\ \text { lidar } & \text { light detection and ranging } \\ \text { NDAWN } & \text { North Dakota Agricultural Weather Network } \\ \text { NRCS } & \text { Natural Resources Conservation Service } \\ \text { NWIS } & \text { National Water Information System } \\ \text { NWS } & \text { National Weather Service } \\ \text { RMSE } & \text { root mean square error } \\ \text { SPAW } & \text { Soil-Plant-Atmosphere-Water } \\ \text { USGS } & \text { U.S. Geological Survey }\end{array}$




\title{
Evaluation of Hydrologic Simulation Models for Fields with Subsurface Drainage to Mitigated Wetlands in Barnes, Dickey, and Sargent Counties, North Dakota
}

\author{
By Joel M. Galloway, Wyatt S. Tatge, and Spencer L. Wheeling
}

\section{Abstract}

Proper identification of wetlands, along with a better understanding of the hydrology of mitigated wetlands, is needed to assist with conservation efforts aimed at maintaining the productivity and ecological function (wetland mitigation) of agricultural lands. The U.S. Geological Survey, in cooperation with the U.S. Department of Agriculture Natural Resources Conservation Service, completed a study to evaluate two models for simulating hydrologic conditions in fields with subsurface drainage to mitigated wetlands at several sites in North Dakota. These two models were evaluated as possible tools for water resource managers to use for designing wetland mitigation projects in the area in the future.

The Soil-Plant-Atmosphere-Water (SPAW) model simulates the daily hydrologic water budgets of agricultural landscapes by two linked routines, one for farm fields (field hydrology) and one for impoundments such as wetlands and ponds (pond model). The DRAINMOD model was used in conjunction with the SPAW model because although the SPAW model can be used to simulate the hydrology of small drainage basins containing wetlands, the SPAW model does not contain routines to simulate drainage, either subsurface drainage or surface (drainage ditches), that can directly affect the wetland hydrology. The wetlands in the study areas in this report are all downstream from and adjacent to drained agricultural fields. SPAW and DRAINMOD models were developed and calibrated at three study areas (study areas B, $\mathrm{D}$, and S) to evaluate how the models simulated field-scale hydrologic characteristics and the water balance in wetlands from January 1, 2003, through December 31, 2018.

The SPAW model developed for study area B included five modeled fields in the field hydrology portion of SPAW that contributed inflow to one wetland simulated in the pond model portion of SPAW. Simulated wetland water depths were most similar to water depths measured at site BWET1, with an absolute mean error of 0.10 foot and a root mean square error of 0.14 foot. Site BWET2 had slightly larger errors, with an absolute mean error of 0.22 foot and a root mean square error of 0.28 foot. Simulated water depths were similar to the pattern of measured water depths at BWET1 and BWET2 from about mid-April 2018 through about mid-September 2018, but overpredicted water depths in the fall from about midSeptember 2018 through about mid-October 2018.

The SPAW model developed for study area D included six modeled fields in the field hydrology portion of SPAW that contributed inflow to five wetlands connected in series in the pond model portion of SPAW. Simulated water depths compared relatively well to water depths in the five wetlands, with the absolute mean error ranging from 0.17 foot (DWET1) to 0.39 foot (DWET2), and the root mean square error ranging from 0.28 foot (DWET1) to 0.56 foot (DWET5).

The SPAW model developed for study area S included one modeled field in the field hydrology portion of SPAW that contributed inflow to one wetland in the pond model portion of SPAW. Among the SPAW models developed for the three study areas, the model for study area S had the best comparison between simulated and measured water depths, with an absolute mean error of 0.06 foot and a root mean square error of 0.10 foot.

DRAINMOD models were developed and calibrated at the three study areas and provided inflow from subsurface drainage discharge to the SPAW models for simulating water levels in wetlands in the study areas. The calibrated DRAINMOD model for study area B showed the variability of hydrologic processes in the modeled field throughout the wide range of hydrologic conditions from January 1, 2003, through December 31, 2018. In general, the discharge through the modeled subsurface drainage system was in the spring and early summer (April through June) most years, with little to no discharge later in the year. Although the subsurface drainage system in study area D was the most complex among the three study areas and was simplified into a uniform system within DRAINMOD, simulated water table depths at study area D correlated better to measured water table depths compared to results from the model applications at the other two study areas. Simulated water table depths had an absolute mean error of 0.30 foot and root mean square error of 0.37 foot at site DGW1 and an absolute mean error of 0.29 foot and a root mean square error of 0.34 foot at site DGW2. Although the subsurface drainage system in study area $\mathrm{S}$ was the simplest and the modeled field was the smallest among the three study areas, simulated water table depths at study area S did 
not correlate as well to measured water table depths compared to results from the model applications at the other two study areas.

The SPAW and DRAINMOD model applications at the three study areas in southeast North Dakota adequately simulated the hydrologic processes for fields with subsurface drainage that are connected to adjacent wetlands. However, more measured data would be needed to fully evaluate the models throughout the range of possible climatic conditions.

\section{Introduction}

North Dakota (fig. 1) has had long and short wet weather cycles that have altered the hydrology of many agricultural drainage basins (van der Valk, 2005). The result of such wet conditions has increased the extent and frequency of waterlogged soils and has established new wetland habitats where they may not have existed previously. Proper identification of wetlands, along with a better understanding of the hydrology of mitigated wetlands, are needed to assist with conservation efforts aimed at maintaining the productivity as well as ecological function (wetland mitigation) of agricultural lands. Mitigated wetlands generally refers to wetlands that have been created, restored, or enhanced to mitigate previous wetland losses. A variety of programs have been established to address mitigated wetland efforts, such as wetland conservation provisions of the National Food Security Act of 1985 (U.S. Department of Agriculture, 1986); Wetland Protection Policy under Executive Order 11990 (National Archives, 2016); and wetland determinations in accordance with the U.S. Army Corps of Engineers Wetlands Delineation Manual, Wetland Reserve Program (U.S. Army Corps of Engineers, 1987). A variety of tools are needed to assist managers with implementing these programs.

The U.S. Geological Survey (USGS), in cooperation with the U.S. Department of Agriculture Natural Resources Conservation Service (NRCS), completed a study to evaluate two models for simulating hydrologic conditions in fields with subsurface drainage to mitigated wetlands at several sites in North Dakota. Two models that have been used in other applications were selected for evaluation at sites in Barnes, Dickey, and Sargent Counties in North Dakota (fig. 1) - the SoilPlant-Atmosphere-Water (SPAW) model (Saxton and Willey, 2004) and the DRAINMOD model (Skaggs, 1978, 1980). The SPAW model can be used for investigating the hydrology of small drainage basins containing wetlands, but does not work well when drainage, either subsurface or surface (for example, drainage ditches), directly affects the wetland hydrology. For this reason, the DRAINMOD model was used in conjunction with the SPAW model because the wetlands of interest were downstream from and adjacent to subsurface drained agricultural fields. DRAINMOD was developed at North Carolina State University in the mid-1970s (Skaggs, 1978, 1980) and is based on a water balance in the soil profile that uses climatological records to simulate the performance of drainage and water table control systems. Many of the applications for these models were done in the southern United States, and few applications have been documented in the colder climate Prairie Pothole Region (fig. 1) across the north-central United States, including North Dakota. These two models were evaluated as possible tools that water resource managers could use for designing wetland mitigation projects in the area in the future.

\section{Purpose and Scope}

The purpose of this report is to describe the development and evaluation of the applicability of the SPAW and DRAINMOD models and their overall ability to simulate field and wetland hydrology from fields with subsurface drainage. Evaluation of the models included parameter development for the SPAW and DRAINMOD models in three study areas with varied site characteristics, model calibration by comparison to measured data, and assessment of the sensitivity and limitations of each model. Models were developed for simulating the hydrology of fields with subsurface drainage and wetland combinations at study areas in Barnes, Dickey, and Sargent Counties in North Dakota (study areas B, D, and S, respectively, fig. 1) from January 1, 2003 through December 31, 2018. Wetland water-level data and shallow groundwater-level data were collected from April 2018 through October 2018 to evaluate the performance of the models in simulating the hydrology in each study area.

\section{Study Area Descriptions}

Three study areas were selected for analysis that had fields with a wetland or several wetlands adjacent to a field with subsurface drainage in Barnes, Dickey, and Sargent Counties (study areas B, D, and S, respectively). The areas are in the Northern Glaciated Plains of the Prairie Pothole Region in central to southeast North Dakota (Omernik and Griffith, 2014; Tangen and Finocchiaro, 2017). The Prairie Pothole Region is characterized by millions of isolated wetlands interspersed among a landscape mosaic of agricultural fields and grasslands (Dahl, 2014). Increased crop demands in the last 15 years have led to a rapid expansion of land-use conversion from grassland to cropland and the expansion in use of subsurface drainage in the eastern portions of North and South Dakota (Tangen and Finocchiaro, 2017). This expansion has been associated with changes in cropping practices and greater use of wetland catchments and other low-production agricultural areas. On average (1952-2020), precipitation near the three study areas is about 21 inches per year (measured at climate site precip7, fig. 1). During the model period (2003-18), annual precipitation ranged from 15 inches in 2006 to 28 inches in 2010 (fig. 2). Generally, more precipitation falls in May, June, and July, and less precipitation falls in January and February (High Plains Regional Climate Center, 2020). 


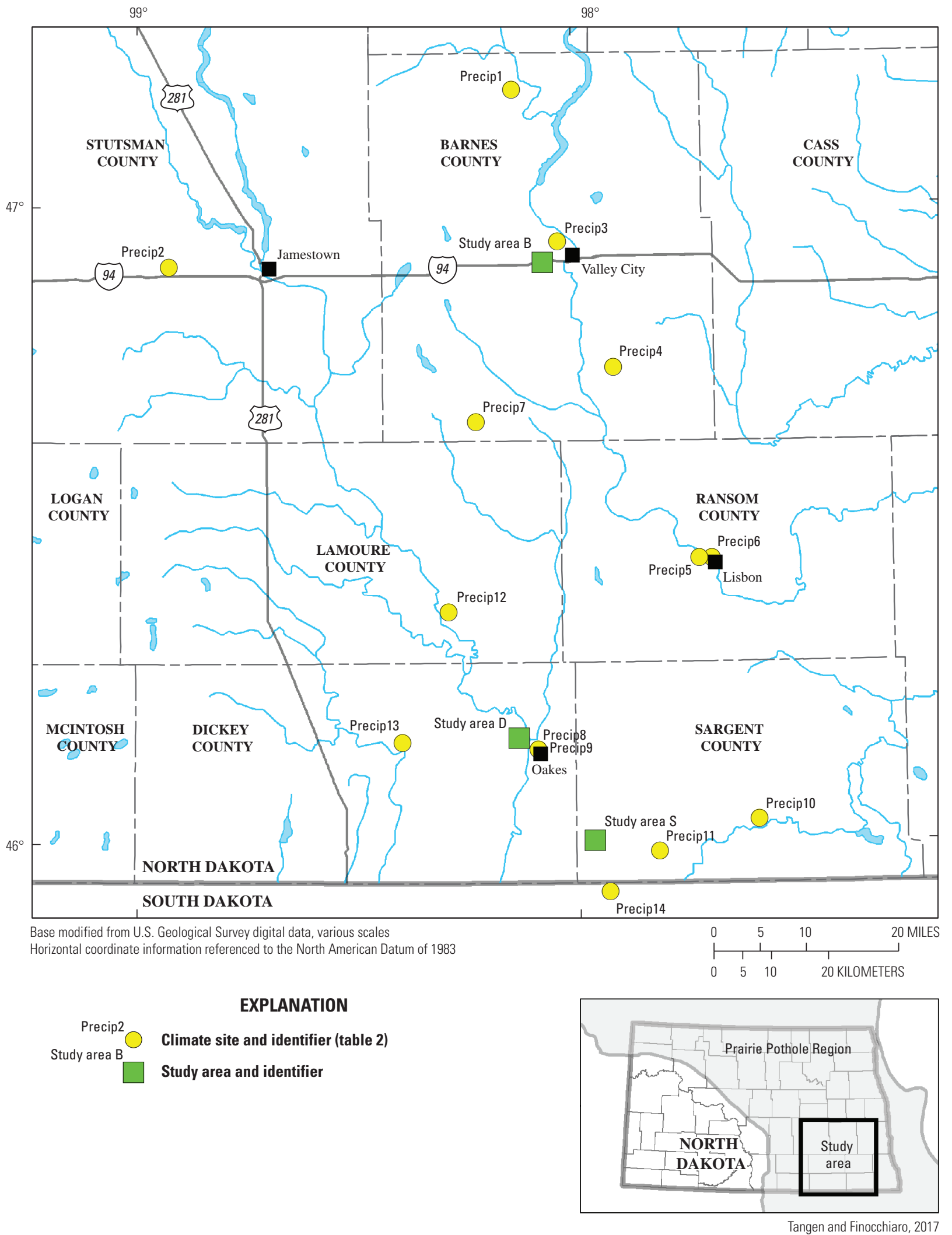

Figure 1. Location of study areas in Barnes, Dickey, and Sargent Counties, North Dakota. 

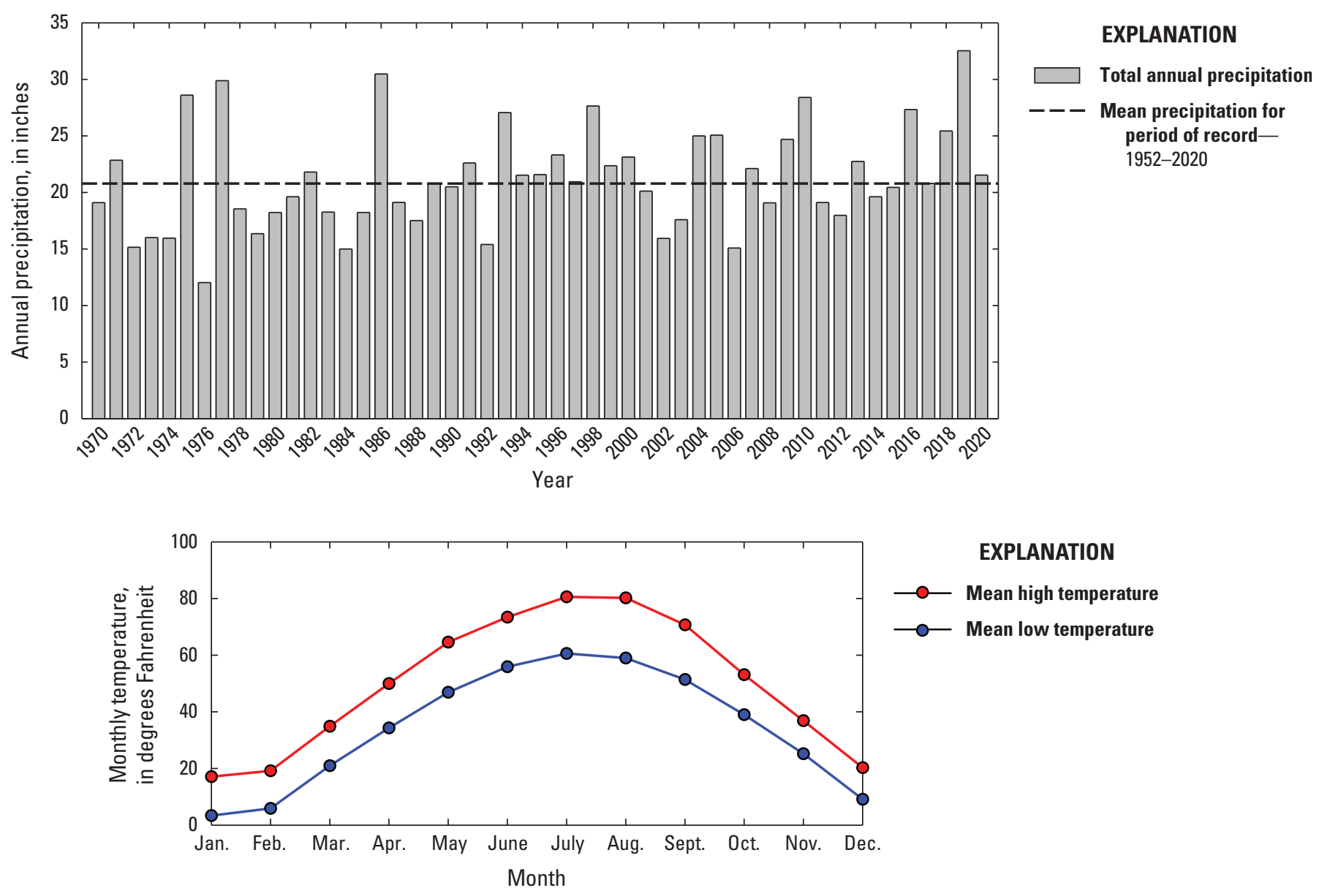

Figure 2. Annual precipitation measured from 1970 to 2020 and monthly temperatures measured at climate site precip7 (site number USC00325230, National Weather Service, 2021) near Litchville, North Dakota.

Study area B in Barnes County is just south of Interstate 94 about 4 miles west of Valley City, N. Dak. (figs. 1 and 3). The study area has mixture of natural and mitigated wetlands on the north side of the study area, with a large natural wetland area (wetland 4) surrounded by one mitigated wetland area on the northwest side of wetland 4 (wetland 1) and two on the southwest side of wetland 4 (wetlands 2 and 3) (fig. 3). The contributing surface drainage area determined using the USGS program StreamStats (U.S. Geological Survey, 2020b) extends beyond the study area to the west and southwest and is about 850 acres in size. The study area has about 100 acres of subsurface-drained fields (Jonathan Petersen, Natural Resources Conservation Services, written commun., 2019; fig. 3). The drainage system discharges into wetland 4 through an outlet that includes a sump and pump system (fig. 3). The drainage system includes an array of 4-inch pipe about 3 feet (ft) deep in the soil zone, and the array of pipe is connected to a series of 5- to 12-inch collector pipes that lead to the subsurface drainage system outlet (table 1). Crops planted in the area drained by the drainage system were rotated mostly between corn and soybeans, with some portions periodically planted with spring wheat from 2003 through 2018 (U.S. Department of Agriculture, 2020a). One portion of the study area without subsurface drainage had pasture with warm-season grasses during the modeling period. Soils in the area were mostly loams including Hamerly-Tonka complex, Barnes-Buse loam, and Vallers loam soils (U.S. Department of Agriculture, 2020b).

Study area D in Dickey County is about 2 miles northwest of Oakes, N. Dak. (figs. 1 and 4). The study area includes a series of five wetlands connected by culverts on the east edge of the study area (fig. 4). The contributing surface drainage area determined using the USGS program StreamStats (U.S. Geological Survey, 2020b) extends beyond the study area to the west and south and is about 1,070 acres in size. The study area has about 665 acres of fields with a subsurface drainage system (Jonathan Petersen, Natural Resources Conservation Services, written commun., 2019; fig. 4). The system was placed in 2011 and 2014 and includes separate arrays of 4-, 8- and 10-inch pipe about 2 to $3 \mathrm{ft}$ deep in the soil zone. The arrays of pipe are connected to three outlets that drain to the adjacent wetlands (table 1; fig. 4). Crops planted in the fields with subsurface drainage were rotated mostly between corn and soybeans during the modeling period (2003-18; U.S. Department of Agriculture, 2020a). Part of the study area had bare soil during 2004-06 and pasture during 


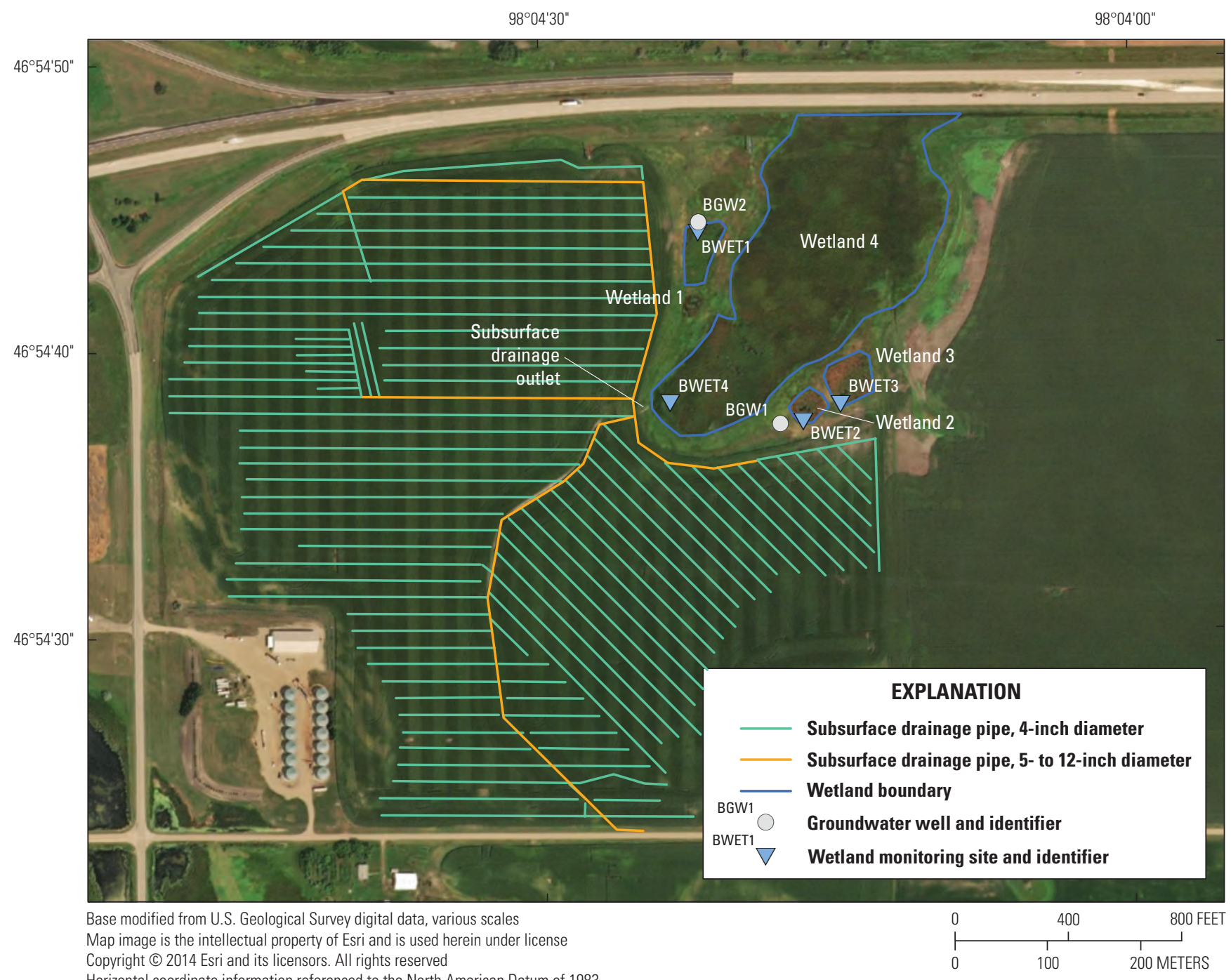

Figure 3. Study area B in Barnes County, North Dakota.

Table 1. Subsurface drainage system characteristics for study areas B, D, and S.

\begin{tabular}{lccc}
\hline \multicolumn{1}{c}{ Characteristic } & \multicolumn{3}{c}{ Study area } \\
\cline { 2 - 4 } & B & D & S \\
\hline Drainpipe depth, in feet & 3 & 2 to 3 & 2 to 3 \\
Drainpipe spacing, in feet & 60 & 65 to 65 & 65 to 70 \\
Diameter of drainpipes, in inches & 4 & 4 & 6 \\
Diameter of main collector pipes, in inches & $5,6,8,10,12$ & 8,10 & 6.6 \\
Slope of drainpipes, in percent & 0.01 & 0.3 & 54.4 \\
Drained field area, in acres & 101.3 & 664.7 & \\
\hline
\end{tabular}




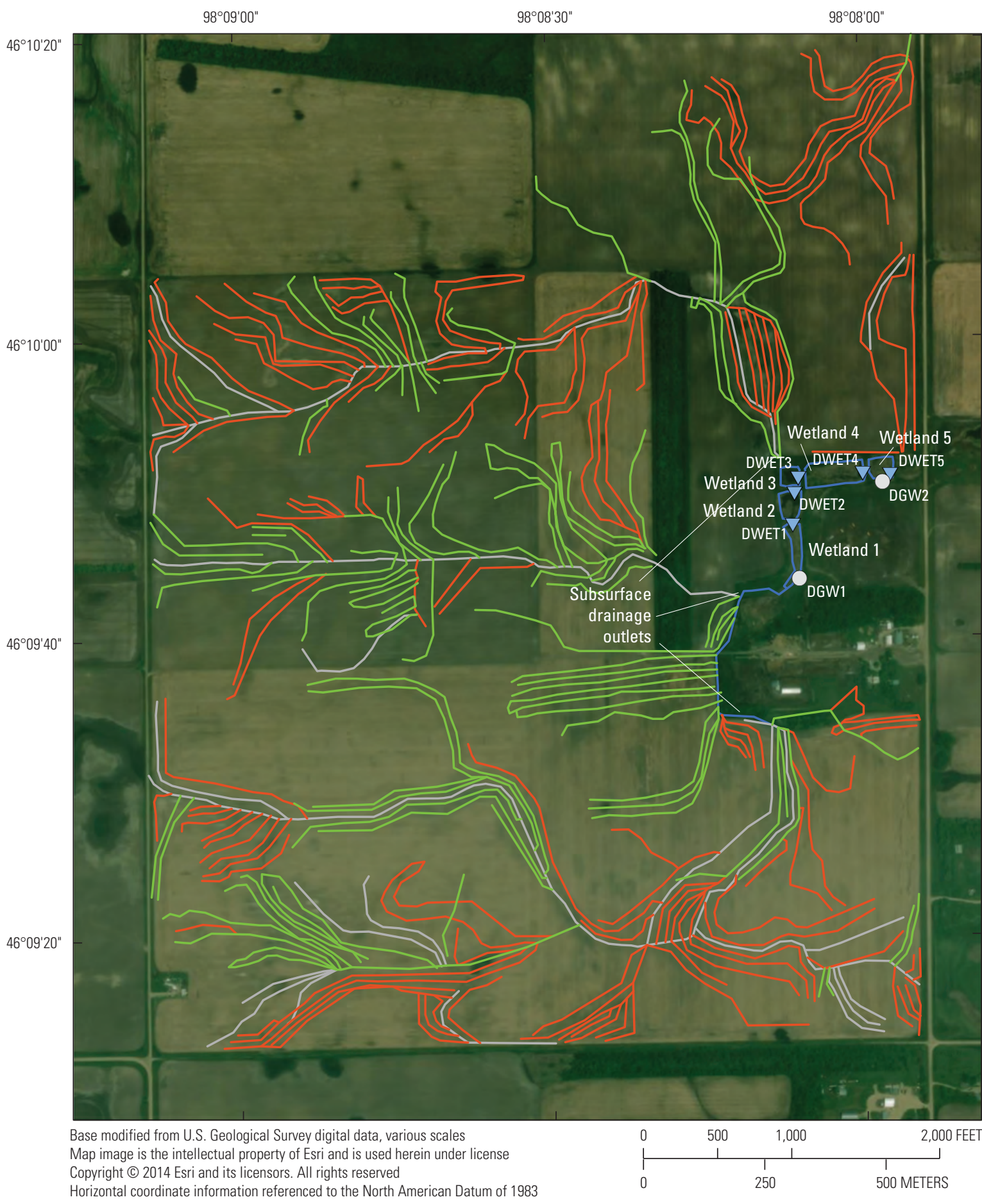

\section{EXPLANATION}

Subsurface drainage pipe, 4-inch diameter Subsurface drainage pipe, 8-inch diameter Subsurface drainage pipe, 10 -inch diameter Wetland boundary

Figure 4. Study area D in Dickey County, North Dakota.

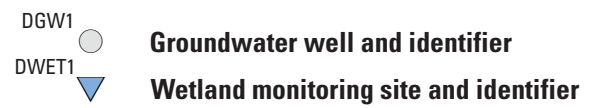


2009-10. Soils in the area were mostly loams including Barnes-Svea loam and Barnes-Buse soils (U.S. Department of Agriculture, 2020b).

Study area S in Sargent County is about 11 miles southeast of Oakes, N. Dak. (figs. 1 and 5). The study area contains a single wetland in the southwest portion of the study area, and the contributing surface drainage area determined using the USGS program StreamStats (U.S. Geological Survey, 2020b) is about 53 acres, all of which is subsurface drained fields (Jonathan Petersen, Natural Resources Conservation Services, written commun., 2019; fig. 5). The drainage system includes a simple array of 4-inch pipes that are about 2 to $3 \mathrm{ft}$ deep and connected to a 6-inch pipe that drains into a single outlet to the wetland (table 1; fig. 5). Crops planted in study area $\mathrm{S}$ were rotated between corn and soybeans during the modeling period (2003-18; U.S. Department of Agriculture, 2020a). Soils in the area were mostly loamy fine sands including Hecla-Garborg and Maddock soils (U.S. Department of Agriculture, 2020b).
In the three study areas, monitoring sites were installed for the development and calibration of the SPAW and DRAINMOD models for each study area. Water-level monitoring sites were installed at study area B in the four wetlands in 2018. Shallow groundwater wells also were installed in 2018 near wetlands 1 and 2 (fig. 3, table 2). At study area D, water-level monitoring sites were installed in the five wetlands and in two shallow groundwater wells that were installed in 2018 near wetlands 1 and 5 (fig. 4). A water-level monitoring site was installed in the wetland at study area $\mathrm{S}$ and in a shallow groundwater well that was installed near the wetland in 2018 (fig. 5). 


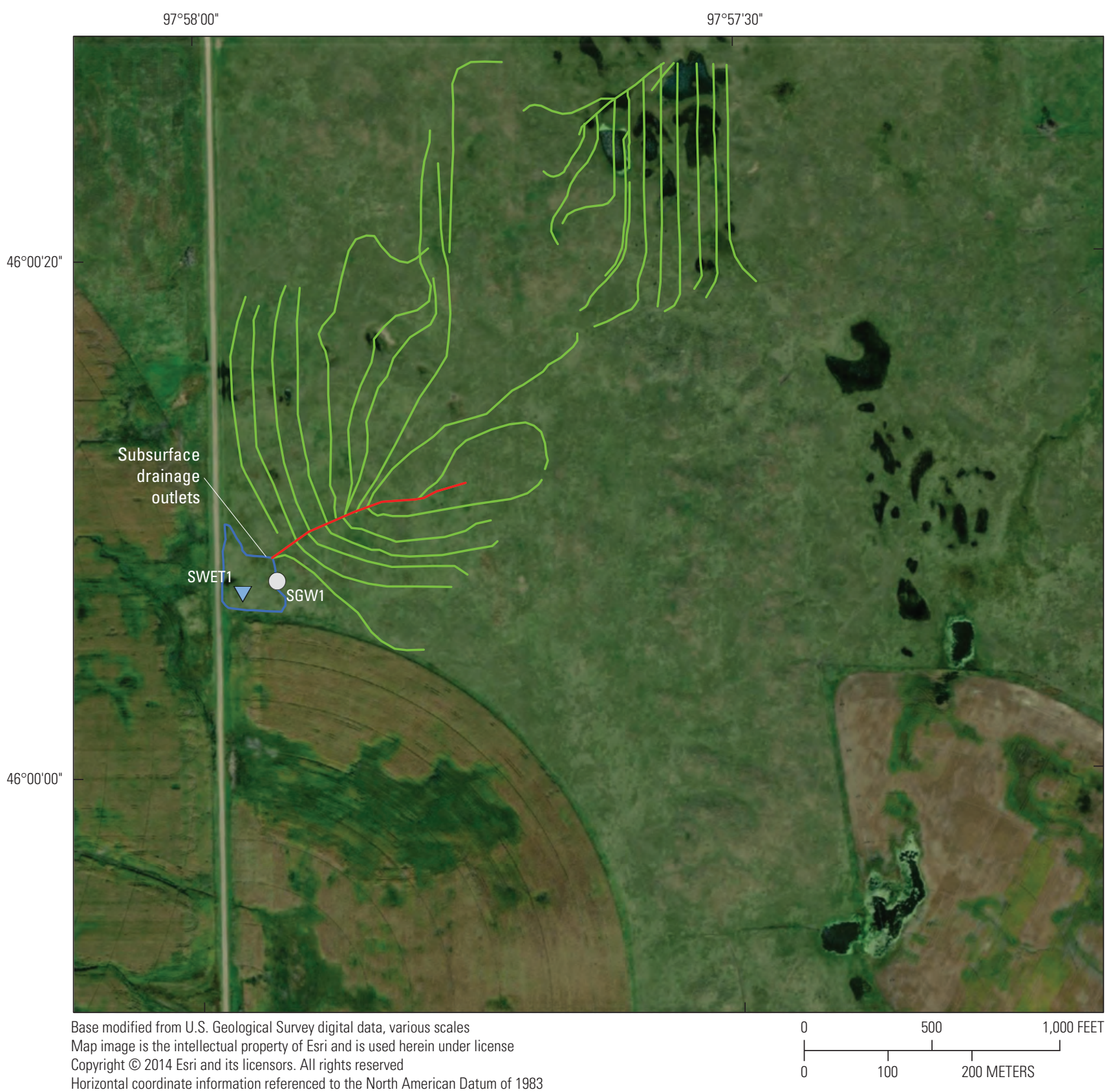

\section{EXPLANATION}

Subsurface drainage pipe, 4-inch diameter

- Subsurface drainage pipe, 6-inch diameter Wetland boundary $\begin{array}{ll}{ }_{\text {SGW1 }} \bigcirc & \text { Groundwater well and identifier } \\ { }^{S W E T 1} \nabla & \text { Wetland monitoring site and identifier }\end{array}$

Figure 5. Study area S in Sargent County, North Dakota. 
Table 2. Water-level and climate data collection sites used for SPAW and DRAINMOD model development and calibration for study areas B, D, and S.

[ND, North Dakota; WE, wetland; USGS, U.S. Geological Survey; GW, groundwater; CLI, climate; NDAWN, North Dakota Agricultural Weather Network; US, United States; NWS, National Weather Service]

\begin{tabular}{|c|c|c|c|c|c|c|c|}
\hline $\begin{array}{c}\text { Map } \\
\text { identification } \\
\text { number } \\
\text { (figs. 1, 3-5) }\end{array}$ & Site number & Site name & $\begin{array}{l}\text { Site } \\
\text { type }\end{array}$ & $\begin{array}{l}\text { Study } \\
\text { area }\end{array}$ & $\begin{array}{c}\text { Latitude, in } \\
\text { decimal degrees }\end{array}$ & $\begin{array}{c}\text { Longitude, in } \\
\text { decimal degrees }\end{array}$ & $\begin{array}{c}\text { Collecting } \\
\text { agency }^{1}\end{array}$ \\
\hline DWET1 & 460947098080601 & Wetland 1 northwest of Oakes, ND & WE & $\mathrm{D}$ & 46.16314 & -98.1352 & USGS \\
\hline DWET2 & 460949098080601 & Wetland 2 northwest of Oakes, ND & WE & $\mathrm{D}$ & 46.16372 & -98.1351 & USGS \\
\hline DWET3 & 460950098080601 & Wetland 3 northwest of Oakes, ND & WE & $\mathrm{D}$ & 46.16403 & -98.1350 & USGS \\
\hline DWET4 & 460950098075901 & Wetland 4 northwest of Oakes, ND & WE & $\mathrm{D}$ & 46.16411 & -98.1333 & USGS \\
\hline DWET5 & 460950098075702 & Wetland 5 northwest of Oakes, ND & WE & $\mathrm{D}$ & 46.16406 & -98.1326 & USGS \\
\hline DGW1 & 460943098080601 & 131-60-13ADD1 & GW & $\mathrm{D}$ & 46.16214 & -98.1350 & USGS \\
\hline DGW2 & 460950098075701 & 131-60-13ADA1 & GW & $\mathrm{D}$ & 46.16392 & -98.1328 & USGS \\
\hline BWET1 & 465443098042201 & Wetland 1 west of Valley City, ND & WE & $\mathrm{B}$ & 46.91219 & -98.0728 & USGS \\
\hline BWET2 & 465437098041601 & Wetland 2 west of Valley City, ND & WE & $\mathrm{B}$ & 46.91036 & -98.0713 & USGS \\
\hline BWET3 & 465437098041401 & Wetland 3 west of Valley City, ND & WE & $\mathrm{B}$ & 46.91050 & -98.0708 & USGS \\
\hline BWET4 & 465437098042301 & Wetland 4 west of Valley City, ND & WE & $\mathrm{B}$ & 46.91053 & -98.0732 & USGS \\
\hline BGW1 & 465437098041701 & $140-59-25 \mathrm{CAD} 1$ & GW & $\mathrm{B}$ & 46.91033 & -98.0716 & USGS \\
\hline BGW2 & 465444098042101 & 140-59-25CAB1 & GW & $\mathrm{B}$ & 46.91228 & -98.0728 & USGS \\
\hline SWET1 & 460007097575701 & Wetland 1 southeast of Oakes, ND & WE & $\mathrm{S}$ & 46.00194 & -97.9660 & USGS \\
\hline SGW1 & 460007097575501 & $129-58-09 \mathrm{BCC} 1$ & GW & $\mathrm{S}$ & 46.00208 & -97.9654 & USGS \\
\hline Precip1 & Dazey $2 \mathrm{E}$ & Dazey $2 \mathrm{E}$ & CLI & $\mathrm{B}$ & 47.18300 & -98.1380 & NDAWN \\
\hline Precip2 & Jamestown $10 \mathrm{~W}$ & Jamestown $10 \mathrm{~W}$ & CLI & $\mathrm{B}$ & 46.90600 & -98.9270 & NDAWN \\
\hline Precip3 & US1NDBR0002 & Valley City 2.0 NW, ND US & CLI & $\mathrm{B}$ & 46.94384 & -98.0358 & NWS \\
\hline Precip4 & Fingal 4W & Fingal 4W & CLI & $\mathrm{B}$ & 46.74600 & -97.9110 & NDAWN \\
\hline Precip5 & USC00325220 & Lisbon, ND US & CLI & $\mathrm{B}, \mathrm{D}, \mathrm{S}$ & 46.44440 & -97.6928 & NWS \\
\hline Precip6 & Lisbon 2W & Lisbon $2 \mathrm{~W}$ & CLI & $\mathrm{D}$ & 46.44477 & -97.7211 & NDAWN \\
\hline Precip7 & USC00325230 & Litchville 2 NW, ND US & CLI & $\mathrm{B}$ & 46.6612 & -98.2268 & NWS \\
\hline Precip8 & Oakes 4S & Oakes 4S & CLI & $\mathrm{D}, \mathrm{S}$ & 49.073734 & -98.0934 & NDAWN \\
\hline Precip9 & USC00326620 & Oakes, ND US & CLI & $\mathrm{S}$ & 46.145800 & -98.0919 & NWS \\
\hline Precip10 & USC00323117 & Forman 5 SSE, ND US & CLI & $\mathrm{S}$ & 46.033330 & -97.5950 & NWS \\
\hline Precip11 & Brampton 2WSW & Brampton 2WSW & CLI & $\mathrm{S}$ & 45.984106 & -97.8208 & NDAWN \\
\hline Precip12 & USC00324937 & LaMoure, ND US & CLI & $\mathrm{D}$ & 46.362500 & -98.2919 & NWS \\
\hline Precip13 & USC00323287 & Fullerton 1 ESE, ND US & CLI & $\mathrm{D}$ & 46.158330 & -98.3988 & NWS \\
\hline Precip14 & USC00391052 & Britton 13 NW, SD US & CLI & $\mathrm{S}$ & 45.921700 & -97.9330 & NWS \\
\hline
\end{tabular}

${ }^{1}$ USGS data available at U.S. Geological Survey (2020a); NDAWN data available at North Dakota Agricultural Weather Network (2019); NWS data available National Weather Service (2021). 


\section{Methods}

SPAW and DRAINMOD models were developed for three study areas in Barnes, Dickey, and Sargent Counties (study areas B, D, and S, respectively). Several datasets were used to develop models for each study area that included climate, soil, crop management, and hydrology data. The sources of data and methods used for model input, development, and calibration are described in this section.

\section{Model Input Data}

Inputs to the SPAW and DRAINMOD models were climate data, soil properties, crop variables, and site characteristics (for example, wetland properties and subsurface drainage configurations). For comparing simulated to measured water levels, continuous water-level data were collected at several sites in the wetlands and shallow groundwater wells in the three study areas from April 2018 through October 2018.

\section{Climate Data}

Climate data used in the SPAW and DRAINMOD models for the three study areas were obtained from the North Dakota Agricultural Weather Network (NDAWN; North Dakota Agricultural Weather Network, 2019) and the National Weather Service (NWS; National Weather Service, 2021). NDAWN data were the primary source of climate data. NWS data were used for precipitation in the winter (November through March) and to fill any data gaps that were in the NDAWN data periods of record. Precipitation data are not collected at NDAWN sites during the winter. NDAWN and NWS sites used for developing input datasets are shown on figure 1 and listed in table 2. The NWS site near Lisbon, N. Dak. (climate site precip5; fig. 1), was used to estimate winter data for all three study areas because climate site precip 5 was the closest site with available winter precipitation data.

Climate data included air temperature, potential evapotranspiration (ET), and precipitation. Daily minimum and maximum air temperature, potential ET, and precipitation were used for input to the SPAW model. Hourly precipitation and daily minimum and maximum air temperature data were used as input for the DRAINMOD model. Because weather sites were not directly adjacent to the three study areas, data from multiple sites were combined for use in the SPAW models at each study area using an inverse distance weighted value $\left(X_{p}\right)$ described in equation 1 :

$$
X p=\frac{\frac{1}{d i^{2}}}{\sum_{i=1}^{n} \frac{1}{d i^{2}}}
$$

where

$$
\begin{aligned}
& X_{p} \quad \text { is the inverse-distance weight applied to each } \\
& \text { climate site to estimate data at each study } \\
& \text { area, and } \\
& d_{i} \quad \text { is distance of the climate site from study area, } \\
& \text { in miles. }
\end{aligned}
$$

The daily climate data at sites used for each study area were multiplied by the inverse-distance weight and then summed to estimate the data for each study area. Sites used for SPAW model input at each study area and weighting coefficients used for the data at each site to determine the values used are provided in table 3. For the DRAINMOD models in each study area, hourly precipitation was required for the models, and a single site closest to the study areas was used. For study area B, the hourly precipitation and daily temperatures (maximum and minimum) from climate sites precip1, precip2, and precip4 were used; and, for study areas D and S, data from climate site precip8 were used for input into the model (fig. 1; table 2).

The SPAW and DRAINMOD models provide options for inputs of potential ET in the model simulations. For DRAINMOD, if daily potential ET is available from a site, ET can be input directly or can be computed within the model using input of measured daily minimum and maximum air temperature. The internal computation of potential ET was used in the DRAINMOD model applications for the three study areas because of incomplete potential ET data available at the climate sites in the area. Similarly, for the SPAW model, daily potential ET from a site either can be input directly as a daily value to the model, or an annual potential ET can be used, and the model internally estimates daily potential ET from the annual value. At each study area, total annual ET data from the nearest site with available data for multiple years were computed for input to SPAW, and daily estimates were determined in the model. For study area B, potential ET data from climate site precip1 were used; and, for study areas D and S, data from climate site precip8 were used to compute annual potential ET.

\section{Crop Data}

SPAW uses data on the spatial distribution of crops to simulate the hydrology at the surface and in the subsurface. Crop data were obtained from the U.S. Department of Agriculture CropScape database (U.S. Department of Agriculture, 2020a). CropScape provides annual crop-specific land cover data for the continental United States produced by satellite imagery that has been checked with ground truthing. The geospatial data is georeferenced and provided in a raster format. Data were obtained for fields used in simulations in SPAW models developed for each study area. 
Table 3. Climate sites and inverse-distance weights used for estimating climate data for SPAW models at study areas B, D, and S, 2003-18.

\begin{tabular}{llcc}
\hline \multicolumn{1}{c}{$\begin{array}{c}\text { Map } \\
\text { identification } \\
\text { number } \\
\text { (fig. 1) }\end{array}$} & Site number & \multicolumn{1}{c}{$\begin{array}{c}\text { Distance from } \\
\text { study area, } \\
\text { in miles }\end{array}$} & Weight \\
\hline Precip1 & \multicolumn{1}{c}{ Study area B } & & 0.028 \\
Precip3 & Dazey 2E & 19.5 & 0.880 \\
Precip4 & US1NDBR0002 & 3.5 & 0.058 \\
Precip7 & Fingal 4W & 13.6 & 0.033 \\
\hline & USC00325230 & 18 & 0.030 \\
\hline Precip5 & \multicolumn{1}{c}{ Study area D } & 0.034 \\
Precip6 & USC00325220 & 30 & 0.638 \\
Precip8 & Lisbon 2W & 28 & 0.111 \\
Precip12 & Oakes 4S & 6.5 & 0.187 \\
Precip13 & USC00324937 & 15.6 & \\
\hline & USC00323287 & 12 & 0.213 \\
\hline Precip8 & \multicolumn{1}{c}{ Study area S } & 7.8 & 0.097 \\
Precip9 & Oakes 4S & 11.53 & 0.039 \\
Precip10 & USC00326620 & 18.2 & 0.255 \\
Precip11 & USC00323117 & 7.12 & 0.396 \\
Precip14 & Brampton 2WSW & 5.72 & \\
\hline
\end{tabular}

\section{Soil Data}

SPAW and DRAINMOD models use a variety of soil properties to simulate the hydrology in the surface and subsurface. Soil data were obtained from the NRCS Web Soil Survey website (U.S. Department of Agriculture, 2020b). The Web Soil Survey provides spatial soil data and information produced by the National Cooperative Soil Survey. The National Cooperative Soil Survey Soil Characterization Database contains reports of soil characterization data from the National Soil Survey Center, Kellogg Soil Survey Laboratory, and cooperating laboratories (National Cooperative Soil Survey, 2019). The most dominant soil present for each study area was selected from the Web Soil Survey, and soil property data for the selected soils were obtained from National Cooperative Soil Survey (2019) to develop parameters for use in the SPAW and DRAINMOD simulations. For the pond model within the SPAW simulations, the dominant soil type in the wetland area was used to determine the wetland bottom properties.

For simulations in DRAINMOD, a single soil type was used for the models in each study area, and the dominant soil type was selected to determine model parameters. Soil parameters used in DRAINMOD were estimated using another program to process the soil data from the NRCS Web Soil Survey website (U.S. Department of Agriculture, 2020b). A computer program, ROSETTA (version 1.2; Schaap and others, 2001), was used to estimate several unsaturated hydraulic properties needed for simulations in DRAINMOD from the soils data. The estimated properties were residual water content, saturated water content, curve parameter alpha, curve parameter $\mathrm{n}$, saturated hydraulic conductivity, and matching point at saturation. ROSETTA is a computer program that uses five, hierarchal pedotransfer functions to estimate unsaturated hydraulic properties from surrogate soil data such as using limited (textural classes only) to more extended (texture, bulk density, and one or two water retention points) input data (Schaap and others, 2001). A pedotransfer function generally refers to translating raw soil data into more useful information, such as converting soil data into hydraulic properties. The program can be used to estimate water retention, saturated hydraulic conductivity, and unsaturated hydraulic conductivity parameters according to van Genuchten (1980) and Mualem (1976). ROSETTA uses one of the following hierarchical sequences of input data to select which model to use: (1) soil textural class; (2) sand, silt, and clay percentages; (3) sand, silt, and clay percentages and bulk density; (4) sand, silt, and clay percentages, bulk density, and a water retention point at 130 inches (4.8 pounds per square inch); or (5) sand, silt, and clay percentages, bulk density, and water retention points at 130 and 5,906 inches (4.8 and 218 pounds per square inch, respectively). Water retention points come from a water retention curve that is developed from the relation between the water content (the quantity of water within a material) and the soil water potential (the potential energy or tendency of water 
to move from one area to another because of a given stress such as osmosis, gravity, or capillary action). The first model is based on a lookup table that provides class mean hydraulic parameters for each soil textural class, whereas the other four models are based on neural network analyses and provide more accurate predictions when more input variables are used. Soils data were imported into ROSETTA and processed. The resulting outputs were loaded into DRAINMOD as inputs.

\section{Depth-Capacity Curves and Elevation Data}

An input to the SPAW model for determining volume change in the pond model portion of SPAW is a depth-capacity curve for each wetland modeled. Depth-capacity curves were estimated from light detection and ranging (lidar) data obtained from the North Dakota State Water Commission (2019). In study area S, the downloaded lidar data and field survey data were used to generate the depth-capacity curve for the wetland. A computer program called Surfer (version 17; Golden Software, 2019) was used to generate grid layers from data that consists of lidar data points and surveyed elevation points that would show the layer shape of a wetland. Each wetland layer was run through a volume calculation function within Surfer to calculate the area under a constant value. The constant in the calculation would be a hypothetical water-surface elevation, and the calculated area would be 'how much' water would be within the wetland. To develop a depth-capacity curve for the models, many calculations would need to be run. A simple script was set up using Golden Software's Scripter (version 5) to automate the calculation process (Golden Software, 2019). Elevation values would start a few feet below the wetland layer and would increase $0.01 \mathrm{ft}$ each calculation until the wetland layer was below the water surface.

Measured elevation data were collected using surveygrade Global Navigation Satellite Systems (GNSS) methods (Rydlund and Densmore, 2012). Vertical control was obtained by checking against National Geodetic Survey markers in the local area. Real-time GNSS data were collected using a single-base real-time kinematic surveying approach described in Rydlund and Densmore (2012). A dual-frequency receiver base station was mounted on a fixed-height tripod directly over a known benchmark. The base station included a broadcast radio and long whip antenna that were used to broadcast data corrections from the base receiver to a rover receiver (Rydlund and Densmore, 2012). Several factors affect the vertical accuracy of the data corrections from the base in "real time" to derive position and elevation of an objective GNSS survey, including current satellite geometry and various other factors (for example, multipath errors and signal degradation from vegetation cover) interfering with the base-to-rover communication. Single-base real-time kinematic equipment vertical accuracies, assuming a minimum of five satellites and position dilution of precision less than 4 , are generally $0.066 \mathrm{ft}$ plus or minus 1 part per million at the 68 -percent confidence level (Rydlund and Densmore, 2012). Elevation verification shots were collected during each survey on at least two National Geodetic Survey markers.

In addition to land surface and wetland elevations, GNSS surveys were used to determine reference points for water-level measurement sites for water levels in the wetlands and shallow groundwater wells (figs. 3-5, table 2). At each measurement site, a reference point was established to verify the recorded data such as the measurement point at the top of the shallow groundwater wells and the pin on the installation of the water-level sites in the wetlands. The reference points were surveyed at the beginning of the monitoring period in April 2018 and at the end of the monitoring period in October 2018.

\section{Measured Water-Level Data}

Water-level data in wetlands and shallow groundwater wells at each site were continuously measured from about April 26, 2018 through October 28, 2018, for comparison to simulated water table depths (DRAINMOD) and water levels in the wetlands (SPAW) in each study area. Water-level data were recorded every hour using data logging pressure transducers. Data were downloaded from the data loggers periodically and uploaded into the USGS National Water Information System (NWIS) database for processing. Processing included correcting recorded data to reference point measurements and removal of any erroneous data. For example, during several periods, the groundwater well in study area $\mathrm{S}$ (SGW1; fig. 5) went dry; therefore, the sensor was not in the water and the data were removed. Water-level data were referenced to the North American Vertical Datum of 1988 by establishing a reference point that was surveyed using survey grade GNSS methods. Collected data were processed following USGS procedures (Valder and others, 2018; Cunningham and Schalk, 2011). Water-level data were stored and can be accessed through the USGS NWIS database (U.S. Geological Survey, 2020a) by using the site numbers in table 2 .

At study area B, water-level sensors were installed and operated at four wetland locations (BWET1, BWET2, BWET3, and BWET4) and two shallow groundwater wells (BGW1 and BGW2; fig. 3; table 2). At study area D, waterlevel sensors were installed and operated at five wetlands (DWET1, DWET2, DWET3, DWET4, and DWET5) and two shallow groundwater wells (DGW1 and DGW2; fig. 4). At study area $\mathrm{S}$, water-level sensors were installed and operated at one wetland location (SWET1) and one shallow groundwater well (SGW1; fig. 5).

\section{Model Implementation}

The SPAW model simulates the daily hydrologic water budgets of agricultural landscapes by two linked routines, one for farm fields (field hydrology) and one for impoundments such as wetlands and ponds (pond model; Saxton and Willey, 
2004). Field hydrology is represented by precipitation; temperature; ET; interacting soil layers (each layer with unique water holding characteristics); and annual crop growth with management options for rotations, irrigation, and fertilization. Simulations estimate daily vertical, one-dimensional water budget with soil-water profiles of all primary hydrologic processes such as runoff, infiltration, storage, and seepage to groundwater. Pond hydrology simulations provide water budgets by multiple inflow and outflow processes for impoundments that have agricultural fields or operations as a water source (Saxton and Willey, 2004).

The DRAINMOD model was used in conjunction with the SPAW model because although the SPAW model can be used to simulate the hydrology of small drainage basins containing wetlands, the SPAW model does not contain routines to simulate drainage, either subsurface drainage or surface (drainage ditches), that can directly affect the wetland hydrology. The wetlands in the study areas in this report are all downstream from and adjacent to drained agricultural fields. The DRAINMOD model (Skaggs, 1978, 1980) is based on a water balance in the soil profile and uses climatological records to simulate the performance of drainage and water table control systems. The model was developed specifically for shallow water table soils. The model has typically been applied to field-sized units (about 250 acres or more) drained by parallel subsurface drains or ditches. The more uniform the drainage configuration, the larger the field size that can be simulated.

The SPAW and DRAINMOD models were developed for the conditions at three study areas in Barnes (study area B), Dickey (study area D), and Sargent (study area S) Counties in North Dakota. Conditions were simulated for the period of January 1, 2003, through December 31, 2018, at all three study areas. Although measured data were only collected in 2018 for calibration, the long simulation period was chosen based on the availability of climate data to evaluate simulations throughout a wide range of hydrologic and climatic conditions and to allow a sufficient "warm-up" period for the models.

\section{SPAW}

The SPAW model was implemented to simulate hydrologic conditions at the three study areas in North Dakota (study areas B, D, and S) from January 1, 2003, through December 31, 2018. Implementation included the delineation of modeled fields, preliminary selection of model parameters, and specification of boundary and initial conditions. Model results were compared to measured data collected from April 2018 through October 2018. Assumptions associated with the implementation and development of the SPAW model for each of the three study areas are described in this section.

The SPAW field hydrology model (field model) uses different methods to quantify the daily hydrologic conditions in an agricultural field such as surface runoff, soil water content, actual ET, plant water stress, and deep infiltration through the soil profile (fig. 6). Redistribution of the infiltrated water throughout the soil profile is done using the Darcy equation for unsaturated soil water flow that provides for upward and downward flow components (Saxton, 2002). Model inputs include climate data, soil properties, and crop management properties in a one-dimensional vertical plane. Climate data inputs include precipitation, potential ET, and air temperature. Snowfall data are not explicitly input in the model but are simulated using precipitation and air temperature data. Soil property inputs include the depth and thickness, soil composition, hydrologic soil group, and if applicable, groundwater information. Crop management includes the crop rotation and the specific crop properties.

The SPAW model also has a module for simulating the water balance for waterbodies such as a pond, wetland, or other types of impoundments (pond model; fig. 7). The pond model uses input depth-capacity tables to simulate changing depth with changing volume from various inflows and outflows included in the model. Inflows to the pond model can include input from runoff and infiltration from the field hydrology model, direct runoff, precipitation, inflow from other waterbodies, seepage from groundwater, and pumped inflows. Outflows from the pond model include evaporation, infiltration, seepage, outlet pipes and spillways, and various pumped outflows.

Other applications of the SPAW model have been used to assist with construction of a wetland for detention of agricultural runoff from a 400-acre drainage basin in Louisiana (Millhollon and others, 2009), estimate the effectiveness of vegetation treatments for feedlot runoff in Iowa (Andersen and others, 2010), evaluate land-management treatments on the hydrology of a wetland in Tennessee (Hill and Neary, 2009), and estimate the water balance for an irrigation storage pond in Ghana (Debre and others, 2011).

\section{Delineation of Modeled Fields}

Multiple modeled fields were used for the SPAW field simulation model to account for the heterogeneity of soil type and crop rotation in the study areas. The drainage basin delineation tool in StreamStats (U.S. Geological Survey, 2020b), a USGS streamflow statistics and spatial analysis tool, was used to identify the contributing area to the wetlands in the three study areas. Agricultural fields with similar crop rotations determined from CropScape (U.S. Department of Agriculture, 2020a) were then grouped together within the contributing area to delineate the model fields at each study area (fig. 8A-C; table 4). The dominant soil units determined from the NRCS Web Soil Survey (U.S. Department of Agriculture, 2020b) were used as the soil input for SPAW in each model field.

For study area B, the SPAW field simulation model included five field hydrology model fields that were input into the pond simulation model for the wetlands in the study area (fig. 8A). Study area D included six model fields in the field simulation model for input into the pond simulation for the wetlands in the study area (fig. $8 B$ ). Study area $\mathrm{S}$ was modeled 


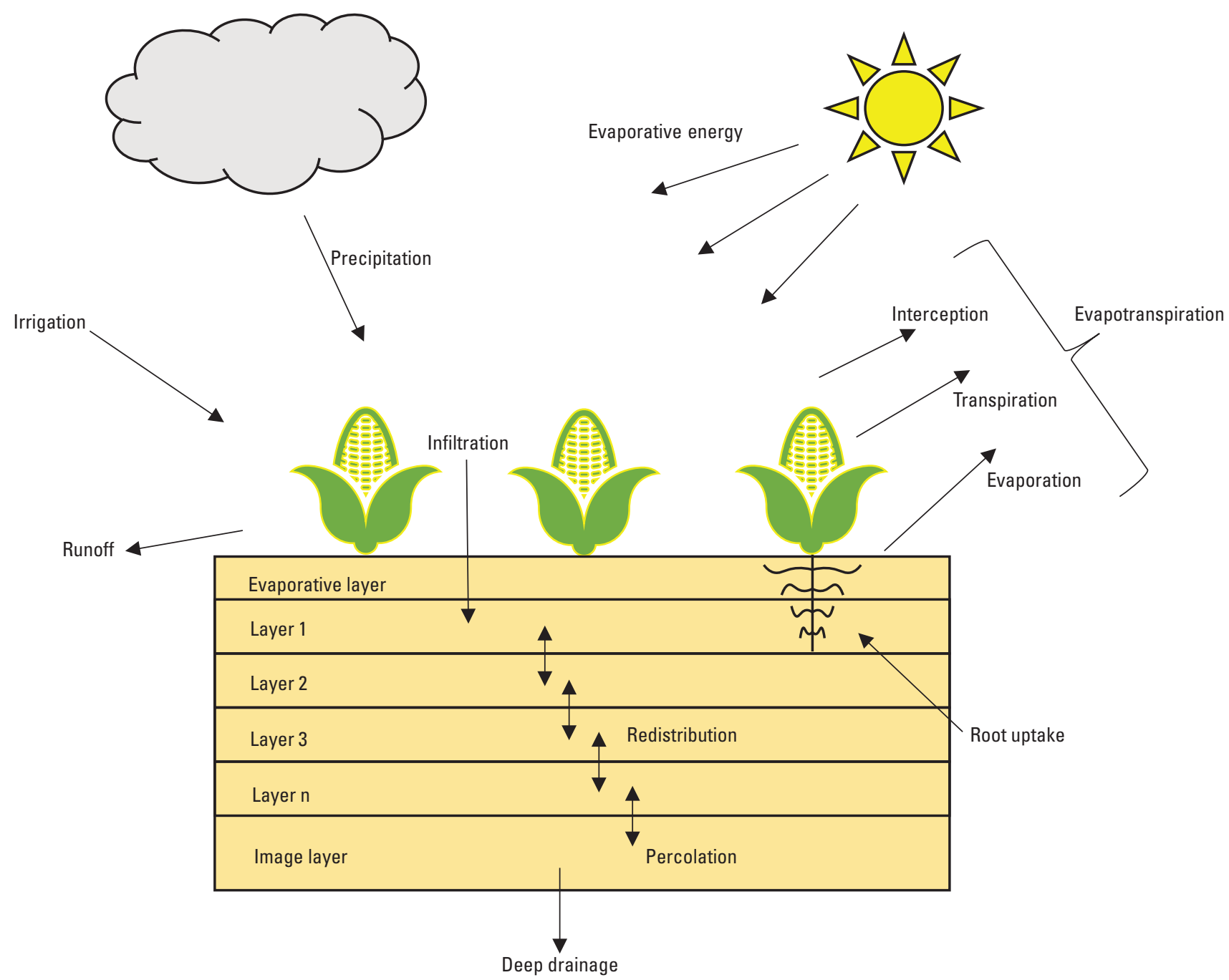

Figure 6. Conceptual diagram of processes simulated in the field hydrology model within the SPAW model. Modified from Saxton and Willey (2004).

using only one model field for the field simulation because of the small size of the contributing area that drains into the wetland (fig. 8C).

\section{Model Parameters}

The SPAW field hydrology and pond models use many model parameters to describe the physical processes of the agricultural hydrology of each study area. Many of the model parameters could not be directly measured and were adjusted within a plausible range during the model calibration until the simulated values agreed with the measured values. Some of the coefficients were based on default values within the SPAW model, and other coefficients were based on the hydrologic and climatic conditions at each site (Saxton and Willey, 2004).
For field hydrology simulations in SPAW, modeled fields were delineated based on the crop rotation in the drainage area throughout the simulation period (fig. 8; table 5). For most crop-related parameters applied to each of the fields, the default values in SPAW for various crop types such as corn, soybeans, spring wheat, and pasture with warm season grasses were used for simulating processes such as moisture uptake, interception, transpiration, and evaporation at the land surface (table 5). Several properties varied with time throughout the growing season such as plant date, harvest date, canopy cover, greenness, and root depths. Root depth can change on an annual basis and affect the ET from plants, but these data are generally not well known; therefore, default values were used in the model to simulate the annual variations in root zone depths. Monthly values for these parameters were input and were consistent throughout the simulation period (2003-18) for each of the crop types. 


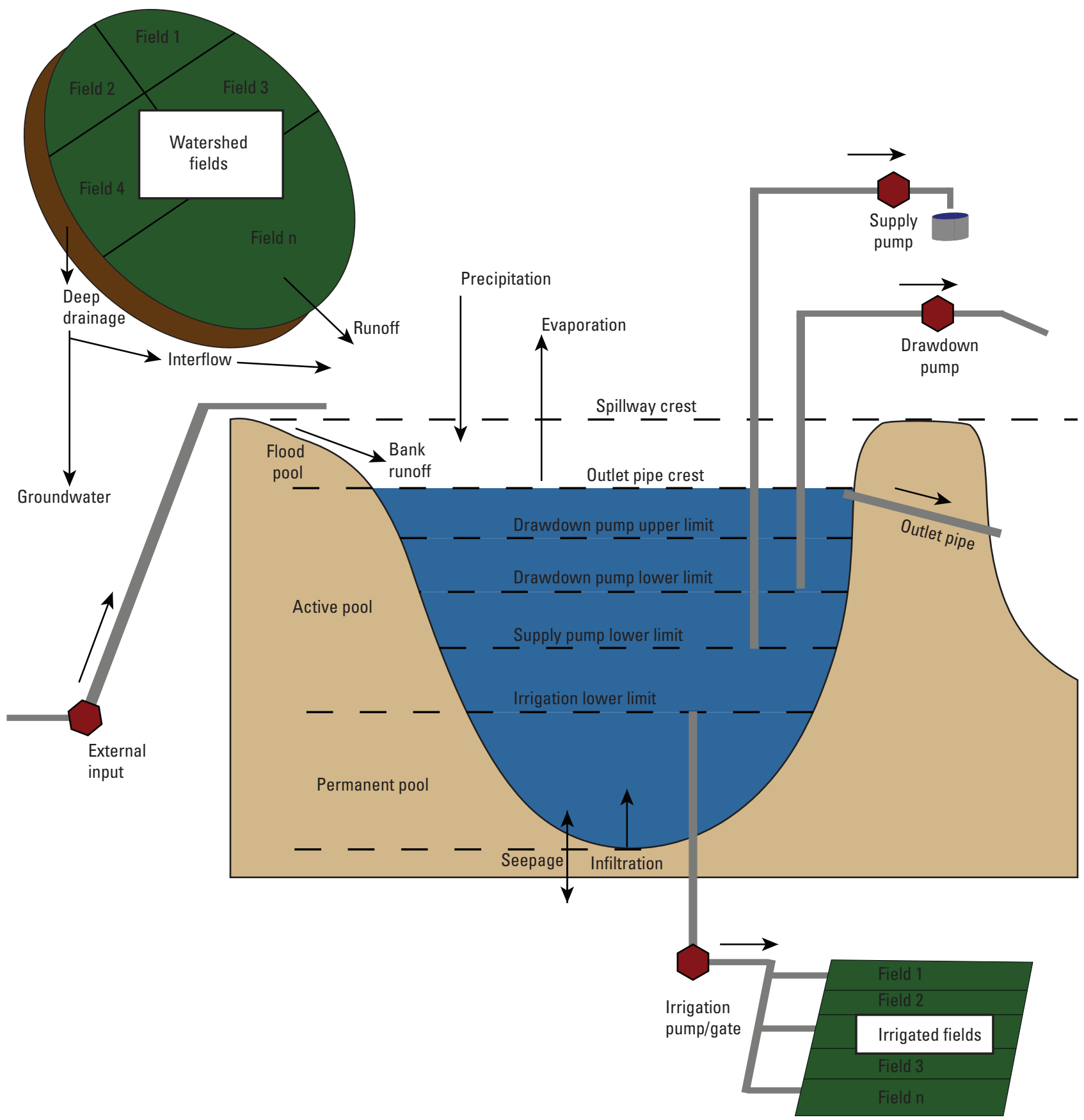

Figure 7. Conceptual diagram of processes simulated in the pond hydrology model within the SPAW model. Modified from Saxton and Willey (2004).

Soil properties such as percent weight of sand, clay, gravel, organic matter, and bulk density for each soil layer were input to every model field in the field hydrology model of each SPAW model (appendix tables 1.1 through 1.3). Parameters for determining processes such as runoff and infiltration are computed internally in SPAW based on the input soil properties. Other parameters were input to the field hydrology model in SPAW to control processes such as snow melt, soil freeze, evaporation, and boundary conditions (table 6).
The pond model simulations in SPAW require input of depth-capacity curves and parameters that define inflows and outflows to all simulated waterbodies. Although several wetlands were in study area B, the wetlands were treated as one waterbody in the model because the wetlands were often connected during the period when water levels were measured (April 2018 through October 2018). Therefore, a single depthcapacity curve was used in the model (appendix table 1.4) for 


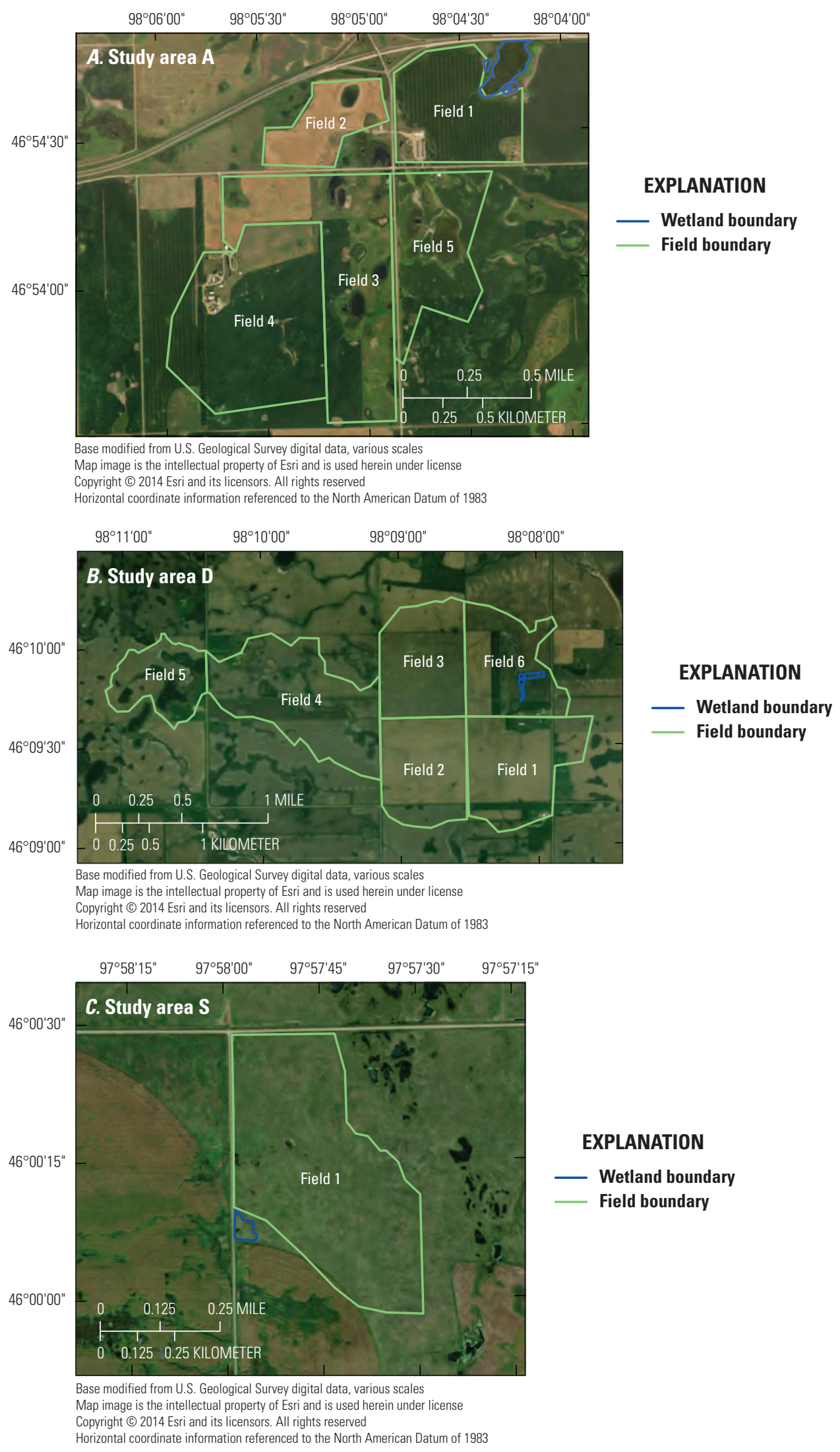

Figure 8. Model fields used in SPAW models developed for three study areas. $A$, study area $B ; B$, study area $D$; and $C$, study area $S$. 
Table 4. Crop data used for fields in SPAW models developed for study areas B, D, and S, 2003-18.

$[\mathrm{SB}$, soybeans; SW, spring wheat $]$

\begin{tabular}{|c|c|c|c|c|c|c|c|c|c|c|c|c|}
\hline \multirow{3}{*}{ Year } & \multicolumn{5}{|c|}{ Study area B } & \multicolumn{6}{|c|}{ Study area D } & \multirow{3}{*}{$\begin{array}{c}\text { Study area } \mathbf{S} \\
\text { Field } 1\end{array}$} \\
\hline & \multicolumn{5}{|c|}{ Field } & \multicolumn{6}{|c|}{ Field } & \\
\hline & 1 & 2 & 3 & 4 & 5 & 1 & 2 & 3 & 4 & 5 & 6 & \\
\hline 2003 & SB & SW & SW & Corn & Pasture & SB & SB & Corn & Corn & SB & SB & SB \\
\hline 2004 & SW & Corn & SW & SB & Pasture & Corn & Corn & SB & SB & Corn & Bare soil & Corn \\
\hline 2005 & Corn & SB & SB & SW & Pasture & SB & SB & Corn & Corn & SB & Bare soil & SB \\
\hline 2006 & SB & SW & SW & Corn & Pasture & Corn & Corn & SB & SB & Corn & Bare soil & Corn \\
\hline 2007 & Corn & SW & Corn & SB & Pasture & SB & SB & Corn & Corn & SB & SB & SB \\
\hline 2008 & SB & Corn & SB & SW & Pasture & Corn & Corn & SB & SB & Corn & Corn & Corn \\
\hline 2009 & SW & SB & SW & Corn & Pasture & SB & SB & Corn & Corn & SB & Pasture & SB \\
\hline 2010 & Corn & SW & Corn & SB & Pasture & Corn & Corn & SB & SB & Corn & Pasture & Corn \\
\hline 2011 & SB & Corn & SB & Corn & Pasture & SB & SB & Corn & Corn & SB & SB & SB \\
\hline 2012 & Corn & SB & Corn & SB & Pasture & Corn & Corn & SB & SB & Corn & Corn & Corn \\
\hline 2013 & SB & SW & SB & Corn & Pasture & SB & SB & Corn & Corn & SB & SB & SB \\
\hline 2014 & SW & Corn & SW & SB & Pasture & Corn & Corn & SB & SB & Corn & SB & Corn \\
\hline 2015 & Corn & SB & SB & SW & Pasture & SB & SB & Corn & Corn & SB & Corn & SB \\
\hline 2016 & SB & SW & Corn & SB & Pasture & Corn & Corn & SB & SB & Corn & SB & Corn \\
\hline 2017 & Corn & SB & SB & SW & Pasture & SB & SB & Corn & Corn & SB & Corn & SB \\
\hline 2018 & SB & SW & SW & SB & Pasture & Corn & Corn & SB & SB & Corn & SB & Corn \\
\hline
\end{tabular}

Table 5. Parameters used for crop types in the field hydrology model portion of the SPAW model for study areas B, D, and S, 2003-18.

$[--$, no data $]$

\begin{tabular}{|c|c|c|c|c|}
\hline Parameter & Corn & Soybeans & Spring wheat & $\begin{array}{l}\text { Pasture-warm } \\
\text { season grass }\end{array}$ \\
\hline Plant date & May 10 & May 25 & April 15 & -- \\
\hline Canopy surface, in inches & 0.1 & 0.05 & 0.1 & 0.1 \\
\hline Soil surface, in inches & 0.05 & 0.05 & 0.05 & 0.05 \\
\hline Hydrologic condition & Good & Good & Good & Good \\
\hline Canopy cover curve, in percent & 5 to 95 & 15 to 95 & 0 to 94 & 60 to 95 \\
\hline Greenness curve, in percent & 0 to 100 & 0 to 95 & 0 to 100 & 0 to 100 \\
\hline Root depth curve, in inches & 0 to 60 & 0 to 48 & 0 to 40 & 36 \\
\hline
\end{tabular}

study area B. At study area D, five wetlands were simulated in SPAW, and at study area S only one wetland was simulated in SPAW (appendix tables 1.5 and 1.6, respectively).

Inflow computed within the pond model from input precipitation and air temperature data included bank runoff, direct precipitation, and evaporation. Inflow generated from the field hydrology models through runoff and interflow also were linked to the pond model. Inflow from subsurface drainage outflow generated from DRAINMOD simulations also was added as an external input to the wetlands at each study area. Although DRAINMOD produces daily values of drainage outflow, SPAW only allows a set value for defined periods to be input, so monthly mean inflows were computed from the DRAINMOD output and used in the SPAW simulations (appendix table 1.8). 
Table 6. Parameters used for the field hydrology model portion of the SPAW model for study areas B, D, and S, 2003-18.

\begin{tabular}{|c|c|c|c|c|c|c|c|c|c|c|c|c|}
\hline \multirow{3}{*}{ Parameter } & \multicolumn{5}{|c|}{ Study area B } & \multicolumn{6}{|c|}{ Study area D } & \multirow{3}{*}{$\begin{array}{c}\text { Study area S } \\
\text { Field } 1\end{array}$} \\
\hline & \multicolumn{5}{|c|}{ Field } & \multicolumn{6}{|c|}{ Field } & \\
\hline & 1 & 2 & 3 & 4 & 5 & 1 & 2 & 3 & 4 & 5 & 6 & \\
\hline Snow accumulation temperature, degrees Celsius & 0 & 0 & 0 & 0 & 0 & 0 & 0 & 0 & 0 & 0 & 0 & 0 \\
\hline Snow melt temperature, degrees Celsius & 0.6 & 0.6 & 0.6 & 0.6 & 0.6 & 0.6 & 0.6 & 0.6 & 0.6 & 0.6 & 0.6 & 0.6 \\
\hline Snow melt rate factor, dimensionless & 4.00 & 4.00 & 4.00 & 4.00 & 4.00 & 4.00 & 4.00 & 4.00 & 4.00 & 4.00 & 4.00 & 4.00 \\
\hline Soil freezing factor, dimensionless & 0.97 & 0.97 & 0.97 & 0.97 & 0.97 & 0.97 & 0.97 & 0.97 & 0.97 & 0.97 & 0.97 & 0.97 \\
\hline Soil water evaporation conductivity, in percent & 5 & 5 & 5 & 10 & 5 & 10 & 5 & 5 & 5 & 5 & 10 & 5 \\
\hline $\begin{array}{l}\text { Percent image layer field capacity before down- } \\
\text { ward drainage }\end{array}$ & 90 & 100 & 100 & 100 & 100 & 100 & 100 & 100 & 100 & 100 & 100 & 100 \\
\hline Water table depth, in inches & -- & -- & -- & -- & -- & -- & -- & -- & -- & -- & -- & 27.8 \\
\hline $\begin{array}{l}\text { Maximum image layer flow rate, in inches per } \\
\text { day }\end{array}$ & 5 & 5 & 5 & 5 & 5 & 5 & 1 & 1 & 1 & 1 & 5 & 5 \\
\hline Annual evapotranspiration, in inches & 56.6 & 56.6 & 56.6 & 56.6 & 56.6 & 42.3 & 42.3 & 42.3 & 42.3 & 42.3 & 42.3 & 53.25 \\
\hline Total contributing area per field, in acres & 119.9 & 64.8 & 216.5 & 236.3 & 211.4 & 232 & 193 & 204 & 313 & 128 & 194 & 53 \\
\hline
\end{tabular}


There are several options for outflow structures and pumps in the pond model in SPAW such as outflow pipes, weirs, and pumped flow (fig. 7). No outflow structures or pumps affected the wetlands at all three wetlands; therefore, a simple spillway or weir was used to simulate outflow from the wetlands when they reached a defined water level (except for the wetlands at study area D; table 7). For the pond model at study area B, the wetlands were treated as a single wetland and a weir function was implemented to simulate the natural outflow from the wetland. Other than inflow from the field model and precipitation, the only external inflow included in the model was outflow from the subsurface drainage system, which was estimated from simulated results of the DRAINMOD model for the area. Study area S only included one wetland in the pond model, and a weir function was implemented to simulate the natural outflow. The pond model included inflow from subsurface drainage from simulated results of the DRAINMOD model.

Five wetlands were simulated at study area D that are connected in series by culvert structures (fig. 4). Discharge through the culverts were estimated as peak discharges when the wetlands were at maximum water levels using methods described in Carter (1957). The survey data collected using GNSS methods were used to determine the lengths, diameters, and slopes of the culverts. The peak discharges ranged from 12 to 48 cubic feet per second (appendix table 1.7). Carter (1957) described that type five (inlet is submerged, and outlet is not submerged) or type six (inlet and outlet are submerged) flows will occur if equation 2 is satisfied.

$$
\frac{(h 1-z)}{D}<2
$$

where

$$
\begin{aligned}
& h_{1} \quad \text { is the water height above the datum (lowest } \\
& \text { culvert elevation) upstream of the } \\
& \text { culvert, in feet; } \\
& \text { is distance between the culvert bottoms of } \\
& \text { the upstream and downstream ends, in } \\
& \text { feet; and }
\end{aligned}
$$

Manning's equation (Chow, 1959) was used to determine the discharge from wetland 3 into wetland 4 (fig. 4) because the culvert was washed out before the monitoring period and is now a channel. A rectangular channel was assumed with a width of $3.5 \mathrm{ft}$ and a Manning's roughness coefficient of 0.08 (Chow, 1959; table 1.7). The maximum height of water for the channel between wetlands 3 and 4 was assumed to be $3.26 \mathrm{ft}$.

Other processes in the water budget in the pond models in SPAW included infiltration (outflow) and seepage (inflow or outflow; table 7). The seepage rate on the pond bottom was a parameter that was determined using measured water-level data from the ponds during April 2018 through October 2018 and soil properties from the NRCS Web Soil Survey (U.S. Department of Agriculture, 2020b). Seepage was estimated from horizontal hydraulic conductivity data using the assumption that the vertical hydraulic conductivity is about 10 percent of the horizontal hydraulic conductivity (Freeze and Cherry, 1979). Although the seepage rate out of the pond

\begin{tabular}{|c|c|c|c|c|c|c|c|}
\hline \multirow{3}{*}{ Parameter } & \multicolumn{7}{|c|}{ Study area } \\
\hline & B & & & D & & & $\mathbf{S}$ \\
\hline & Pond 1 & \multicolumn{5}{|c|}{ Pond } & Pond 1 \\
\hline $\begin{array}{l}\text { Spillway crest, in feet above pond bot- } \\
\text { tom }\end{array}$ & 4 & 5 & 6 & 4.36 & 4 & 5.2 & 2.2 \\
\hline $\begin{array}{l}\text { Water table depth, in feet below land } \\
\text { surface }\end{array}$ & -- & -- & -- & -- & -- & -- & 1.65 to 2.00 \\
\hline $\begin{array}{l}\text { Infiltration into dry pond bottom, in } \\
\text { inches }\end{array}$ & 2.5 & 0.25 & 0.25 & 0.25 & 0.25 & 1 & 2 \\
\hline Seepage rate, in inches per day & 0 to 0.10 & 0 to 0.25 & 0 to 0.25 & 0 to 0.25 & 0 to 1 & 0 to 1 & 0 to 1 \\
\hline
\end{tabular}
bottom can change throughout the year, the hydraulic conductivity of the pond bottom material does not change. Seepage rates were assumed to be zero inches per day during the winter because of the freezing of the soils and pond (table 7). Infiltration is simulated as inches below the pond bottom

Table 7. Parameters used for the pond model portion of the SPAW models for study areas B, D, and S, 2003-18.

$[--$, no data $]$ 
that need to be saturated before water will accumulate in the modeled wetland. This infiltration value varied by site and ranged between 0.25 and 2.5 inches depending on the soil type underlying the wetland (table 7).

Monthly potential ET was estimated from annual potential ET for use in the SPAW models. Within SPAW, a monthly percentage is applied to the annual potential ET to simulate monthly variability throughout the year. The monthly value for ET is converted to a daily value within the model by dividing the monthly value by the number of days in the respective month.

\section{Boundary and Initial Conditions}

To account for the evaporative and drainage properties of soil layers, two boundary layers are used in the field hydrology model in SPAW that include a 0.5- to 1-inch evaporative layer above the uppermost soil layer and an "image" layer below the deepest soil layer in the soil profile (fig. 6; appendix tables 1.1 through 1.3). The upper evaporative boundary layer has the same functions of the other soil layers in the profile except no roots are simulated in this layer (Saxton, 2002). The water is readily evaporated out of this upper boundary layer and is only limited by potential ET with the lower limit for water content in this layer set just below the wilting point. Water can move upward through the soil profile into the evaporative layer and is estimated using a modified Darcy equation with a reduced unsaturated conductivity rate for the current water content (Saxton, 2002). A reduction in the conductivity is used because evaporation is mostly vapor flow and not liquid flow, resulting in a lower effective conductivity.

The "image" layer in the field hydrology model is a separate layer below the deepest soil layer that is assigned the same characteristic as the deepest soil layer (appendix tables 1.1 through 1.3). The drainage out of the "image" layer can be defined three ways as follows: (1) freely draining so the water will drain from the "image" layer when the moisture content reaches a specified percentage of the field capacity because of percolation through the profile; (2) restricted drainage from the "image" layer so that water will drain at a specified maximum flow rate in inches per day when the water content reaches 90 percent saturation; and (3) a rising water table where water will flow upward in the soil profile at the specified maximum flow rate, if a water table is specified (table 6; Saxton and Willey, 2004).

In the SPAW model, routines for simulating shallow groundwater can be included in the field and pond models, but were only used for the field and pond model for study area S. The water table routine was included because measured water level data collected April 2018 through October 2018 in the wetland and shallow groundwater indicated that the water levels in the pond were connected to the shallow groundwater table in the area. A constant water table depth of 27.8 inches below land surface throughout the modeling period was used as a base value for the soil profile in the field hydrology model (table 6). Two water table depths were used in the pond model at study area S; a water table depth of $2.00 \mathrm{ft}$ below land surface was used for May 1 through June 7, and a water table depth of $1.65 \mathrm{ft}$ below land surface was used for June 8 through October 18 (table 7). The water table depth used for May 1 through June 7 was determined based on the measured water levels in May 2018. The $1.65 \mathrm{ft}$ value used for June through October was selected because after each precipitation event in 2018, the measured water levels continued to return to about $1.65 \mathrm{ft}$ below land surface. Therefore, the base water level for the wetland was estimated to be $1.65 \mathrm{ft}$.

Several initial conditions were set for the field hydrology model and a pond model in SPAW for the three study areas. For the pond model in SPAW to simulate the wetlands in the three study areas, an initial water depth in the wetlands was needed to start the simulation. Because no water-level data were available for the beginning of the simulation (January 1, 2003), the value used as the initial water depth for each study area was based on the initial water-level measurement during the data collection period from April 2018 through October 2018. The initial water depths used for the model were 1.50 and $1.65 \mathrm{ft}$ for the models of study areas B and S, respectively (table 7). Multiple wetlands were simulated in study area $\mathrm{D}$, and the initial water depths ranged from 1.00 to $3.00 \mathrm{ft}$ (table 7). For the SPAW model at study area S, where the groundwater table function was used, an initial water table depth was set at 27.8 inches for the field hydrology model portion (table 6) and at $1.65 \mathrm{ft}$ below land surface for the pond model portion (table 7).

\section{DRAINMOD}

Approximate methods are used in DRAINMOD to quantify the hydrologic components of subsurface drainage, subirrigation (not used in models for this report), infiltration, ET, and surface runoff (fig. 9). For example, equations developed by Hooghoudt (1940), Luthin (1957), Ernst (1975), and Taylor and Luthin (1978) are used to calculate drainage and subirrigation rates, and infiltration rates are predicted by the Green-Ampt equation (Green and Ampt, 1911). Complex numerical methods were avoided by assuming a drained to equilibrium state for the soil water distribution above the water table. The term water table is usually used to describe the water level in an unconfined aquifer; however, in this report, water table describes the level of saturation in the soil profile within DRAINMOD. Inputs to the model were soil properties, weather data, crop variables, and subsurface drainage configurations. Other applications of DRAINMOD mostly have been calibrated and validated on field plot scales of 0.5 to 5 acres (for example, Skaggs and others, 1982; Salazar and others, 2009; Thorp and others, 2009). Models developed for study areas B, D, and S, had fields ranging from 54.4 acres (study area S) to 664.7 acres (study area D; table 1 ). Similar to SPAW, DRAINMOD water table estimates are one-dimensional (vertical). The reliability of DRAINMOD has been tested for a wide range of soil, crop, and climatological conditions in other applications. Models developed in North 
Carolina (Skaggs and others, 1982), Ohio (Skaggs and others, 1981), Louisiana (Gayle and others, 1985; Fouss and others, 1987), Florida (Rogers, 1985), Virginia (McMahon and others, 1988) and Belgium (Hendrosusanto and others, 1987) indicated that the model can be used to reliably predict water table elevations and drain flow rates.

\section{Model Parameters}

Hydrologic simulations of fields affected by subsurface drainage were done using DRAINMOD version 6.1 (North Carolina State University, 2020) for each of the three study areas. Input data required for calibration and implementation of the DRAINMOD applications included time-series data such as precipitation and air temperature and several fixed parameters to describe the subsurface drainage system and the runoff and infiltration processes on the surface and subsurface (fig. 9; Skaggs and others, 2012).

Soil property inputs included the saturated lateral hydraulic conductivity (by layer), the relation between drainage volume and water table depth, and the upward flux from the water table (table 8; appendix tables 2.1 through 2.7). Most of these parameters were estimated using the ROSETTA program (Schaap and others, 2001) based on soil properties obtained from the National Cooperative Soil Survey database (National Cooperative Soil Survey, 2019) for each study area. The Green-Ampt equation (Green and Ampt, 1911) is used in the model to compute infiltration, and the coefficients used in the equation also were estimated by the ROSETTA program for input to DRAINMOD (appendix table 2.5). DRAINMOD uses approximate relations developed from soil-water characteristics and unsaturated hydraulic conductivity relations to simulate storage and redistribution of water in the soil profile. Soil-water characteristics for each soil layer also were estimated using the ROSETTA program for input to DRAINMOD (appendix tables 2.1 through 2.3).

Subsurface drainage was defined in the models using input parameters for the drain depth, spacing between the drains, drain-pipe size, and outlet functions (table 8). Information on subsurface drainage design for use in DRAINMOD was obtained from NRCS (table 1; Jonathan Peterson, Natural Resources Conservation Service, written commun., 2019). DRAINMOD simulates the effects of various water management simulations on the water table by performing a one-dimensional water balance at the midpoint between adjacent drains, by means of equation 3 as follows:

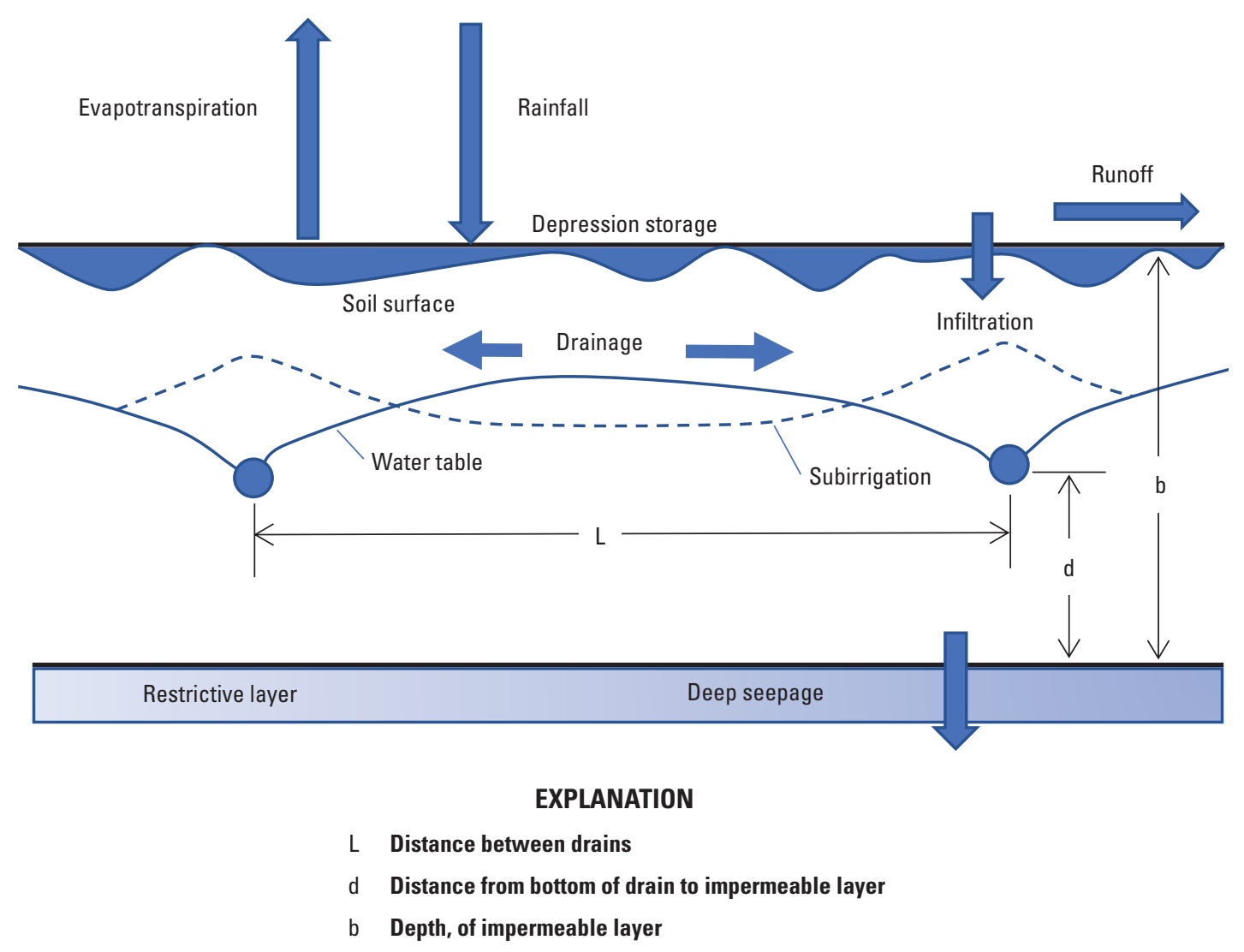

Figure 9. Conceptual diagram of processes simulated in the DRAINMOD model. Modified from Skaggs and others (2012). 
where
$\partial V_{a} \quad$ is the drained volume, in inches;
$D$ is the lateral drainage, in inches, from the section;
ET is evapotranspiration, in inches;
DS is the deep (vertical) seepage, in inches; and
$F \quad$ is infiltration, in inches, entering the section in time increment $\partial t$.

Fields with complex drainage systems (for example, different drainage diameters, spacing, or depths) can be subdivided into homogenous units for analysis (Skaggs and others, 2012). Although various drainage pipe diameters and spacing were in the subsurface drainage systems in the three study areas, a uniform system was chosen for the simulations using a single drainage diameter, spacing, and depth value at each study area (table 8).

Other parameters were included in the model to describe seepage and crop-related processes controlling runoff and infiltration. The seepage routine in the model was only used in the application of DRAINMOD for study area S (table 8). Croprelated parameters were the same for models at all three study areas and were constant for the simulation period and included the lower limit of water content, limiting water table depth, definition of wet and dry periods in the year, and monthly root depths (table 8). Values for the crop-related parameters were based on values used in other DRAINMOD applications in eastern North Dakota and Minnesota by NRCS (appendix table 2.8; Jonathan Peterson, Natural Resources Conservation Service, written commun., 2019) and were adjusted for model calibration.

DRAINMOD numerically solves the heat flow equation and predicts soil temperature to simulate processes controlling field hydrology under conditions such as freezing, thawing, and snowmelt (Luo and others, 2000). The model has been tested under cold climates in the United States (Jin and Sands, 2003), Canada (Wang and others, 2005), and Turkey (Luo and others, 2001), and predicted values generally agreed well with field data. Default values in DRAINMOD from previous applications were used for the models developed for the three study areas (table 8).

Changes in ET as a result of drainage are a primary determinant of the hydrologic alterations from subsurface drainage (Skaggs and others, 2012). ET is generally the second largest component of the hydrologic cycle and, along with precipitation, determines how much water is available to leave the field by surface runoff, drain outflow, or deep seepage. The modified Thornthwaite method was used in the DRAINMOD model to estimate potential ET based on daily minimum and maximum air temperature. Monthly correction factors were used to correct estimates because the Thornthwaite method can, at times, underestimate or overestimate potential ET at different times of the year compared to the Penman-Montieth method (Skaggs and others, 2012). Initial monthly correction factors were based on values used in other DRAINMOD applications in eastern North Dakota and Minnesota by NRCS (appendix table 2.8; Jonathan Peterson, Natural Resources Conservation Service, written commun., 2019) and were adjusted for model calibration.

\section{Boundary and Initial Conditions}

Several boundary conditions were set to define the modeling domain used in each of the DRAINMOD models for the three study areas. One of the main boundary conditions is the definition of an impermeable layer; including the depth and characteristics that determine deep seepage to groundwater such as thickness of layer, vertical conductivity of the layer, and the hydraulic head of the underlying aquifer (table 8). The seepage component of the impermeable layer is optional in the model, and only the depth of the impermeable layer is required. The seepage function was only used in the DRAINMOD application for study area S. The depths of the impermeable layers for study areas B, D, and S were set to 78.7, 39.4, and 39.4 inches, respectively (table 8). Crop-related boundary conditions included defining a lower limit of water content in the root zone, the limiting water table depth, and definitions of wet periods and dry periods, which are all defined the same for models in all three study areas (table 8).

Several conditions were set for initiating the simulations using DRAINMOD for the three study areas that included initial water table depth, initial soil temperature, and initial snow depth. The soil temperatures and snow depth were set to the same values for DRAINMOD models at all three study areas (table 8). No information was available for initial water table depths for the beginning of the simulation period (January 1 , 2003); therefore, the values were initially set to an arbitrary number of 20 inches and were adjusted during the calibration process.

\section{Model Evaluation Methods}

To evaluate the performance of the models, simulated and measured water depths in the wetlands for the SPAW models and simulated and measured water table depths of the shallow groundwater in the DRAINMOD models were compared for the three study areas. Output from both models is in the form of water depth, so water levels from the wetlands were converted to water depth using surveyed elevation data and the depth-capacity curves for each wetland. Groundwater levels were converted to water table depth using surveyed land-surface elevation data. Land-surface elevation data used to convert water levels to water table depths at specific sites (table 2) are available from the USGS NWIS database (U.S. Geological Survey, 2020a). Simulated and measured 
Table 8. Parameters used for DRAINMOD models for study areas B, D, and S, 2003-18.

$[--$, no data $]$

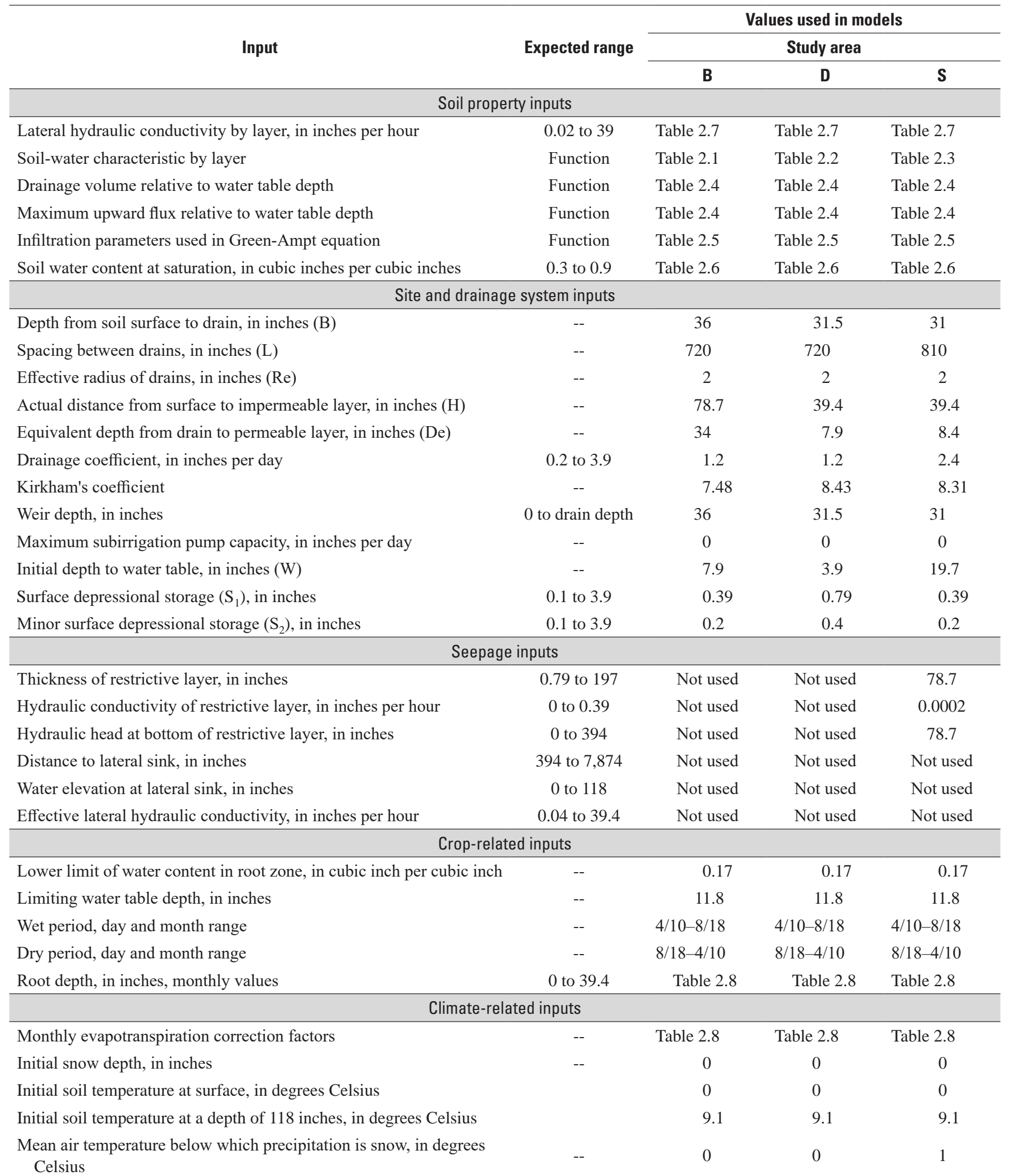


Table 8. Parameters used for DRAINMOD models for study areas B, D, and S, 2003-18. - Continued

$[--$, no data $]$

\begin{tabular}{|c|c|c|c|c|}
\hline \multirow{3}{*}{ Input } & \multirow{3}{*}{ Expected range } & \multicolumn{3}{|c|}{ Values used in models } \\
\hline & & \multicolumn{3}{|c|}{ Study area } \\
\hline & & B & D & $\mathbf{S}$ \\
\hline $\begin{array}{l}\text { Mean air temperature above which snow starts to melt, in degrees } \\
\text { Celsius }\end{array}$ & -- & 1 & 1 & 2 \\
\hline
\end{tabular}

daily water depths were compared for April 26, 2018, through October 28, 2018, using the absolute mean error (AME) and the root mean square error (RMSE) to evaluate model performance. The AME calculates the mean difference between simulated and measured values and is calculated using equation 4.

$A M E=\frac{\sum \mid \text { simulated value }- \text { measured value } \mid}{\text { number of observations }}$

An AME of $0.1 \mathrm{ft}$ indicates that the mean difference between the simulated and measured values for the model run was $0.1 \mathrm{ft}$

The RMSE indicates the spread of how far simulated values deviate from the measured values and is calculated using equation 5 .

$R M S E=\sqrt{\frac{\sum(\text { simulated } \text { value }- \text { measured value })^{2}}{\text { number of observations }}}$

An RMSE of $0.1 \mathrm{ft}$ indicates that the simulated water values are within $0.1 \mathrm{ft}$ of the observed values about 67 percent of the time.

A sensitivity analysis was done for the SPAW and DRAINMOD models to evaluate which parameters affected model simulations the most. Not all parameters were included in the analysis, but a subset of parameters was identified in the calibration process for use in the sensitivity analyses. Sensitivity analysis was done on SPAW using the models developed for study areas B and S and on the DRAINMOD model developed for study area D. The mean difference between the calibrated and sensitivity test values of daily water depths in the wetlands for the SPAW models and the water table depths in shallow groundwater in the DRAINMOD models were computed for the simulation period (January 1, 2003, through December 31, 2018) for comparison.

\section{Evaluation of Model Simulations Using SPAW}

SPAW models were developed and calibrated at the three study areas (study areas B, D, and S) to evaluate how the models simulated field-scale hydrologic characteristics and the water balance in wetlands from January 1, 2003, through December 31, 2018. Measured water-depth data were used for comparison to simulated water depths in the wetlands from April 2018 through October 2018. A sensitivity analysis also was done to evaluate how simulated processes were affected by various parameters. The sensitivity analysis provides information on what inputs may be the most important for collecting data because of the relative effect each input has on the simulated hydrology.

\section{Model Calibration}

SPAW models simulated field-scale hydrology processes and water balance in adjacent wetlands from January 1, 2003, through December 31, 2018, in the three study areas in southeast North Dakota (study areas B, D, and S). Many of the processes simulated in the models are difficult to measure, such as runoff from the fields and infiltration in the unsaturated zone; however, water depths in the wetlands were measured from April 2018 through October 2018. The measured water depths were compared to simulated water depths to evaluate how well the SPAW models performed in each of the study areas. This section describes the simulated hydrologic characteristics and calibration of the SPAW models for the three study areas.

\section{Study Area B}

The SPAW model developed for study area B included five modeled fields in the field hydrology portion of SPAW that contributed inflow to one wetland simulated in the pond model portion of SPAW. Generally, simulated runoff and infiltration were greatest in years with the most precipitation in 
2010, 2013, and 2016 during the simulation period (January 1, 2003, through December 31, 2018; figs. 10A, B and 11A). Runoff generally occurred in response to multiple precipitation events in close succession or during prolonged events of several days when the simulated soil profile became saturated. The water depth in the simulated wetland responded accordingly, with the greatest depths in 2007, 2013, and 2016 (fig. 10C). Water depths stayed relatively high for prolonged periods in 2010 through 2011, 2013 through 2014, and 2016 through 2017 (fig. 10C) because of multiple years of increased precipitation (fig. 11A). The wetlands went nearly dry with simulated water depths near zero $\mathrm{ft}$ during the fall (September through November) and winter (December, January, and February) in 2006 through 2007, 2012 through 2013, and 2015 through 2016 (fig. 10C).

Simulated water depths from the pond model were compared to measured water levels recorded at two locations (sites BWET1 and BWET2) and converted to water depths (figs. 3 and 12) using the depth-capacity curve described in the "Depth-Capacity Curves and Elevation Data" section of this report. Simulated water depths were most similar to water depths measured at site BWET1, with an AME of $0.10 \mathrm{ft}$ and an RMSE of $0.14 \mathrm{ft}$. Site BWET2 had slightly larger errors, with an AME of $0.22 \mathrm{ft}$ and an RMSE of $0.28 \mathrm{ft}$ (fig. 12). Simulated water depths were similar to the pattern of measured water depths at BWET1 and BWET2 from about midApril 2018 through about mid-September 2018, but overpredicted water depths in the fall from about mid-September 2018 through about mid-October 2018 (fig. 12). Because water depths were generalized into a single depth-capacity table for the multiple wetlands in study area B, the model was calibrated to follow the general pattern of water-level fluctuations at the measurement sites. The larger wetland in study area B (wetland 1; fig. 3) is at times connected to the smaller wetlands, but during dry years or dry periods during any given year, this site has four distinct wetland areas. During wet conditions, measured water levels tend to be similar among the wetlands, whereas during dry conditions, water levels tend to be different among the wetlands.

\section{Study Area D}

The SPAW model developed for study area D included six modeled fields in the field hydrology portion of SPAW that contributed inflow to five wetlands connected in series in the pond model portion of SPAW (figs. 4 and 8). Patterns in simulated runoff and infiltration were similar to the simulated results from study area B; however, precipitation was distributed slightly different, resulting in the greatest simulated runoff in 2007, 2011, and 2013 and the greatest infiltration in 2005, 2013, and 2016 during the simulation period (January 1, 2003, through December 31, 2018; figs. 11B and 13B). The least runoff and infiltration were in 2006, 2012 and 2017 (fig. 11B). The water depth in the simulated wetland responded accordingly, with the greatest depths in 2007, 2011, and 2016 (fig. 13C). In general, water depths in the wetlands maintained fairly stable levels for most of the year during the simulation period because of relatively steep bank slopes and control by the culverts that connect the wetlands. However, the water depths reacted to precipitation events for short periods throughout the simulation period (fig. 13C). Wetland 5 (figs. 4 and 13C) was nearly dry in the fall (September through November) of 2003, 2011, 2012, 2015, and 2016.

Simulated water depths were compared to water depths measured in the five wetlands included in the model (fig. 14). Simulated water depths compared relatively well to water depths in the five wetlands, with the AME ranging from $0.17 \mathrm{ft}$ (DWET1) to $0.39 \mathrm{ft}$ (DWET2), and the RMSE ranging from $0.28 \mathrm{ft}$ (DWET1) to $0.56 \mathrm{ft}$ (DWET5; fig. 14). Differences between the simulated and measured water depths among the five wetlands may be partially due to the estimations of flow between the wetlands through the connecting culverts. Pond models for the five wetlands were simulated in series, with the upstream wetland being used as an input into the next downstream wetland. Each pond has an outlet that either is described as a culvert or as a channel. No discharge measurements were collected during the data collection period and discharges out of each pond were estimated using Manning's equation or the culvert equations described in Carter (1957).

Another reason for differences between simulated and measured water depths may be from the distribution of inflow from subsurface drainage from the DRAINMOD simulation. DRAINMOD only provides a single value of daily outflow; however, the actual subsurface drainage system has multiple outlets (fig. 4), and the single daily values were proportioned among the three outlets into the appropriate wetland in the SPAW model. Measured data were not available to determine the appropriate distribution; therefore, the apportionment was somewhat arbitrary and may not completely reflect field conditions. Also, although daily drainage discharges are provided in the output from DRAINMOD, daily drainage discharges could only be input to SPAW as a constant value for a specified range of dates that was applied to every simulation year. Therefore, the model cannot fully simulate the variability in outflow from subsurface drainage throughout the range of hydrologic conditions.

\section{Study Area S}

The SPAW model developed for study area S included one modeled field in the field hydrology portion of SPAW that contributed inflow to one wetland in the pond model portion of SPAW (fig. 5). Patterns in simulated runoff and infiltration were similar to the simulated results from the other two study areas; however, precipitation was distributed slightly different, with the greatest annual totals in 2005, 2007, 2011, and 2016 (fig. 11C). The greatest simulated runoff was in 2004, 2007 , and 2016, but the greatest infiltration was in 2005, 2010, and 2011 during the simulation period (January 1, 2003, through December 31, 2018; figs. $11 C$ and $15 B$ ). The least runoff was in 2006, 2009, and 2014 and the least infiltration was in 2006, 2012, and 2015. Because of the small size of the wetland 

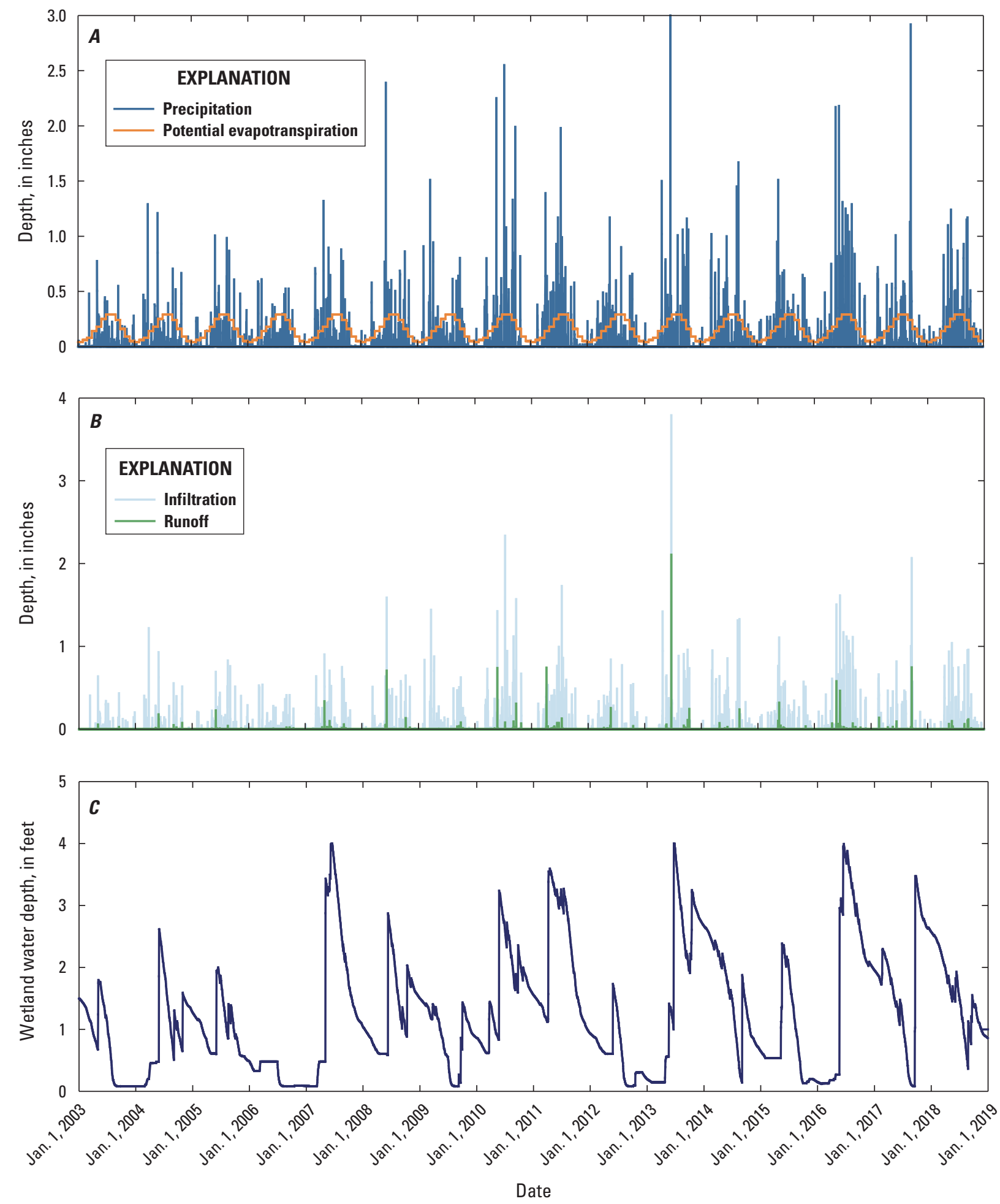

Figure 10. SPAW model results for study area $B$ from January 1, 2003, through December 31, 2018. A, Simulated precipitation and potential evapotranspiration; $B$, simulated infiltration and runoff; and $C$, simulated wetland water depth. 


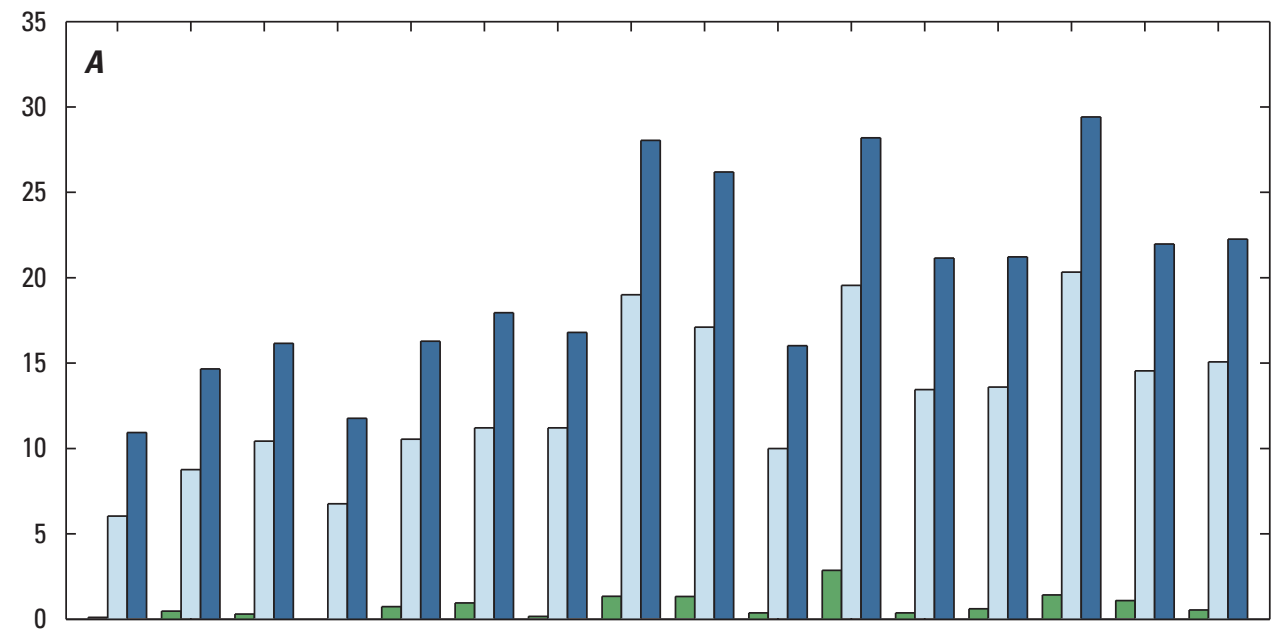

EXPLANATION

Simulated runoff

Simulated infiltration

Precipitation
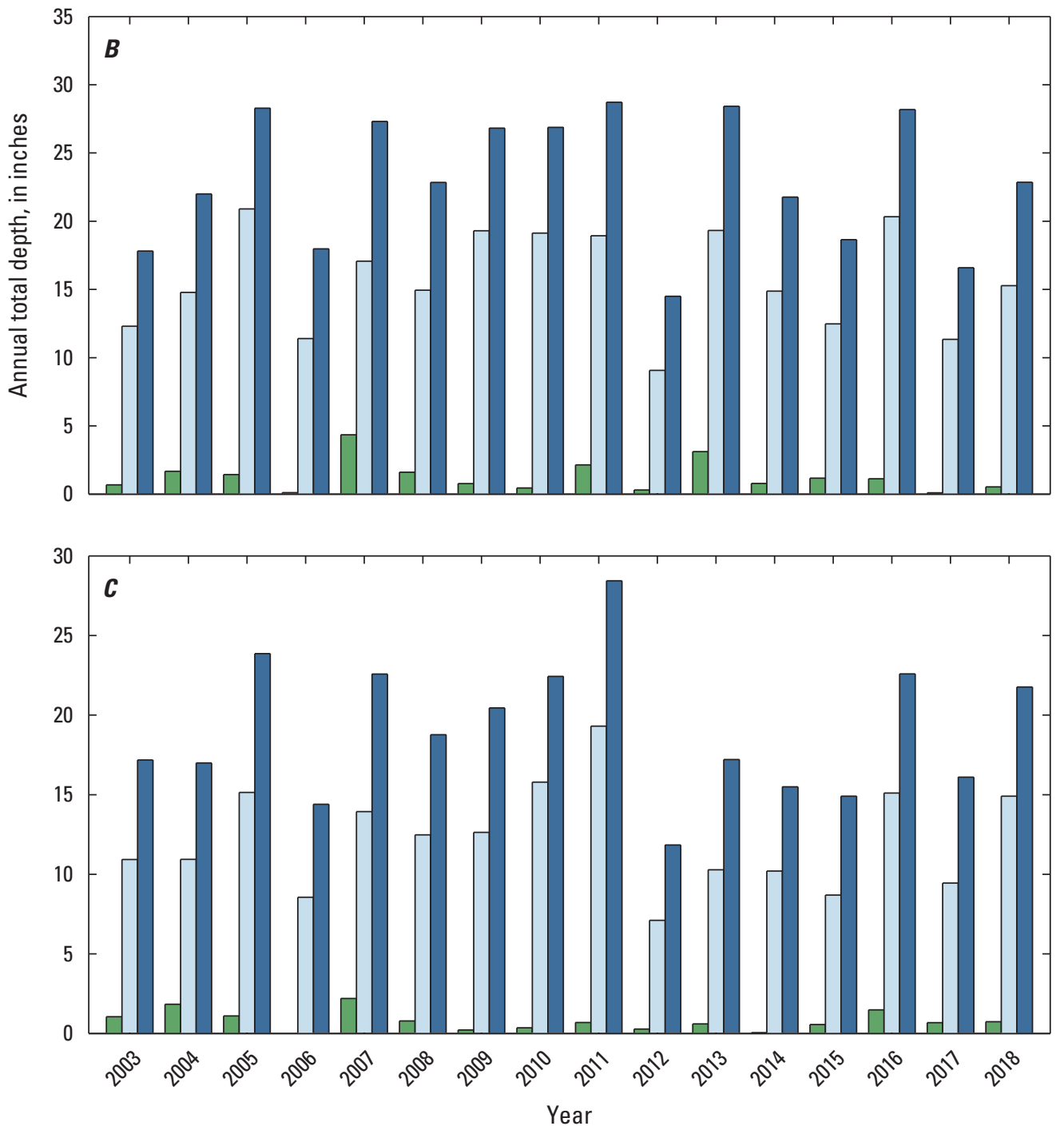

Figure 11. Total annual simulated precipitation, infiltration, and runoff from the SPAW models, 2003 through 2018. A, Study area $\mathrm{B} ; B$, study area $\mathrm{D}$; and $C$, study area $\mathrm{S}$. 


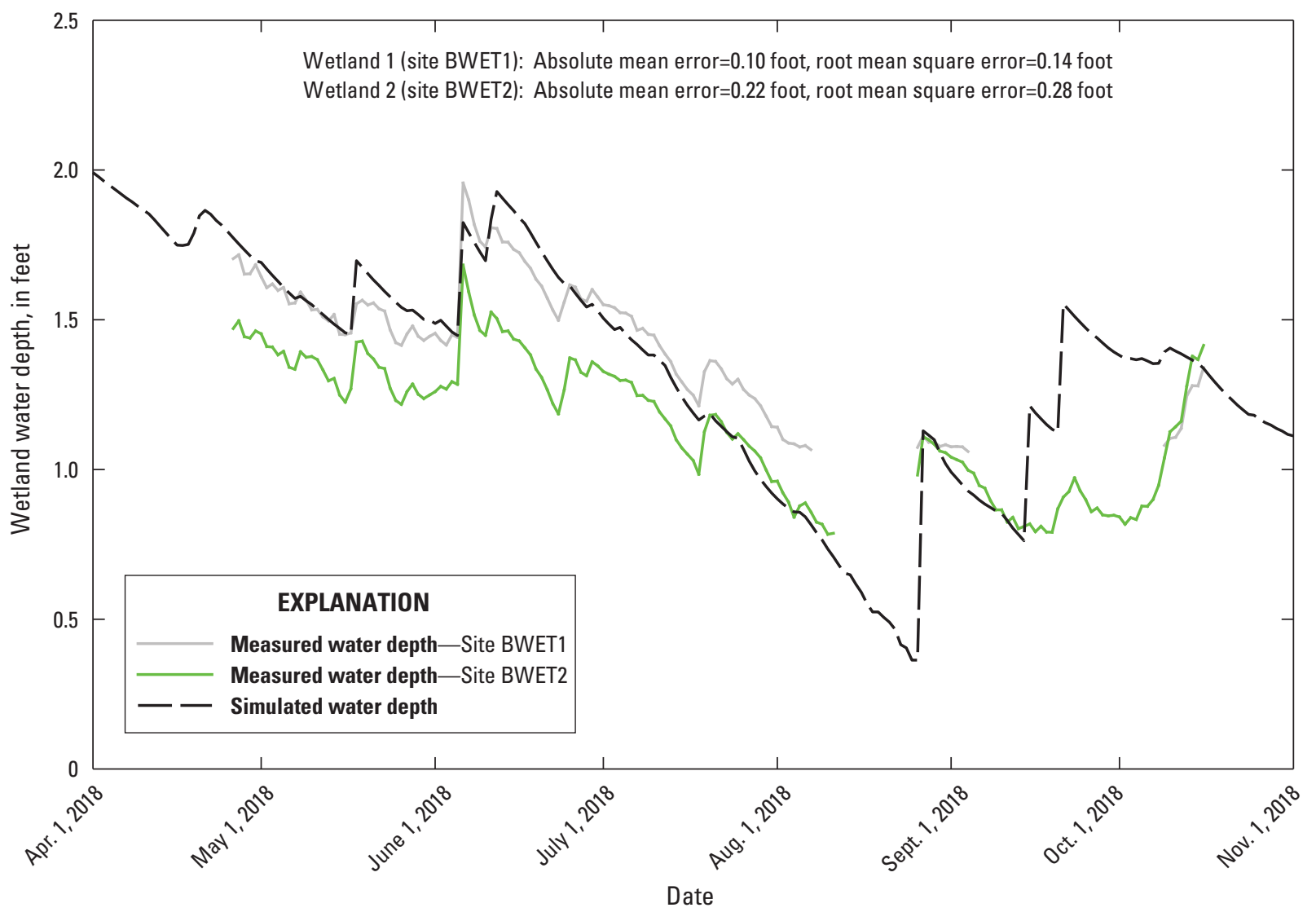

Figure 12. Simulated and measured water depths for wetlands 1 and 2 in study area B, April 2018 through October 2018.

simulated in study area $\mathrm{S}$, the variability in water depth in the wetland during the simulation period was limited by the size of the wetland and outflow from the wetland (fig. 15C). Water depths in the wetland did not exceed $2.2 \mathrm{ft}$ because $2.2 \mathrm{ft}$ was the height of the weir used in the model to simulate overflow from the wetland (table 7). For most of the time each year, water depths were near $1.65 \mathrm{ft}$ because the initial water table depth was set at $1.65 \mathrm{ft}$ in the model. Water depths would decrease below $1.65 \mathrm{ft}$ generally when little water was added to the system; consequently, the simulated water table would decrease below the initial water table depth.

Simulated water depths were compared to measured water depths measured in the single wetland included in the model (fig. 16). Among the SPAW models developed for the three study areas, the model for study area $\mathrm{S}$ showed the best comparison between simulated and measured water depths. The study area $\mathrm{S}$ model had an AME of $0.06 \mathrm{ft}$ and an RMSE of $0.10 \mathrm{ft}$ (fig. 16). Study area $\mathrm{S}$ was the smallest modeling area among the three study areas and included only one modeled field. The simple model design may have contributed to the better fit between simulated and measured depths in the wetland compared to the other study areas.

\section{Sensitivity Analysis}

Sensitivity analysis was done to evaluate parameters in the SPAW model to determine which parameters have the most effect on simulated results. The sensitivity analysis also was used to evaluate model performance in describing hydrologic processes and to provide information on what parameters may be important for careful consideration during model development. When modeling natural systems, simulations are always approximations of the actual conditions that exist in the system. Although many parameters within SPAW are used to describe hydrologic processes in one or more fields and in an impoundment or water body such as a wetland, a subset of parameters was selected for a sensitivity analysis based on those parameters adjusted most frequently during calibration. The models developed and calibrated for study areas B and S were selected for the sensitivity analysis to compare the sensitivity of selected parameters in a relatively simple modeled area (study area $\mathrm{S}$ ) and a more complex modeled area (study area B). Parameters used in the field hydrology model and pond model within SPAW were tested. 

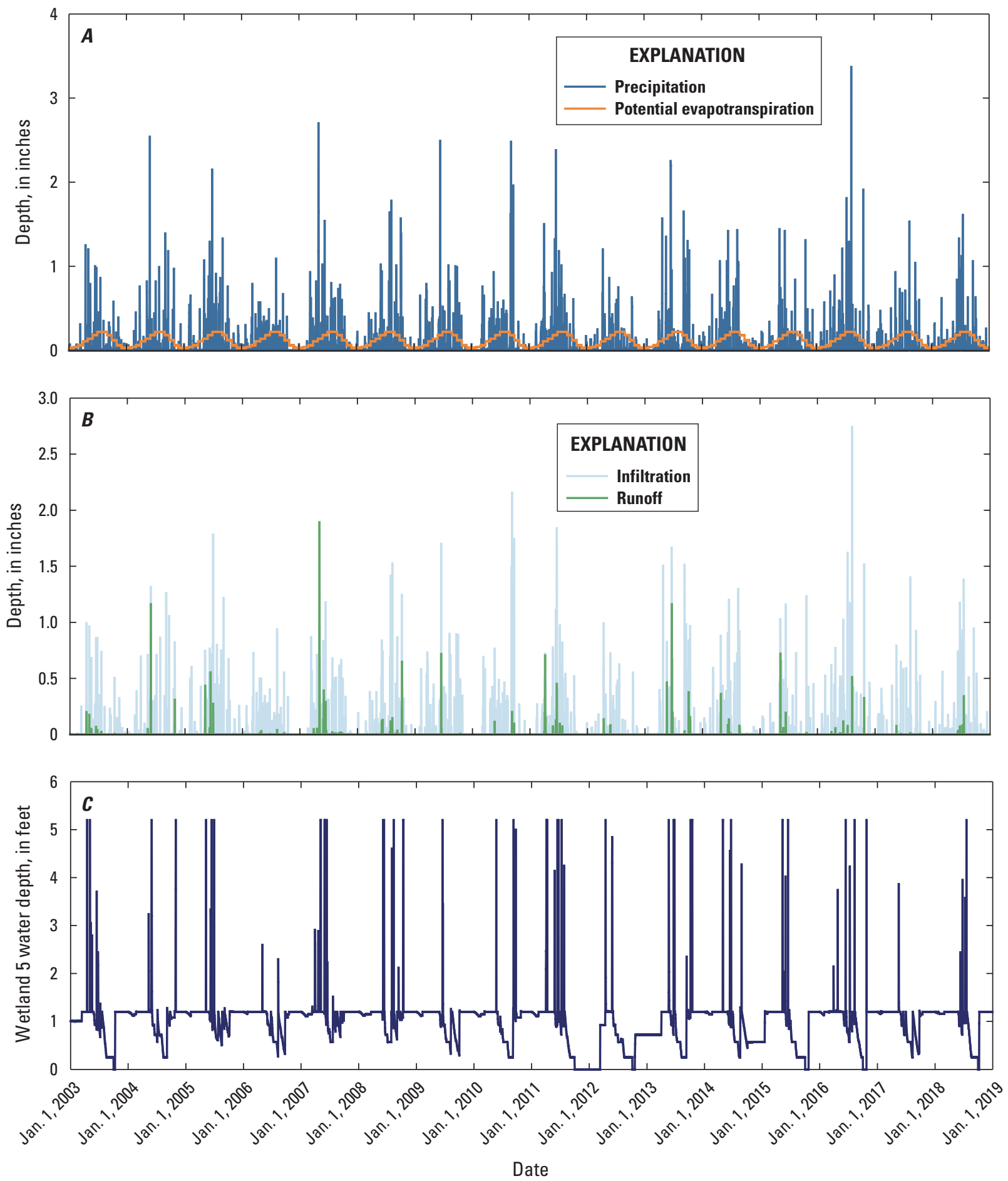

Figure 13. SPAW model results for study area $D$ from January 1, 2003, through December 31, 2018. A, Simulated precipitation and potential evapotranspiration; $B$, simulated infiltration and runoff; and $C$, simulated wetland water depth in wetland 5 . 

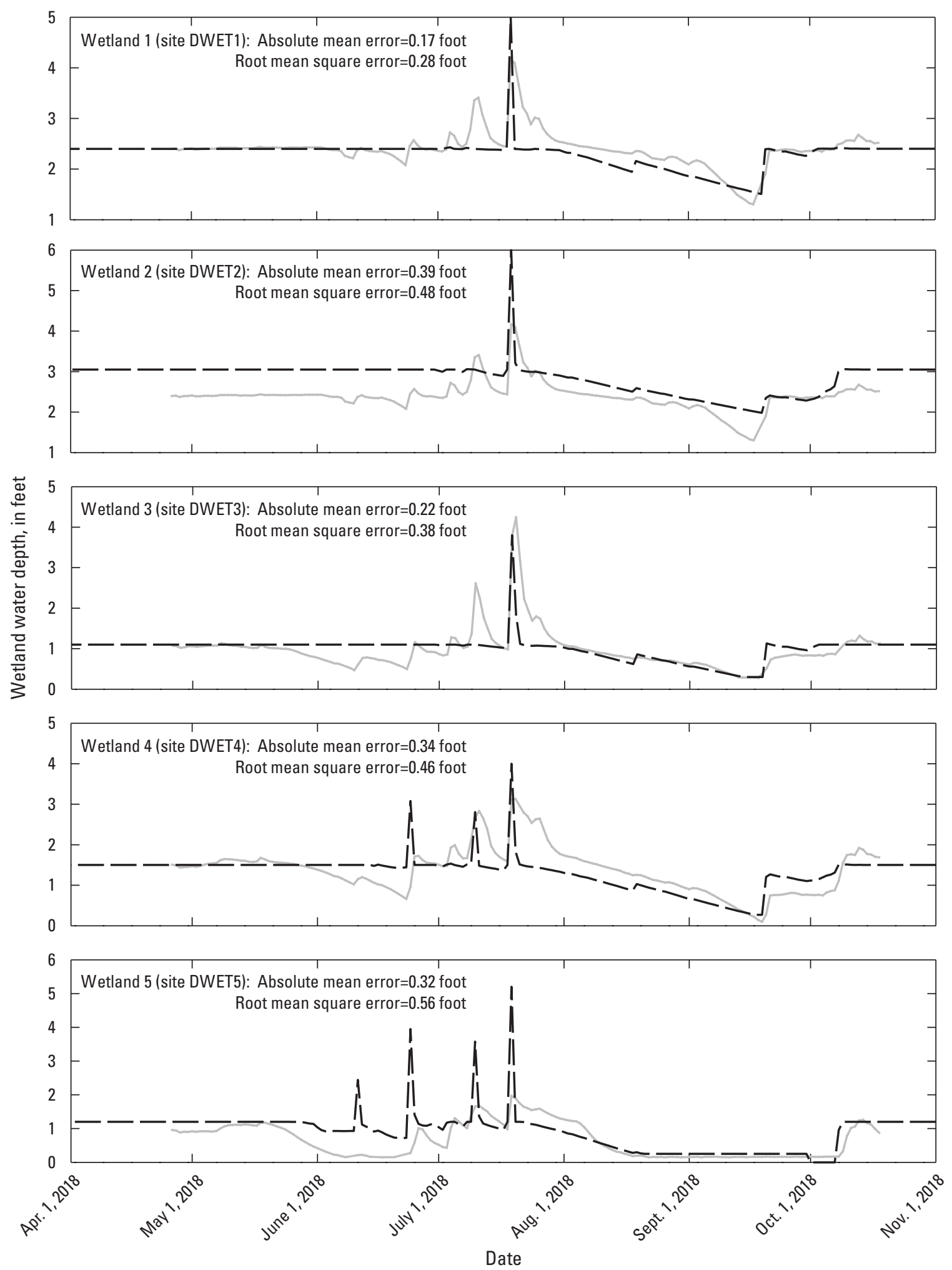

EXPLANATION

\section{Measured water depth $\quad-$ Simulated water depth}

Figure 14. Simulated and measured water depths for the wetlands in study area D, April 2018 through October 2018. 

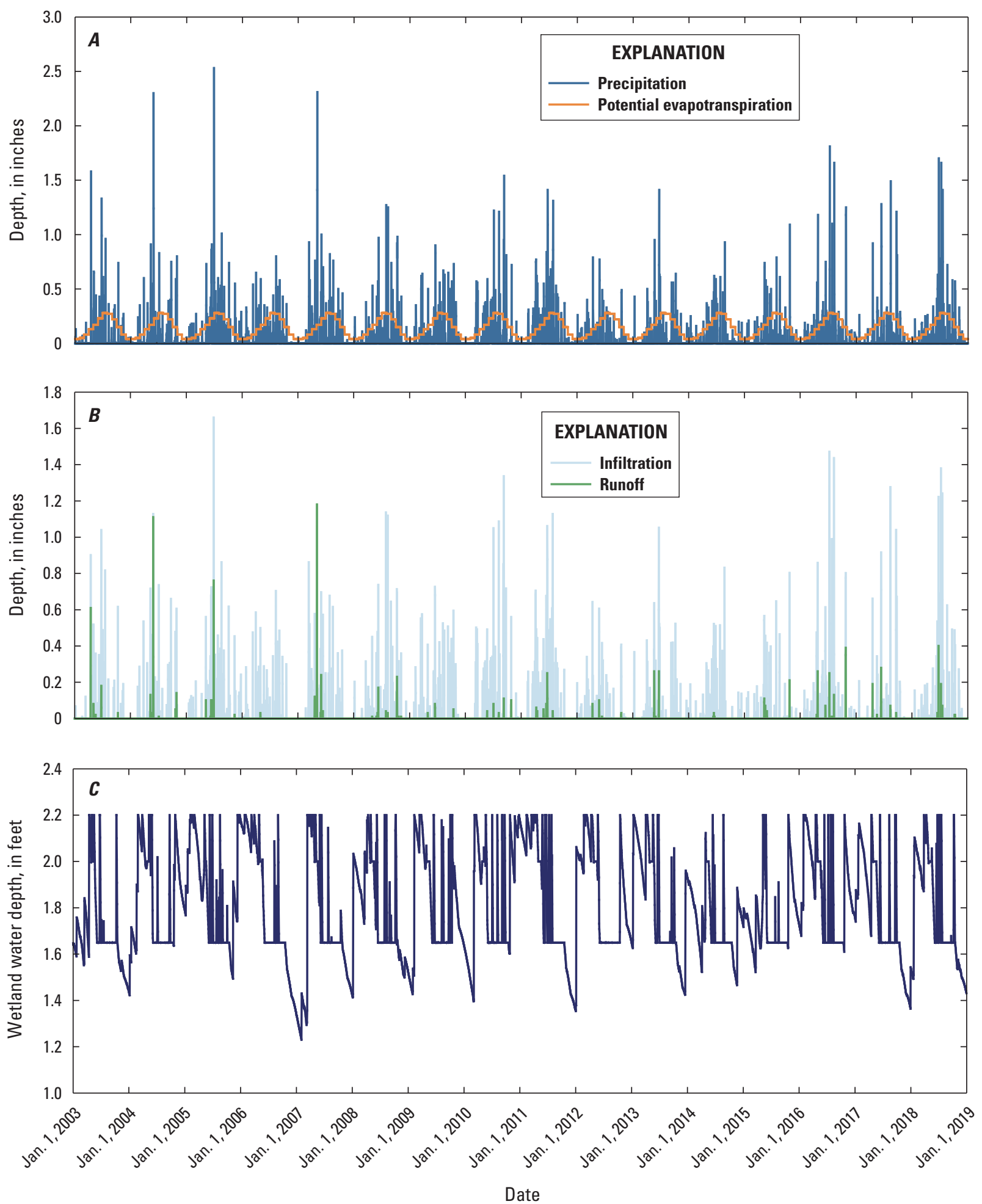

Figure 15. SPAW model results for study area S from January 1, 2003, through December 31, 2018. A, Simulated precipitation and potential evapotranspiration; $B$, simulated infiltration and runoff; and $C$, simulated wetland water depth. 


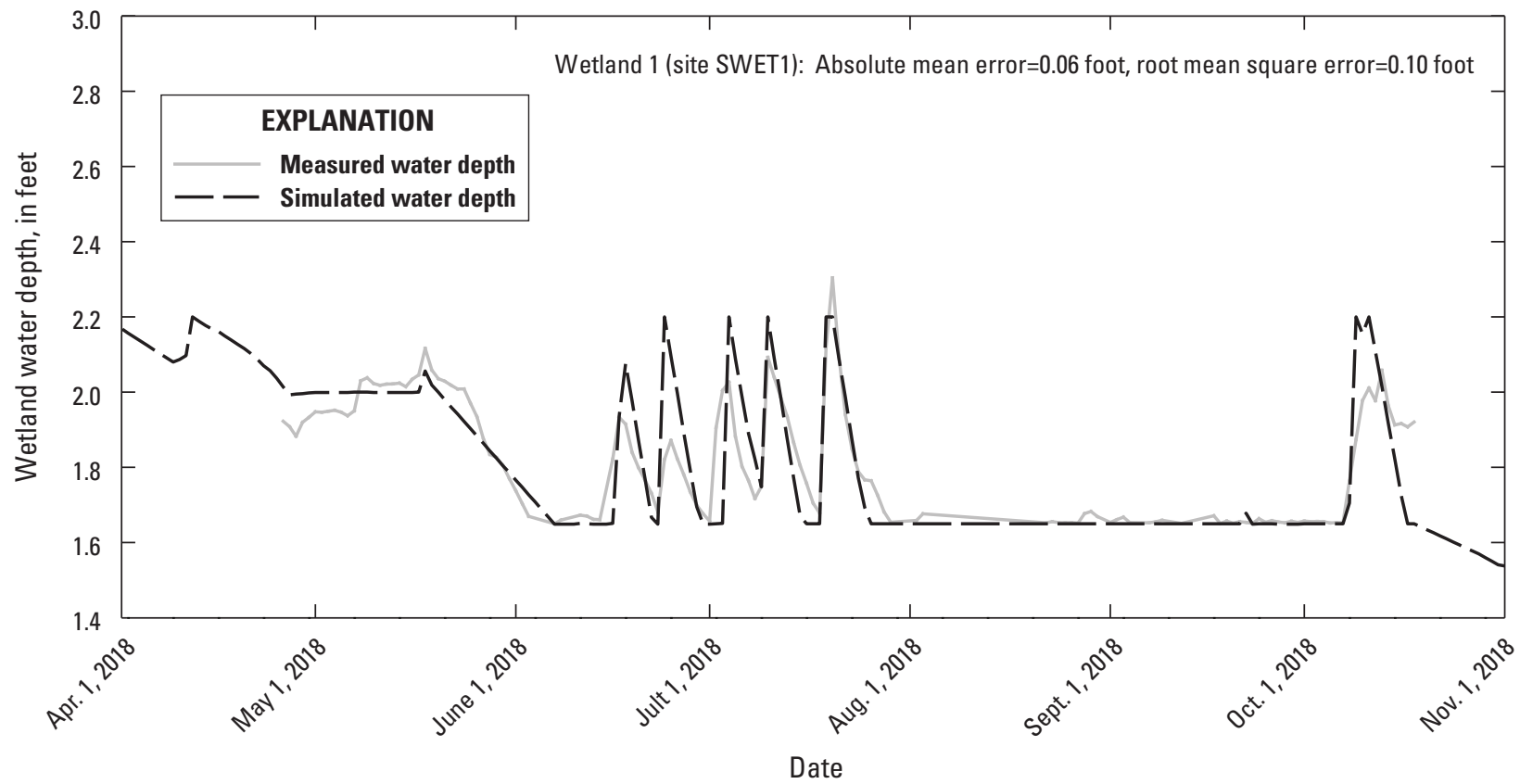

Figure 16. Simulated and measured water depths for the wetland in study area S, April 2018 through October 2018.

Table 9. Results of sensitivity analysis for the SPAW model for study areas B and S, 2003-18.

$[--$, no data $]$

\begin{tabular}{|c|c|c|c|}
\hline \multirow[b]{3}{*}{ Parameter } & \multirow{3}{*}{$\begin{array}{l}\text { Input, in } \\
\text { percent } \\
\text { change } \\
\text { from } \\
\text { calibrated } \\
\text { value }\end{array}$} & \multicolumn{2}{|c|}{ Study area } \\
\hline & & B & $\mathbf{s}$ \\
\hline & & $\begin{array}{c}\text { Mean difference in } \\
\text { wetland water depth } \\
\text { (sensitivity test minus } \\
\text { calibrated value), } \\
\text { in feet }\end{array}$ & $\begin{array}{l}\text { Mean difference in } \\
\text { wetland water depth } \\
\text { (sensitivity test minus } \\
\text { calibrated value), } \\
\text { in feet }\end{array}$ \\
\hline \multirow{2}{*}{ Potential evapotranspiration (field and pond model) } & +20 & -0.21 & -0.05 \\
\hline & -20 & 0.28 & 0.04 \\
\hline \multirow{2}{*}{ Seepage rate (pond model) } & +20 & -0.04 & 0.0009 \\
\hline & -20 & 0.04 & 0.0018 \\
\hline \multirow{2}{*}{ Pond bottom infiltration (pond model) } & +20 & -0.1 & -0.001 \\
\hline & -20 & 0.08 & 0.0001 \\
\hline \multirow{2}{*}{ Soil water evaporation conductivity (field model) } & +50 & 0.006 & -0.002 \\
\hline & -50 & -0.02 & 0 \\
\hline \multirow{2}{*}{ Water table depth (field model) } & +50 & -- & 0.35 \\
\hline & -50 & -- & -0.29 \\
\hline $\begin{array}{l}\text { Study area B-Hydrologic soil group D (clay) (calibrated } \\
\text { field model used hydrologic soil groups B and C) }\end{array}$ & -- & 0.45 & -- \\
\hline $\begin{array}{l}\text { Study area B-Hydrologic soil group A (loamy sand) (cali- } \\
\text { brated field model used hydrologic soil groups B and C) }\end{array}$ & -- & -0.1 & -- \\
\hline $\begin{array}{l}\text { Study area S-Hydrologic soil group D (clay) (calibrated field } \\
\text { model used hydrologic soil group A, loamy sand) }\end{array}$ & -- & -- & -0.15 \\
\hline $\begin{array}{l}\text { Study area S-Hydrologic soil group B (silty loam) (calibrat- } \\
\text { ed field model used hydrologic soil group A, loamy sand) }\end{array}$ & -- & -- & 0.26 \\
\hline
\end{tabular}


Simulated water depth in the wetland at study area B was most sensitive to changes in potential ET and soil type (table 9). In general, the main drivers for a hydrologic budget are precipitation into the system and potential ET out of the system. Increasing the potential ET in the field and pond model by 20 percent resulted in a mean difference of $-0.21 \mathrm{ft}$ in water depth from the calibrated model. Decreasing potential ET by 20 percent resulted in a mean difference of $0.28 \mathrm{ft}$ from the calibrated water depth. The changes in simulated wetland water depths were less in study area S with changes in ET. The mean difference in wetland water depths were -0.05 and $0.04 \mathrm{ft}$ (table 9).

Many of the changes in parameters tested for sensitivity had less of an effect on simulated water depth in the model for study area S compared to study area B. This result likely is because of the implementation of the water table routine in the study area $\mathrm{S}$ model that was not used for the model in study area B. The water table routine likely reduced the sensitivity of other parameters to changes and how the parameters affect the simulated water depths in the wetland. The water table depth was tested for sensitivity for study area $\mathrm{S}$ by increasing and decreasing values by 50 percent and had a greater effect on simulated water depths in the wetland than any other parameters tested. Changes in water depth were 0.35 and $-0.29 \mathrm{ft}$ (table 9).

Soil parameters are not explicitly input in the field model portion of SPAW, rather soil characteristics are entered into SPAW and parameters are generated internally. Therefore, instead of changing a single parameter, the hydrologic soil group was changed to evaluate sensitivity, which affects several internally generated parameters. Soils are sorted into hydrologic soil groups A-D, and each soil group is dependent upon the least permeable soil layer in its simplest form (U.S. Department of Agriculture, 1972). Hydrologic soil group A has the least runoff potential and generally consists of sands and gravels, whereas hydrologic soil group D has the greatest runoff potential and generally consists of silts and clays (U.S. Department of Agriculture, 1972). Changing from hydrologic soil groups $\mathrm{B}$ and $\mathrm{C}$ to hydrologic soil group $\mathrm{D}$ in the study area B model increased the simulated water depth by a mean of $0.45 \mathrm{ft}$ for the simulation period. Changing to hydrologic soil group A had less of an effect on simulated water depth in the study area B model, with a mean decrease of $-0.1 \mathrm{ft}$ (table 9). Changing from hydrologic soil group A to hydrologic soil group $\mathrm{D}$ in the study area $\mathrm{S}$ model decreased the simulated water depth by a mean of $-0.15 \mathrm{ft}$ for the simulation period, and changing to hydrologic soil group B in the study area $\mathrm{S}$ model increased the water depth by a mean of $0.26 \mathrm{ft}$ for the simulation period (table 9). Because of the importance of water movement in the soil profile, the soil characteristics consequently have a substantial effect on the hydrologic processes in the model.

Other parameters used in the field and pond model portions of the SPAW model were tested but had less effect on simulated water depths than did changes to potential ET and soil type for study areas B and S models. For the pond model, seepage rate and the pond bottom infiltration rate were adjusted with an increase and decrease of 20 percent, resulting in a $0.1 \mathrm{ft}$ or less difference in water depth from the calibrated model for the simulation period (table 9). Changing the soil-water evaporation conductivity in the field model by 50 percent only changed the water depth in the wetland $-0.02 \mathrm{ft}$ from the calibrated study area B model and had no change to the water depth in the wetland for study area S.

\section{Model Limitations}

The SPAW model, similar to most models, provides a simplified estimation of the complex natural processes that control the hydrology of fields and wetlands, and because of assumptions made in the development and implementation of the models, the SPAW model has inherent limitations. The SPAW field hydrology model simulates a vertical daily water budget for an agricultural field (Saxton and Willey, 2004). This model has no infiltration time distribution less than daily and has no flow routing; therefore, this model is most suitable for small drainage basins (Saxton and Willey, 2004). The lack of flow routing capabilities makes modeling subsurface drainage outflow or streams in the drainage basin impossible. This issue can cause discrepancies between actual runoff and drainage into a wetland area compared to simulated results. The SPAW field hydrology model also is limited in its ability to model the heterogeneity of soil and crop properties across a drainage basin because the properties are applied uniformly in each modeled field. Soil properties can substantially change the output of the model because different soil properties will lead to increased or decreased runoff into the wetland areas. For each modeled field, a water table can also be defined with the soil properties. However, when using a water table as a boundary condition, there is no variation from year to year. Crop properties also can change the output of the model, although the heterogeneity of crops throughout a drainage basin is better handled by delineating each field by crop type.

The SPAW pond model has limitations with model inputs and the soil properties of the pond bottom. One of the potential model inputs is to include a groundwater table surrounding the wetland area. Similar to the field model, when using a groundwater table in the pond model, the groundwater table input has no variation from year to year. Another limitation is the application of the pond bottom properties that can only be described using two parameters - the inflow into the dry pond bottom and the outflow using a pond seepage rate. The lack of definition in the soil-water properties of the pond bottom can limit the ability to accurately model the seepage into the pond bottom. Also, the input of direct inflows to the model has limitations. For example, although daily inputs of subsurface drainage flow generated by DRAINMOD simulations for the simulation period were available, the subsurface drainage flow only could be input as a constant value for a specified range of dates that was the same every simulation year. Therefore, 
the model cannot fully simulate the variability in outflow from subsurface drainage throughout the range of hydrologic conditions.

The application and evaluation of the simulated processes in the SPAW models specific to the three study areas investigated in this report also had some limitations. Because measured data only were available for one growing season in 2018, the performance of the models only could be evaluated for the range of hydrologic and field management conditions that occurred during that period. Although the precipitation during the 2018 calibration period was above the mean, the model performance could not be evaluated for wetter years such as observed in 1986, 2010, and 2019 or for drier years such as observed in 1976, 1992, or 2006 (fig. 2). Also, site conditions changed during the simulation period (January 1 , 2003, through December 31, 2018), but had to be simulated uniformly throughout the simulation period. For example, at study area $\mathrm{B}$, the smaller mitigated wetlands in the wetland complex (wetlands 1, 2, and 3; fig. 3) were not present in the earlier portion of the simulation period but had to be treated as if the wetlands were present for the entire period. Similarly, the subsurface drainage systems were installed later in the simulation period in all three study areas but had to be treated in the models as if the drainage systems were present for the entire simulation period. The evaluation of how well the models simulated various hydrologic processes such as infiltration and field runoff also were limited because those processes are difficult to measure for comparison to simulated results. Measured data also could not be collected during the winter because of frozen soils and wetlands; therefore, model performance could not be evaluated during cold conditions. However, collection of additional soil temperature and soil moisture data could provide useful information for evaluating models in future applications.

\section{Evaluation of Model Simulations Using DRAINMOD}

DRAINMOD models were developed and calibrated at the three study areas (study areas B, D, and S) to evaluate how the models simulated field-scale hydrologic characteristics for fields affected by subsurface drainage from January 1 , 2003, through December 31, 2018. DRAINMOD models also provided inflow from subsurface drainage discharge to the SPAW models for simulating water depths in wetlands in the study areas. Measured water table data were collected in shallow groundwater wells in each study area for comparison to simulated water table depths from April 2018 through October 2018. The term water table is usually used to describe the water level in an unconfined aquifer; however, in this report the term water table describes the level of saturation in the soil profile within DRAINMOD.
A sensitivity analysis also was done with a selected number of model parameters to evaluate how simulated processes were affected by changes to the various parameters. The sensitivity analysis can provide information on what inputs may be the most important for collecting data because of the relative effect each input has on the simulated hydrology.

\section{Model Calibration}

DRAINMOD models simulated infiltration, subsurface drainage, and surface runoff from January 1, 2003, through December 31, 2018, in the three study areas in southeast North Dakota (study areas B, D, and S). Many of the processes simulated in the models are difficult to measure such as runoff from the fields and infiltration in the unsaturated zone. However, from April 2018 through October 2018, water-level data were collected from shallow groundwater wells installed near the wetlands in the study areas to evaluate how well the models performed in each of the study areas. This section describes the simulated hydrologic characteristics and calibration of the DRAINMOD models for the three study areas.

\section{Study Area B}

The calibrated DRAINMOD model for study area B showed the variability of hydrologic processes in the modeled field throughout the wide range of hydrologic conditions from January 1, 2003, through December 31, 2018 (figs. 17A-C). Runoff was typically generated during precipitation events with greater than $1 \mathrm{inch}$ of precipitation or during multiple events in close succession; for example, as observed in 2007 (figs.17A-B). Most of the larger runoff events during the simulation period occurred in March and April. In general, the discharge through the simulated subsurface drainage system occurred in the spring and early summer (April-June) most years, with little to no discharge later in the year. Some exceptions occurred in years that had late summer precipitation events, resulting in discharge from the drainage system during the fall (September through November) such as in 2013 and 2016. Discharge from the subsurface drainage ranged from 0 to 6.3 gallons per minute ( $\mathrm{gal} / \mathrm{min}$ ) during the simulation period (fig. 17C). During the calibration period in 2018, discharge only occurred in April and May with a maximum discharge of $1.7 \mathrm{gal} / \mathrm{min}$ (fig. 17C).

Simulated daily water table depths were compared to water table depths measured at two locations (sites BGW1 and BGW2; fig. 3). The two measurement sites were near the wetlands in the study area and not in the field being simulated by DRAINMOD. Consequently, the result was a model calibrated to approximate the patterns of fluctuations measured in the groundwater wells rather than trying to exactly match daily water table depths because the wells may not completely reflect the processes occurring in the simulated field. Simulated water table depths did match the general pattern of the measured water table depths at sites BGW1 and BGW2 

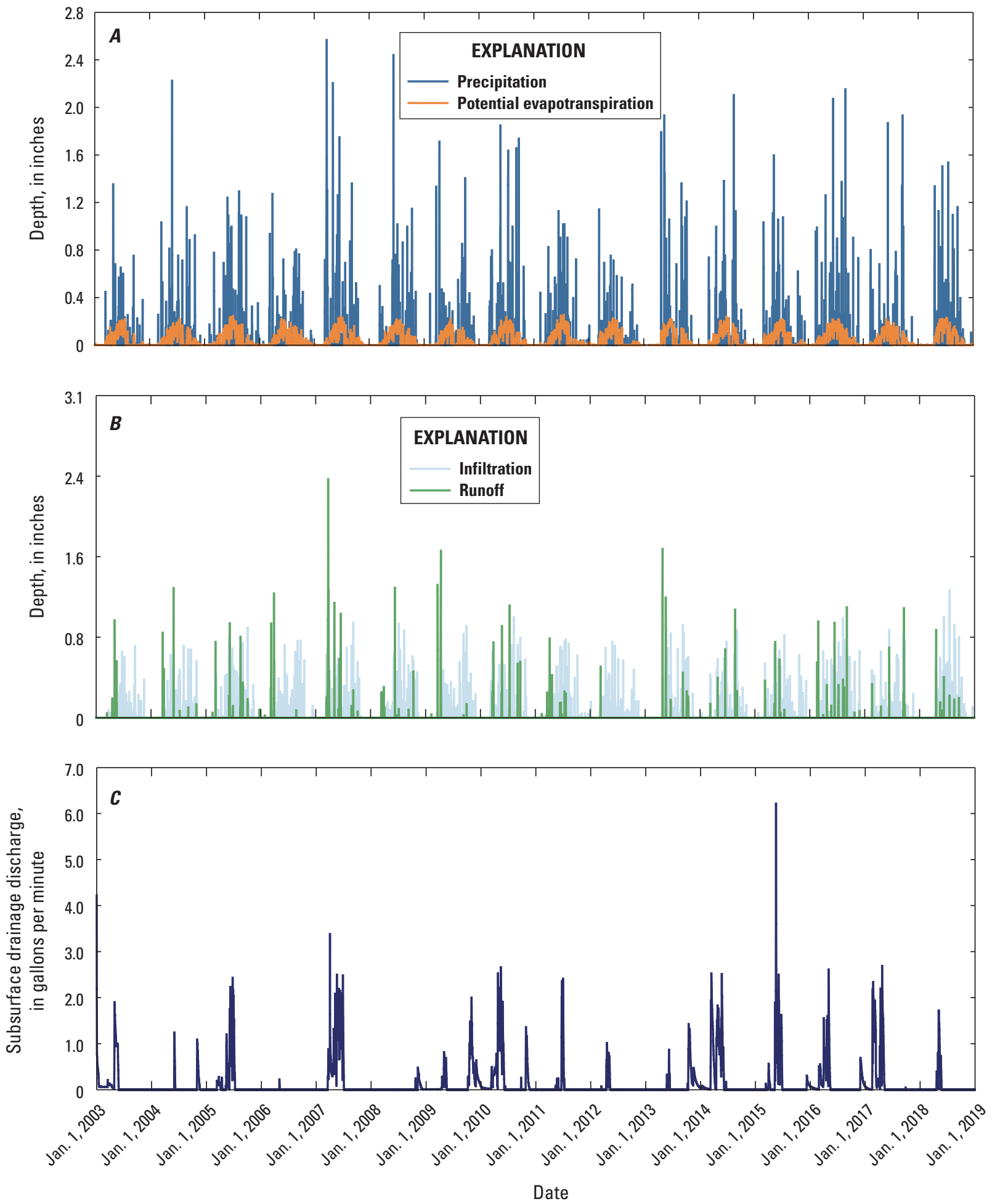

Figure 17. DRAINMOD model results for study area B from January 1, 2003, through December 31, 2018. A, Simulated precipitation and potential evapotranspiration; $B$, simulated infiltration and runoff; and $C$, simulated subsurface drainage discharge. 
but did not completely reflect the variability observed in the measured data (fig. 18B). Simulated water table depths did compare slightly better to water table depths measured at site BGW2, with an AME of $0.41 \mathrm{ft}$ and an RMSE of $0.52 \mathrm{ft}$, compared to site BGW1, with an AME of $0.44 \mathrm{ft}$ and an RMSE of $0.52 \mathrm{ft}$ (fig. 18B). Simulated water table depths were more similar to the pattern of measured water table depths in April through June and August through September, but underpredicted water table depths in July and October (fig. 18B). The locations of the wells within the study area may have caused the measured water table depths to be affected by interaction with the wetlands and, therefore, limiting the representation of the water depths and hydrologic processes in the fields. The lower variability of the simulated data relative to the measured data also may be due to the generalized soil-water properties in the model that do not fully capture the complexities of water movement in the subsurface in study area B. Variability in the water table depths also may be affected by the computation of ET in the model. The Thornwaithe method (Skaggs and others, 2012) was used in the model to estimate ET, and monthly correction factors were applied and adjusted during calibration. Estimated daily potential ET from a climate site using the Penman-Monteith method (Skaggs and others, 2012) may help improve model performance if such data were available near the modeled area.

\section{Study Area D}

The calibrated DRAINMOD model for study area D showed the variability of hydrologic processes in the modeled field throughout the wide range of hydrologic conditions from January 1, 2003, through December 31, 2018 (figs. 19A-C). Similar to the simulated results at study area B, runoff was typically generated during precipitation events with greater than 1 inch of precipitation or during multiple events in close succession (figs. 19A-B). Similar patterns also were seen in the pattern of runoff occurring in March and April for multiple years during the simulation period. In general, the discharge through the simulated subsurface drainage system occurred in the spring and early summer (April-June) most years, with little to no discharge later in the year (fig. 19C). Some exceptions were in years that had late summer precipitation events, resulting in fall (September-November) discharge from the drainage system, such as in 2013 and 2016. Discharge from the subsurface drainage ranged from 0 to $137 \mathrm{gal} / \mathrm{min}$ during the simulation period (fig. 19C). Although the DRAINMOD model used a uniform pipe size and a single outlet, the actual subsurface drainage system at study area $\mathrm{D}$ has three outlets with 10-inch mains, so the drainage discharge from the model might be underpredicted. However, no measured outlet discharge data are available to verify the results. During the calibration period in 2018, some discharge occurred in April and May, but the greatest discharge (maximum of $6.3 \mathrm{gal} / \mathrm{min}$ ) was in September and October (fig. 19C) because of several precipitation events that occurred in August and September.
Simulated daily water table depths were compared to measured water table depths at two locations (sites DGW1 and DGW2; fig. 4). The two measurement sites were near the wetlands in the study area and not in the field being simulated by DRAINMOD; therefore, the model was calibrated to approximate the patterns of fluctuations measured in groundwater wells that may be affected by the wetlands. Although the subsurface drainage system in study area D was the most complex among the three study areas and was simplified into a uniform system within DRAINMOD, simulated water table depths at study area D correlated better to measured water table depths compared to results from the model applications at the other two study areas. Simulated water table depths at both well sites (sites DGW1 and DGW2) compared similarly with measured water table depths, with an AME of $0.30 \mathrm{ft}$ and an RMSE of $0.37 \mathrm{ft}$ at site DGW1 and an AME of $0.29 \mathrm{ft}$ and an RMSE of $0.34 \mathrm{ft}$ at site DGW2 (fig. 20B). Simulated water table depths were similar to the pattern of measured water table depths in April through August, but overpredicted water table depths in September and October (fig. 20B). The locations of the wells within the study area may have caused the measured water table depths to be affected by interaction with the wetlands and, therefore, limiting the representation of the water depths and hydrologic processes in the fields. The estimation method used to generate potential ET also may have affected the deviations between simulated and measure water table depths.

\section{Study Area S}

The calibrated DRAINMOD model for study area $\mathrm{S}$ showed the variability of hydrologic processes in the modeled field throughout the wide range of hydrologic conditions from January 1, 2003, through December 31, 2018 (figs. 21A-C). Patterns in the runoff from this study area were similar to patterns in the other two study area models, with much of the runoff occurring in March and April for multiple years during the simulation period. In general, the discharge through the simulated subsurface drainage system also occurred in the spring and early summer (April-June) most years, with little to no discharge later in the year. Some exceptions occurred in years that had late summer precipitation events, resulting in discharge from the drainage system during the fall (SeptemberNovember) such as in 2009 and 2013. Discharge from the subsurface drainage ranged from 0 to $9.3 \mathrm{gal} / \mathrm{min}$ during the simulation period. During the 2018 calibration period, only a small amount of discharge occurred during 10 days in April, with a maximum discharge of $0.14 \mathrm{gal} / \mathrm{min}$ (fig. 21C).

Simulated daily water table depths were compared to measured water table depths measured at one site (SGW1; fig. 5). Although the subsurface drainage system in study area $\mathrm{S}$ was the simplest and the modeled field was the smallest among the three study areas, simulated water table depths at study area $\mathrm{S}$ did not correlate as well to measured water table depths compared to results from the model applications at the other two study areas. Simulated water table depths compared 

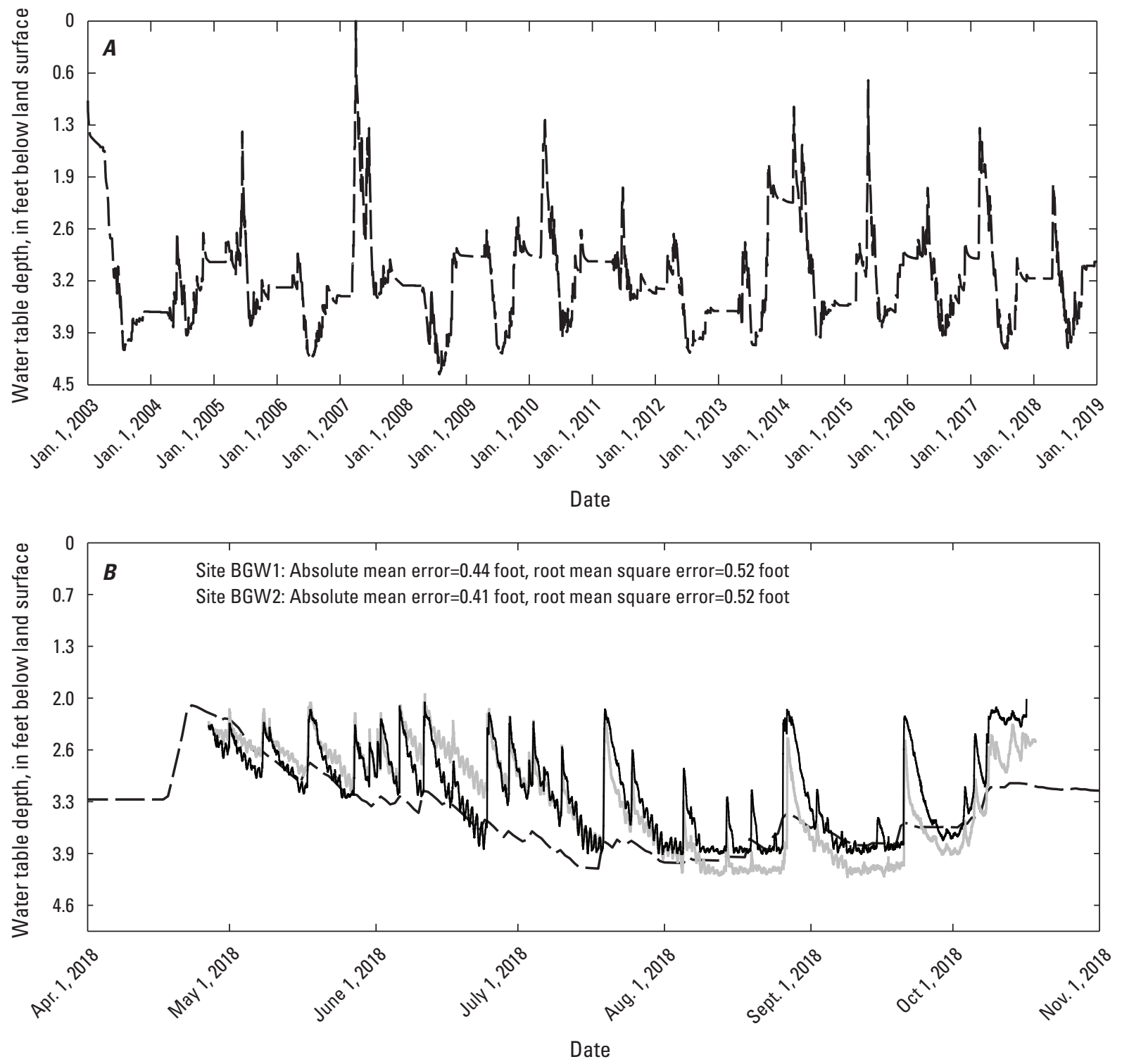

EXPLANATION

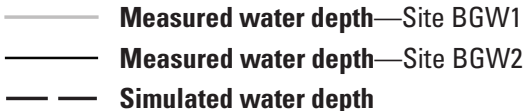

Figure 18. Water table depths in study area B. A, simulated water table depths for the simulation period of January 1 , 2003, through December 31, 2018; and B, simulated and measured water table depths, April 1, 2018, through October 31, 2018.

to measured water table depths determined from site SGW1 had an AME of $0.62 \mathrm{ft}$ and an RMSE of $0.74 \mathrm{ft}$ (fig. 22). Also, less measured data were available for comparison to simulated results because the groundwater well was dry for a substantial period during the April 2018 through October 2018 calibration period (fig. 22). Peaks in simulated water table depths generally coincided with peaks in the measured water table depths that occurred in July and October, but the simulated water table peak in April and May occurred earlier than the measured peak (fig. 22). Several factors such as the location of the groundwater well and estimation of potential ET mentioned previously for the models in the other study areas also could be relevant to the model developed at study area $\mathrm{S}$. The smaller field size in study area $\mathrm{S}$ also may have more dynamic hydrologic processes compared to the larger model areas in study areas B and D that were not adequately captured in the DRAINMOD model. 

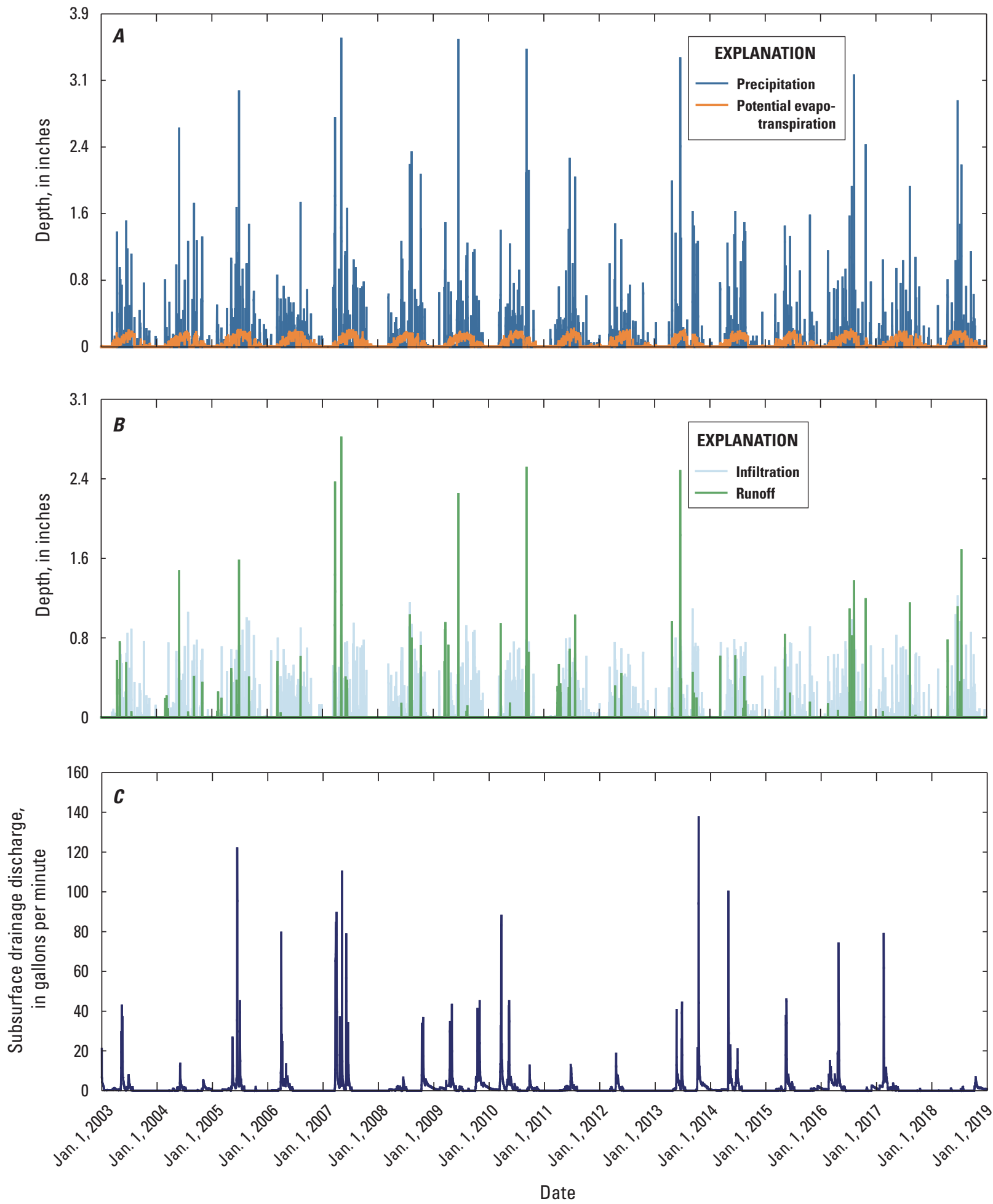

Figure 19. DRAINMOD model results for study area D from January 1, 2003, through December 31, 2018. A, Simulated precipitation and potential evapotranspiration; $B$, simulated infiltration and runoff; and $C$, simulated subsurface drainage discharge. 

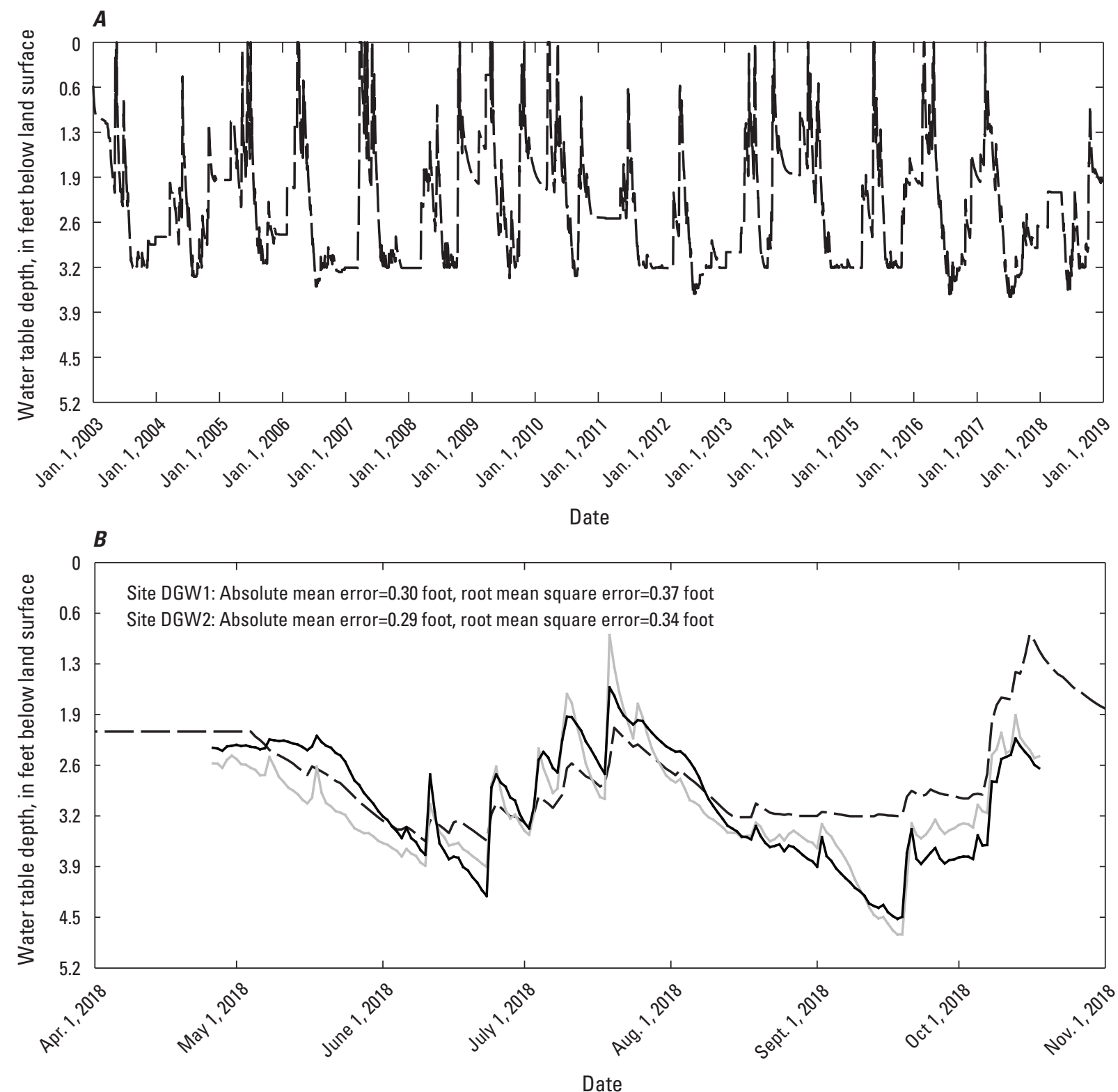

EXPLANATION

Measured water depth-Site DGW1

Measured water depth-Site DGW2

Simulated water depth

Figure 20. Water table depths in study area D. $A$, simulated water table depths for the simulation period of January 1 , 2003, through December 31, 2018; and B, simulated and measured water table depths, April 1, 2018, through 0ctober 31, 2018. 

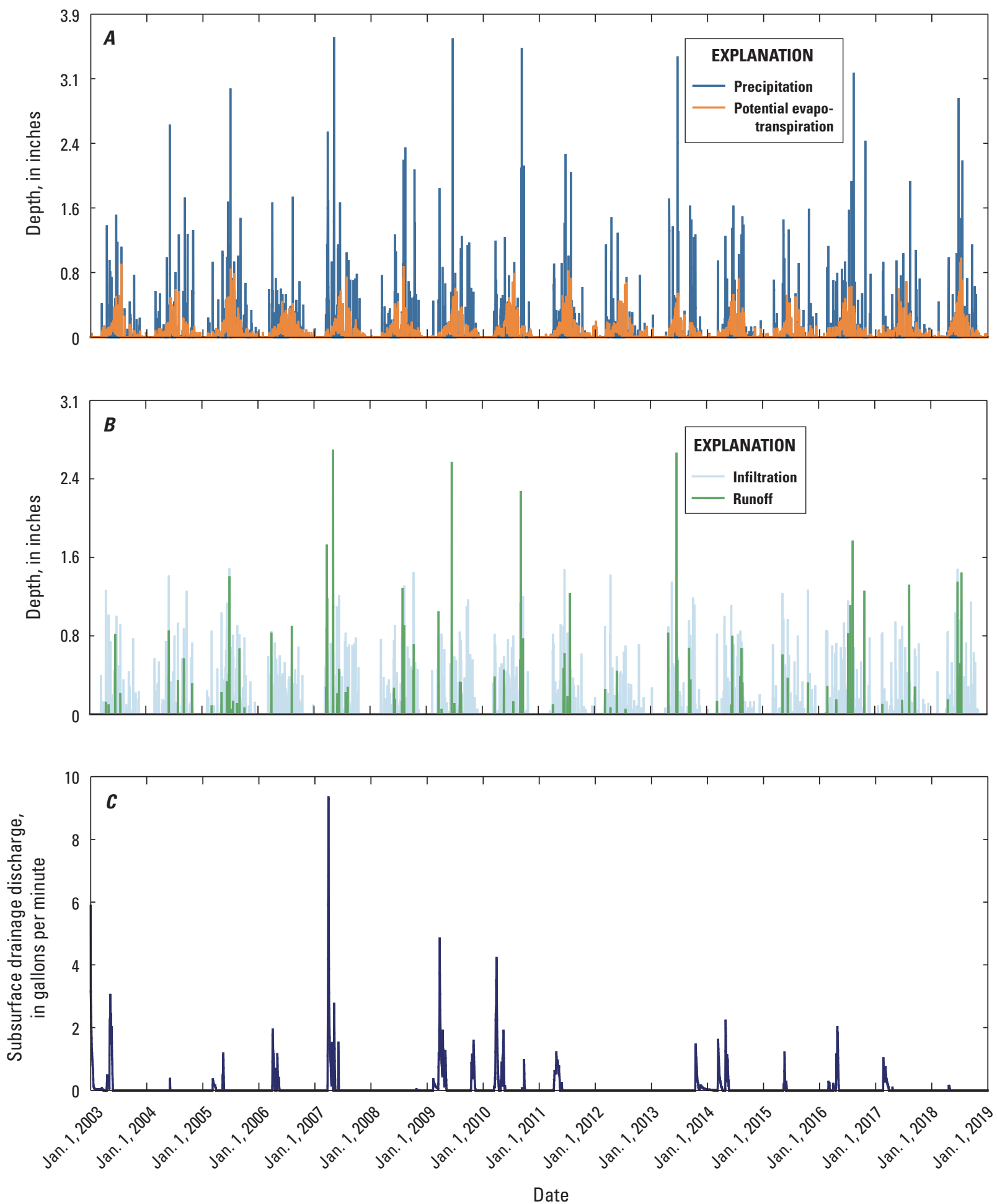

Figure 21. DRAINMOD model results for study area $S$ from January 1, 2003, through December 31, 2018. $A$, Simulated precipitation and potential evapotranspiration; $B$, simulated infiltration and runoff; and $C$, simulated subsurface drainage discharge. 

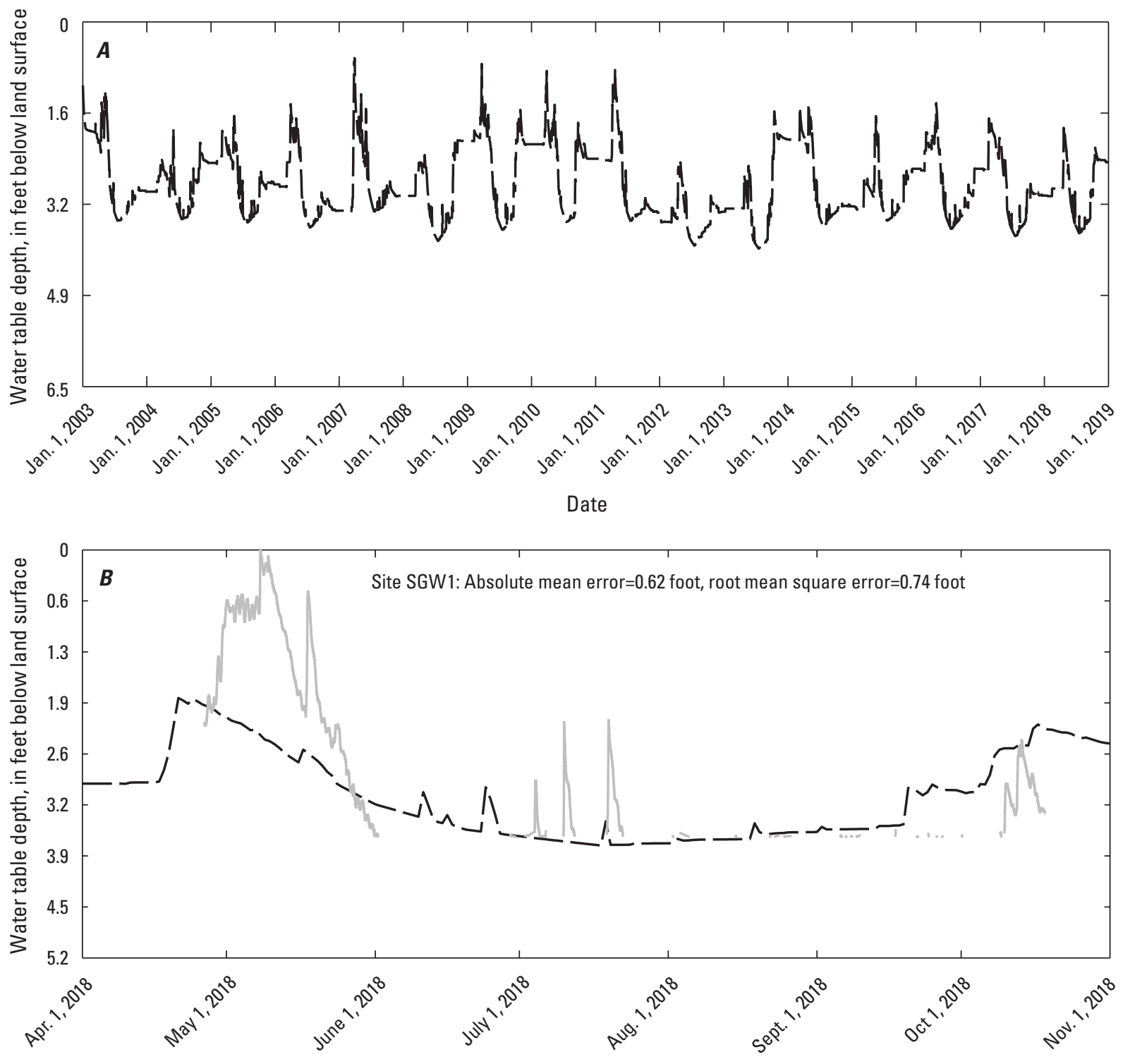

Date

EXPLANATION

Measured water depth

Simulated water depth

Figure 22. Water table depths in study area S. $A$, simulated water table depths for the simulation period of January 1 , 2003, through December 31, 2018; and B, simulated and measured water table depths, April 1, 2018, through October 31, 2018.

\section{Sensitivity Analysis}

Sensitivity analysis was done to evaluate parameters in the DRAINMOD model to determine which parameters have the most effect on simulated results. The sensitivity analysis also was used to evaluate model performance in describing hydrologic processes and to provide information on which parameters may be important for careful consideration during model development. Although many parameters are used in
DRAINMOD to describe hydrologic processes in a field with subsurface drainage, a subset of parameters was selected for a sensitivity analysis based on those parameters adjusted most frequently during calibration. The model developed and calibrated for study area D was selected for sensitivity analysis because the model for study area D had more simplifying assumptions in regard to the simulated subsurface drainage system compared to the models developed for study areas B and S (fig. 1). 
Sensitivity analysis completed on DRAINMOD for study area $\mathrm{D}$ determined that simulated water table depths were most sensitive to changes in ET, surface depressional storage, saturated lateral hydraulic conductivity, and the soil water content at saturation (table 10). Increasing and decreasing the ET correction factors by 50 percent changed the simulated water table depths by -2.38 and 1.34 inches from the calibrated values for the simulation period, respectively (table 10). The surface storage depth parameters control how much water can be stored in depressions on the surface before runoff can begin. Increasing and decreasing the surface storage (total and minimum) by 50 percent changed the simulated water table depths by -1.27 and 1.60 inches from the calibrated values for the simulation period, respectively. The lateral hydraulic conductivity controls how moisture in the soil profile moves laterally to the subsurface drainage in the model. Changes in the lateral hydraulic conductivity values for all the soil layers by 50 percent resulted in a 0.79 -inch and -1.52 -inch change in water table depth compared to the simulated model (table 10).

The model was least sensitive to changes in the diameter of the subsurface drainage pipe, drainage coefficient, and initial water table depth. The parameters were all increased and decreased by 50 percent but only changed the resulting simulated water table depths by 0.10 inch or less compared to the calibrated model in all cases (table 10). This result indicates that simplification of the subsurface system for the three study areas may not have had a substantial effect on the resulting simulated water table depth. Also, although the initial water table depth used in the model was arbitrary because no measured data were available, and the initial water table depth likely had a substantial effect at the beginning of the simulation, the initial water table depth, on average, did not have a substantial effect on the model results throughout the simulation period.

\section{Model Limitations}

The DRAINMOD model, similar to most models, provides a simplified estimation of the complex natural processes that control the hydrology of fields and wetlands, and because of assumptions made in the development and implementation of the models, the DRAINMOD model has inherent limitations. Similar to the SPAW field hydrology model, DRAINMOD is limited in its ability to simulate the heterogeneity of soil and crop properties across a field. Modeled fields were assumed to have homogeneous soil and crop properties. Soil properties can substantially change the output of the model because different soil properties will lead to increased or decreased runoff and infiltration. DRAINMOD also simulates water table fluctuations, but the model does not account for groundwater recharge. In the Prairie Pothole Region, groundwater discharge and recharge occur as parts of a complex and dynamic system (Winter, 2003). The attributes of wetlands that allow the wetlands to recharge groundwater are not completely understood, but the complexities of groundwater interactions with depressional wetlands makes the modeling of groundwater functions difficult. The recharge/discharge function of pothole wetlands has been determined to change seasonally, annually, and cyclically during wet and dry cycles (Winter, 2003). The only groundwater information entered for a DRAINMOD simulation is the starting depth of the water table. From the starting depth, the application simulates changes in the water table. The application can receive inputs for potential seepage, but groundwater recharge cannot be input into the system.

Another limitation is that DRAINMOD only simulates water table depth in one dimension (vertically) and does not simulate horizontal changes. So, to determine the volumetric discharge from a drainage system, the output (in inches) needs to be multiplied by a contributing area. Because the area of a modeled field is not explicitly simulated, larger errors could be introduced in the simulation of larger areas.

The model application also does not allow for changing of crops during a simulation. A single crop type must be chosen for the duration of the simulation. The only way to simulate crop rotation would be to break apart the simulation into pieces and adjust the crop information accordingly. This option, however, is not ideal because producers typically rotate crops on an annual basis, and in some years the field may be kept fallow or may be managed as part of a conservation-related program.

Another of the main limitations of the model application occurs with simulating frozen soil and snow cover during the winter. Early model applications were limited to warm seasons because of the lack of a freezing and thawing algorithm (Luo and others, 2000). Modifications, however, have been made to the model to include prediction of the soil temperature, snow accumulation, and melting processes (Zhao and others, 2000). However, the computations are somewhat simplistic and probably do not capture the complexities of freezing and thawing in the fall and spring in the northern climates such as in North Dakota. The algorithms may work adequately in more southern applications where the depth of frozen soil is minimal, but in areas like North Dakota, frozen soils can be more than $3 \mathrm{ft}$ deep. Therefore, the freezing and thawing computations probably do not adequately capture the freezing in the fall and thawing in the spring.

\section{Implications}

The SPAW and DRAINMOD model applications at the three study areas in southeast North Dakota adequately simulated the hydrologic processes for fields with subsurface drainage that are connected to adjacent wetlands. However, more measured data would be needed to fully evaluate the models throughout the range of climatic conditions. Although the simulation period (January 1, 2003, through December 31, 2018) covered a wide range of hydrologic conditions, the measured data only were available for April 2018 through October 2018. For future applications, having measured data for at least a 2-year period and ideally throughout a larger range of conditions would provide a better evaluation of the performance of the models. Some additional data that also would be useful for the development of 
Table 10. Results of sensitivity analysis for the DRAINMOD model for study area D, 2003-18.

\begin{tabular}{|c|c|c|}
\hline Parameter & $\begin{array}{l}\text { Input, in percent } \\
\text { change from } \\
\text { calibrated value }\end{array}$ & $\begin{array}{l}\text { Mean difference in } \\
\text { water table depth } \\
\text { (sensitivity test minus } \\
\text { calibrated value), } \\
\text { in inches }\end{array}$ \\
\hline \multirow{2}{*}{ Potential evapotranspiration correction factor } & +20 & -2.38 \\
\hline & -20 & 1.34 \\
\hline Drainage coefficient & -50 & -0.03 \\
\hline \multirow{2}{*}{ Surface and minimum depressional storage } & +50 & -1.27 \\
\hline & -50 & 1.60 \\
\hline \multirow{2}{*}{ Saturated lateral hydraulic conductivity values } & +50 & 0.79 \\
\hline & -50 & -1.52 \\
\hline Initial water table depth & -50 & 0.07 \\
\hline 6-inch diameter drain (calibrated value, 4-inch drain) & -- & 0.09 \\
\hline 8-inch diameter drain (calibrated value, 4-inch drain) & -- & 0.08 \\
\hline
\end{tabular}

the SPAW and DRAINMOD models include soil moisture, soil temperature, soil core, and additional groundwater-level data in the field portion of the model area. Although the groundwater interaction with the field hydrology model portion of SPAW is a simplistic computation, the sensitivity analysis described in this report indicated that the model can be sensitive to changes in the groundwater parameters. Although measuring discharge can be difficult depending on the configuration of the drain outlet, measured discharge from the subsurface drainage system also would be useful for the development and calibration of the DRAINMOD model in future applications. For future applications of SPAW, having complete and accurate data for the configuration of the wetlands also is important to fully develop the depth-capacity curve input to the pond hydrology portion of the model. For the applications described in this report, lidar data and some survey data were used and provided adequate estimations of the wetland depth capacity; however, for larger wetlands with greater depth, this method may not capture the full range of depth for the wetland.

Because of SPAW's lack of computations to estimate subsurface drainage, DRAINMOD was evaluated in this report to be used in conjunction with SPAW to account for subsurface drainage discharge from a field. However, given the simplistic input to SPAW, the daily output generated by DRAINMOD did not add much value to the simulation of the wetlands in the three study areas. If perhaps another model was used to simulate the field wetland hydrology that could use a daily input, then the DRAINMOD simulation may be more useful for capturing the variability of the discharge from the subsurface drainage system.
Given the limitations of SPAW and DRAINMOD, the complexity of the system to be simulated warrants careful consideration for future applications. For example, the SPAW model has no flow-routing capability, so if the modeled area is affected by surface drainage features, SPAW may not fully capture the hydrologic processes in the area. Also, if fields in the modeled area have a strong interaction with shallow groundwater, the routines in DRAINMOD and the field hydrology and pond model portions of SPAW will likely be limited in simulating the variability. For DRAINMOD, the complexity of the subsurface drainage system and the area affected by the subsurface drainage would affect how effectively the model would simulate the hydrology of the model area. DRAINMOD does not specify a drainage area in the model and assumes uniform soil and crop properties. Therefore, if modeled fields have a surface drainage system, heterogeneous soil properties, or subsurface drainage with a complex configuration throughout multiple fields, these factors may limit how well the model simulates the hydrologic conditions in the modeled area.

\section{Summary}

Proper identification of wetlands, along with a better understanding of the hydrology of mitigated wetlands, are needed to assist with conservation efforts aimed at maintaining the productivity as well as ecological function (wetland mitigation) of agricultural lands. The U.S. Geological Survey, in cooperation with the U.S. Department of Agriculture Natural Resources Conservation Service, completed a study to evaluate two models for simulating hydrologic conditions 
in fields with subsurface drainage to mitigated wetlands at several sites in North Dakota. The two models were selected for evaluation at sites in Barnes, Dickey, and Sargent Counties in North Dakota - the Soil-Plant-Atmosphere-Water (SPAW) and DRAINMOD models, were evaluated as possible tools for water resource managers to use for designing wetland mitigation projects in the area in the future.

The SPAW model simulates the daily hydrologic water budgets of agricultural landscapes by two linked routines, one for farm fields (field hydrology) and one for impoundments such as wetlands and ponds (pond model). Field hydrology is represented by precipitation; temperature; evapotranspiration; interacting soil layers; and annual crop growth with management options for rotations, irrigation, and fertilization. Simulations estimate daily vertical, one-dimensional water budget with soil-water profiles of all primary hydrologic processes such as runoff, infiltration, storage, and seepage to groundwater. Pond hydrology simulations provide water budgets by multiple inflow and outflow processes for impoundments that have agricultural fields or operations as a water source.

The DRAINMOD model was used in conjunction with the SPAW model because although the SPAW model can be used to simulate the hydrology of small drainage basins containing wetlands, the SPAW model does not contain routines to simulate drainage, either subsurface drainage or surface (drainage ditches), that can directly affect the wetland hydrology. The wetlands in the study areas in this report are all downstream from and adjacent to drained agricultural fields.

The SPAW model developed for study area B included five modeled fields in the field hydrology portion of SPAW that contributed inflow to one wetland simulated in the pond model portion of SPAW. Generally, simulated runoff and infiltration were greatest in years with the most precipitation in 2010, 2013, and 2016 during the simulation period (January 1, 2003, through December 31, 2018). Runoff generally occurred in response to multiple precipitation events in close succession or during prolonged events of several days when the simulated soil profile became saturated.

Simulated wetland water depths were most similar to water depths measured at site BWET1, with an absolute mean error of 0.10 foot and a root mean square error of 0.14 foot. Site BWET2 had slightly larger errors, with an absolute mean error of 0.22 foot and root mean square error of 0.28 foot. Simulated water depths were similar to the pattern of measured water depths at BWET1 and BWET2 from about midApril 2018 through about mid-September 2018, but overpredicted water depths in the fall from about mid-September 2018 through about mid-October 2018.

The SPAW model developed for study area D included six model fields in the field hydrology portion of SPAW that contributed inflow to five wetlands connected in series in the pond model portion of SPAW. Patterns in simulated runoff and infiltration were similar to the simulated results from study area $\mathrm{B}$; however, precipitation was distributed slightly different, resulting in the greatest simulated runoff in 2007, 2011, and 2013 and the greatest infiltration in 2005, 2013, and 2016 during the simulation period. The least runoff and infiltration were in 2006, 2012 and 2017. Simulated water depths compared relatively well to water depths in the five wetlands, with the absolute mean error ranging from 0.17 foot (DWET1) to 0.39 foot (DWET2), and the root mean square error ranging from 0.28 foot (DWET1) to 0.56 foot (DWET5).

The SPAW model developed for study area S included one modeled field in the field hydrology portion of SPAW that contributed inflow to one wetland in the pond model portion of SPAW. Patterns in simulated runoff and infiltration were similar to the simulated results from the other two study areas; however, precipitation was distributed slightly different. The greatest simulated runoff was in 2004, 2007, and 2016, but the greatest infiltration was in 2005, 2010, and 2011 during the simulation period.. The least runoff was in 2006, 2009, and 2014 and the least infiltration was in 2006, 2012, and 2015. Among the SPAW models developed for the three study areas, the model for study area S showed the best comparison between simulated and measured water depths, with an absolute mean error of 0.06 foot and a root mean square error of 0.10 foot.

DRAINMOD models were developed and calibrated at the three study areas to evaluate how the models simulated field-scale hydrologic characteristics for fields affected by subsurface drainage from January 1, 2003, through December 31, 2018. DRAINMOD models also provided inflow from subsurface drainage discharge to the SPAW models for simulating water depths in wetlands in the study areas. Measured water table data were collected in shallow groundwater wells in each study area for comparison to simulated water table depths from April 2018 through October 2018.

The calibrated DRAINMOD model for study area B showed the variability of hydrologic processes in the modeled field throughout the wide range of hydrologic conditions from January 1, 2003, through December 31, 2018. Runoff was typically generated during precipitation events with greater than 1 inch of precipitation or during multiple events in close succession; for example, as observed in 2007. Most of the larger runoff events during the simulation period occurred in March and April. In general, the discharge through the modeled subsurface drainage system occurred in the spring and early summer (April-June) most years, with little to no discharge later in the year. Simulated water table depths matched the general pattern of the measured water table depths at sites BGW1 and BGW2 but did not completely reflect the variability observed in the measured data. Simulated water table depths did compare slightly better to water table depths measured at site BGW2, with an absolute mean error of 0.41 foot and a root mean square error of 0.52 foot compared to site BGW1, with an absolute mean error of 0.44 foot and a root mean square error of 0.52 foot.

The calibrated DRAINMOD model for study area D showed the variability of hydrologic processes in the modeled field similar to the simulated results at study area B. In general, the discharge through the modeled subsurface 
drainage system occurred in the spring and early summer (April-June) most years, with little to no discharge later in the year. Although the subsurface drainage system in study area $\mathrm{D}$ was the most complex among the three study areas and was simplified into a uniform system within DRAINMOD, simulated water table depths at study area D correlated better to measured water table depths compared to results from the model applications at the other two study areas. Simulated water table depths had an absolute mean error of 0.30 foot and a root mean square error of 0.37 foot at site DGW1 and an absolute mean error of 0.29 foot and a root mean square error of 0.34 foot at site DGW2.

The calibrated DRAINMOD model for study area S showed similar patterns in the runoff as for the other two study area models, with much of the runoff occurring in March and April multiple years during the simulation period. In general, the discharge through the modeled subsurface drainage system also occurred in the spring and early summer (AprilJune) most years, with little to no discharge later in the year. Although the subsurface drainage system in study area $\mathrm{S}$ was the simplest and the modeled field was the smallest among the three study areas, simulated water table depths at study area S did not correlate as well to measured water table depths than compared to results from the model applications at the other two study areas. Simulated water table depths compared to measured water table depths determined from site SGW1 had an absolute mean error of 0.62 foot and a root mean square error of 0.74 foot.

The SPAW and DRAINMOD model applications at the three study areas in southeast North Dakota adequately simulated the hydrologic processes for fields with subsurface drainage that are connected to adjacent wetlands. However, more measured data were needed to fully evaluate the models throughout the range of climatic conditions. Although the simulation period covered a wide range of hydrologic conditions, the measured data only were available for April 2018 through October 2018. Because of SPAW's lack of computations to estimate subsurface drainage, DRAINMOD was evaluated in this report to be used in conjunction with SPAW to account for subsurface drainage discharge from a field. However, given the simplistic input to SPAW, the daily output generated by DRAINMOD did not add much value to the simulation of the wetlands in the three study areas. Given the limitations of the two models, the complexity of the system to be modeled must be considered carefully in future applications. For example, the SPAW model has no flow-routing capability, so if the modeled area is affected by surface drainage features, SPAW may not fully capture the hydrologic processes in the area. Also, if fields in the modeled area have a strong interaction with shallow groundwater, the routines in DRAINMOD and the field hydrology and pond model portions of SPAW will likely be limited in simulating the variability.

\section{References Cited}

Andersen, D.S., Burns, R.T., Moody, L.B., Helmers, M.J., Horton, R., and Pederson, C.H., 2010, Use of the soilplant-air-water model to predict hydraulic performance of vegetative treatment areas controlling open lot runoff: Iowa State University Agricultural and Biosystems Engineering Publications, accessed December 2016 at http://lib.dr.ia state.edu/cgi/viewcontent.cgi article $=1578 \&$ context $=$ abe eng_pubs.

Carter, R.W., 1957, Computation of peak discharge at culverts: U.S. Geological Survey Circular 376, 25 p., accessed August 2020 at https://pubs.er.usgs.gov/publication/cir376.

Chow, V.T., 1959, Open Channel Hydraulics: New York, N.Y., McGraw-Hill, 680 p.

Cunningham, W.L., and Schalk, C.W., comps., 2011, Groundwater technical procedures of the U.S. Geological Survey: U.S. Geological Survey Techniques and Methods, book 1, chap. A1, 151 p. [Also available at https://doi.org/ 10.3133/tm1A1.]

Dahl, T.E., 2014, Status and trends of prairie wetlands in the United States 1997 to 2009: Washington, D.C., U.S. Fish and Wildlife Service; accessed April 2021 at https://www.fws.gov/wetlands/Status-And-Trends/ index.html.

Debre, S., Abbeney-Mickson, S., Sabil, E.B., and Yangyurou, M., 2011, Use of the SPAW model to simulate the water balance components of the ARC-Kpong irrigation tank: Journal of the Ghana Institution of Engineers, v. 8, p. 39-46.

Ernst, L.F., 1975, Formulae for groundwater flow in areas with subirrigation by means of open conduits with a raised water level-Misc. reprint 178: Wageningen, The Netherlands, Institute for Land and Water Management Research.

Freeze, R.A., and Cherry, J.A., 1979, Groundwater: Englewood Cliffs, N.J., Prentice-Hall, Inc., 624 p.

Fouss, J.L., Bengtson, R.L., and Carter, C.E., 1987, Simulating subsurface drainage in the lower Mississippi valley with DRAINMOD: American Society of Agricultural Engineers, v. 30, no. 6, p. 1679-1688. [Also available at https://doi.org/ 10.13031/2013.30622.]

Gayle, G.A., Skaggs, R.W., and Carter, C.E., 1985, Evaluation of a water management model for a Louisiana sugar cane field: Journal of the American Society of Sugar Cane Technologists, v. 4, p. 18-28.

Golden Software, 2019, Surfer version 17: accessed February 21, 2019, at https:/www.goldensoftware.com/ products/surfer. 
Green, W.H., and Ampt, G., 1911, Studies of soil physics, part I-The flow of air and water through soils: Journal of Agricultural Science, v. 4, p. 11-24.

Hendrosusanto, R., Feyen, J., and Dierickx, W., 1987, The use of simulation models to evaluate the performance of subsurface drainage system, in Proceedings of the Third International Workshop on Land Drainage, Columbus, Ohio, December 7-11, 1987: Columbus, Ohio, Ohio State University, p. A67-A76, accessed October 19, 2020, at https://library.wur.nl/WebQuery/titel/746887.

High Plains Regional Climate Center, 2020, Data services: accessed February 26, 2020, at https://hprcc.unl.edu/onlined ataservices.php\#data.

Hill, A.J., and Neary, V.S., 2009, Hydrologic response of a forested sinkhole wetland to different land management scenarios: Journal of Environmental Hydrology, v. 17, paper 5, $18 \mathrm{p}$. [Also available at http://www.hydroweb.com/protect/ pubs/jeh/jeh2009/hill.pdf.]

Hooghoudt, S.B., 1940, General consideration of the problem of field drainage by parallel drains, ditches, watercourses, and channels-Publ. no.7 in the series Contribution to the knowledge of some physical parameters of the soil (titles translated from Dutch): Groningen, The Netherlands, Bodemkundige Instituut.

Jin, C.X., and Sands, G.R., 2003, The long-term scale hydrology of subsurface drainage systems in a cold climate: American Society of Agricultural Engineers, v. 46, no. 4, p. 1011-1021.

Luo, W., Skaggs, R.W., and Chescheir, G.M., 2000, DRAINMOD modifications for cold conditions: American Society of Agricultural and Biological Engineers, v. 43, no. 6, p. 1569-1582. [Also available at https://doi.org/10.13031/ 2013.3057.]

Luo, W., Skaggs, R.W., Madani, A., Cizikci, S., and Mavi, A., 2001, Predicting field hydrology in cold conditions with DRAINMOD: American Society of Agricultural Engineers, v. 44 , no. 4 , p. $825-834$.

Luthin, J.N., ed., 1957, Drainage of Agricultural Lands v. 7: American Society of Agronomy, 611 p.

McMahon, P.C., Mostaghimi, S., and Wright, F.S., 1988, Simulation of corn yield by a water management model for a coastal plains soil in Virginia: American Society of Agricultural and Biological Engineers, v. 31, no. 3, p. 734-742. [Also available at https://doi.org/10.13031/ 2013.30776.]
Millhollon, E.P., Rodrigue, P.B., Rabb, J.L., Martin, D.F., Anderson, R.A., and Dans, D.R., 2009, Designing a constructed wetland for the detention of agricultural runoff for water quality improvement: Journal of Environmental Quality, v. 38, p. 2458-2467. [Also available at https://doi.org/10.2134/jeq2008.0526.]

Mualem, Y., 1976, A new model predicting the hydraulic conductivity of unsaturated porous media: Water Resources Research, v. 12 , no. 3, p. 513-522. [Also available at https://doi.org/10.1029/WR012i003p00513.]

National Archives, 2016, Federal Register, Executive Order 11990 - Protection of wetlands: accessed January 6, 2020, at https://www.archives.gov/federal-register/codification/ executive-order/11990.html.

National Cooperative Soil Survey, 2019, Soil characterization database, 2019: accessed September 18, 2019, at https://ncs slabdatamart.sc.egov.usda.gov/.

National Weather Service, 2021, NOWData-NOAA online weather data: accessed February 26, 2021, at https://w2.we ather.gov/climate/xmacis.php?wfo $=$ fgf.

North Carolina State University, 2020, Agricultural water management: accessed January 6, 2020, at https://www.bae .ncsu.edu/agricultural-water-management/drainmod/ download/.

North Dakota Agricultural Weather Network, 2019, Daily weather data: accessed May 5, 2019, at https://ndawn.ndsu. nodak.edu/weather-data-daily.html.

North Dakota State Water Commission, 2019, Map servicesLidar data: accessed May 10, 2019, at https://www.s wc.nd.gov/info_edu/map_data_resources/mapservices.html.

Omernik, J.M., and Griffith, G.E., 2014, Ecoregions of the conterminous United States-Evolution of a hierarchical spatial framework: Environmental Management, v. 54, p. 1249-1266. [Also available at https://doi.org/10.1007/ s00267-014-0364-1.]

Rogers, J.S., 1985, Water management model evaluation for shallow sandy soils: American Society of Agricultural and Biological Engineers, v. 28, no. 3, p. 785-790. [Also available at https://doi.org/10.13031/2013.32338.]

Rydlund, P.H., Jr., and Densmore, B.K., 2012, Methods of practice and guidelines for using survey-grade Global Navigation Satellite Systems (GNSS) to establish vertical datum in the United States Geological Survey: U.S. Geological Survey Techniques and Methods, book 11, chap. D1, 102 p., with appendixes. [Also available at https://doi.org/10.3133/tm11D1.] 
Salazar, O., Wesström, I., Youssef, M.A., Skaggs, R.W., and Joel, A., 2009, Evaluation of the DRAINMOD-N II model for predicting nitrogen losses in a loamy sand under cultivation in south-east Sweden: Agricultural Water Management, v. 96, no. 2, p. 267-281. [Also available at https://doi.org/ 10.1016/j.agwat.2008.08.008.]

Saxton, K.E., 2002, Soil-plant-atmosphere-water field \& pond hydrology reference manual: U.S. Department of Agriculture, accessed July 29, 2020, at https://hrsl.ba.ars .usda.gov/SPAW/SPAW\%20Reference\%20Manual/ Index.htm.

Saxton, K.E., and Willey, P.H., 2004, Soil-plant-atmospherewater field \& pond hydrology users manual: U.S. Department of Agriculture, accessed July 29, 2020, at https://hrsl.ba.ars.usda.gov/SPAW/SPAW\%20Users \%20Manual/Index.htm.

Schaap, M.G., Leij, F.J., and van Genuchten, M.T., 2001, Rosetta-A computer program for estimating soil hydraulic parameters with hierarchical pedotransfer functions: Journal of Hydrology (Amsterdam), v. 251, no. 3-4, p. 163-176. [Also available at https://doi.org/10.1016/ S0022-1694(01)00466-8.]

Skaggs, R.W., 1978, A water management model for shallow soils: Water Resources Institute of the University of North Carolina, Report 134, 200 p., accessed October 19, 2020, at: https://repository.lib.ncsu.edu/handle/1840.4/1618.

Skaggs, R.W., 1980, DRAINMOD reference report: Fort Worth, Tex., U.S. Department of Agriculture, Soil Conservation Service, South National Technical Center, accessed April 2021 at https://www.bae.ncsu.edu/ agricultural-water-management/drainmod/manuals/.

Skaggs, R.W., Fausey, N.R., and Nolte, B.H., 1981, Water management model evaluation for north central Ohio: American Society of Agricultural and Biological Engineers, v. 24, no. 4, p. 922-928. [Also available at https://doi.org/ 10.13031/2013.34365.]

Skaggs, R.W., Nassehzadeh-Tabrizi, A., and Foster, G.R., 1982, Subsurface drainage effects on erosion: Journal of Soil and Water Conservation, v. 37, no. 3, p. 167-172.

Skaggs, R.W., Youssef, M.A., and Chescheir, G.M., 2012, DRAINMOD - Model use, calibration and validation: American Society of Agricultural and Biological Engineers, v. 55, no. 4, p. 1509-1522.

Tangen, B.A., and Finocchiaro, R.G., 2017, A case study examining the efficacy of drainage setbacks for limiting effects to wetlands in the Prairie Pothole Region, USA: Journal of Fish and Wildlife Management, v. 8, no. 2, p. 513-529. [Also available at https://doi.org/10.3996/ 022017-JFWM-012.]
Taylor, G.S., and Luthin, J.N., 1978, A model for coupled heat and moisture transfer during soil freezing: Canadian Geotechnical Journal, v. 15, no. 4, p. 548-555. [Also available at https://doi.org/10.1139/t78-058.]

Thorp, K.R., Youssef, M.A., Jaynes, D.B., Malone, R.W., and Ma, L., 2009, DRAINMOD-N II-Evaluated for an agricultural system in Iowa and compared to RZWQM-DSSAT: American Society of Agricultural and Biological Engineers, v. 52, no. 5, p. 1557-1573. [Also available at https://doi.org/ 10.13031/2013.29144.]

U.S. Army Corps of Engineers, 1987, Corps of Engineers wetlands delineation manual: Wetlands Research Program Technical Report Y-87-1, 143 p., accessed April 2021 at h ttps://www.lrh.usace.army.mil/Portals/38/docs/USACE $\% 2$ 087\%20Wetland\%20Delineation\%20Manual.pdf.

U.S. Department of Agriculture, 1972, Chapter 7 Hydrologic soil groups: Part 630 Hydrology National Engineering Handbook, 5 p., accessed April 2021 at https://directiv es.sc.egov.usda.gov/OpenNonWebContent.aspx? content= 22526.wba.

U.S. Department of Agriculture, 1986, Provisions of the Food Security Act 1985: Economic Research Service, Agricultural Information Bulletin No. AIB-498, 116 p., accessed April 2021 at https://www.ers.usda.gov/ publications/pub-details/?pubid $=42003$.

U.S. Department of Agriculture, 2020a, National Agricultural Statistics Service CropScape-Cropland Data Layer: accessed June 3, 2020, at https://nassgeodata.gmu.edu/ CropScape/

U.S. Department of Agriculture, 2020b, Web Soil Survey: accessed June 3, 2020, at https://websoilsurvey.sc.egov .usda.gov/App/HomePage.htm.

U.S. Geological Survey, 2020a, USGS water data for the Nation: U.S. Geological Survey National Water Information System database, accessed June 8, 2020, at https://doi. org/10.5066/F7P55KJN.

U.S. Geological Survey, 2020b, USGS StreamStats: accessed June 2, 2020, at https://streamstats.usgs.gov/ss/.

Valder, J.F., Carter, J.M., Robinson, S.M., Laveau, C.D., and Petersen, J.A., 2018, Quality-assurance plan for groundwater activities, U.S. Geological Survey Dakota Water Science Center: U.S. Geological Survey Open-File Report 2018-1103, 28 p. [Also available at https://doi.org/10.3133/ ofr20181103.]

van der Valk, A.G., 2005, Water-level fluctuations in North American prairie wetlands: Hydrobiologia, v. 539, no. 1, p. 171-188. [Also available at https://doi.org/10.1007/ s10750-004-4866-3.] 
van Genuchten, M.T., 1980, A closed-form equation for predicting the hydraulic conductivity of unsaturated soils: Soil Science of American Journal, v. 44, no. 5, p. 892-898. [Also available at https://doi.org/10.2136/sssaj1980.03615995004 400050002x.]

Wang, X., Youssef, M.A., Skaggs, R.W., Atwood, J.D., and Frankenberger, J.R., 2005, Sensitivity analyses of the nitrogen simulation model: DRAINMOD-N II: American Society of Agricultural Biological Engineers, v. 48, no. 6, p. 2205-2212. [Also available at https://doi.org/10.13031/ 2013.20106.]

Winter, T.C., ed., 2003, v. 1675. Hydrological, chemical, and biological characteristics of a prairie pothole wetland complex under highly variable climate conditions-the Cottonwood Lake area, east-central North Dakota, U.S. Geological Survey Professional Paper, 109 p. [Also available at https://doi.org/10.3133/pp1675.]

Zhao, S., Gupta, S.C., Huggins, D.R., and Moncrief, J.F., 2000, Predicting subsurface drainage, corn yield, and nitrate nitrogen losses with DRAINMOD-N: Journal of Environmental Quality, v. 29, no. 3, p. 817-825. [Also available at https://doi.org/10.2134/jeq2000.00472425002 900030018x.] 


\section{Appendix 1. Additional Model Parameters Used in SPAW Model Applications at Study Areas B, D, and S}

Table 1.1. Soil properties used for modeled fields in the SPAW model for study area B in Barnes County, North Dakota.

[Soil description in parentheses from U.S. Department of Agriculture, 2020]

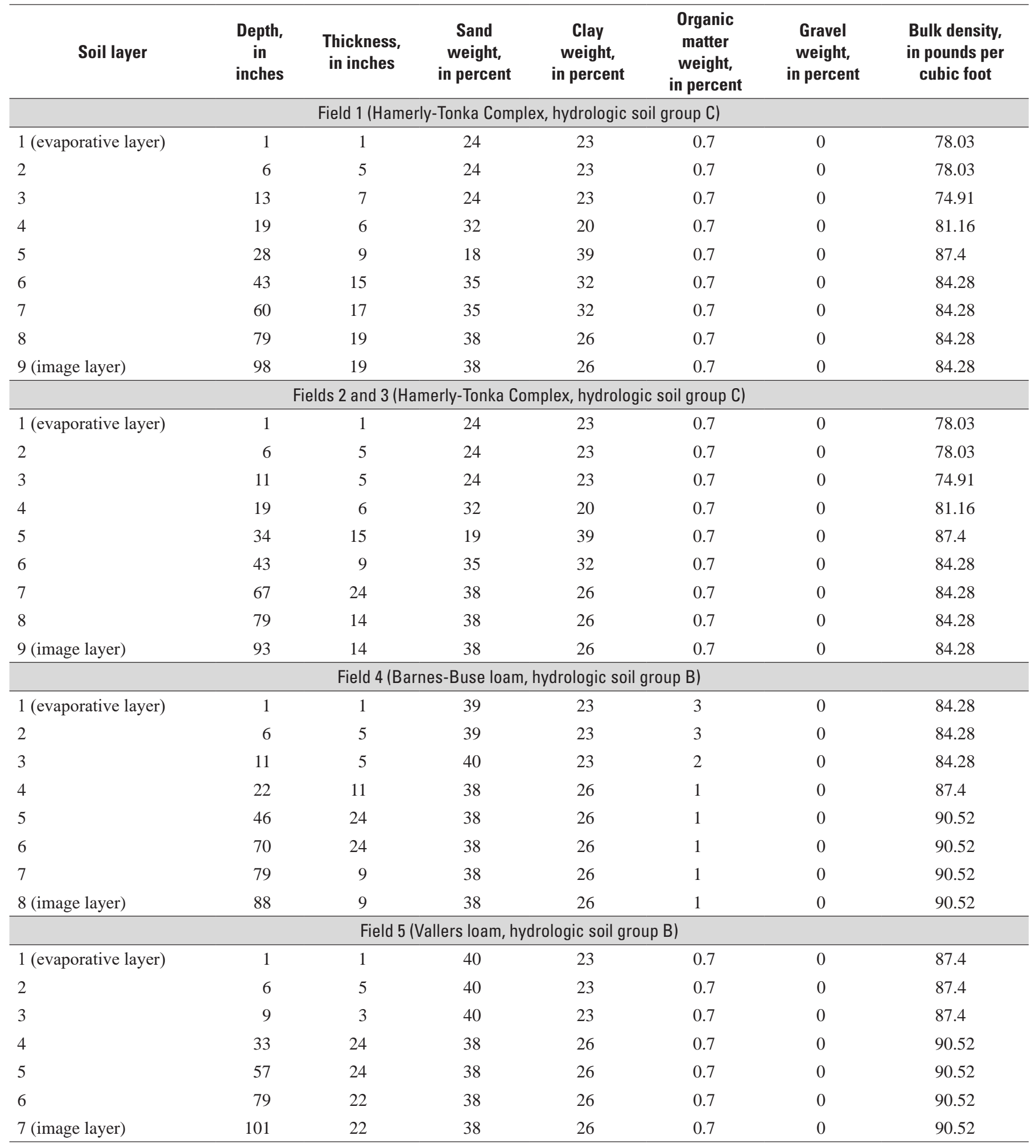


Table 1.2. Soil properties used for modeled fields in the SPAW model for study area D in Dickey County, North Dakota.

[Soil description in parentheses from U.S. Department of Agriculture, 2020]

\begin{tabular}{|c|c|c|c|c|c|c|c|}
\hline Soil layer & $\begin{array}{l}\text { Depth, } \\
\text { in } \\
\text { inches }\end{array}$ & $\begin{array}{l}\text { Thickness, } \\
\text { in inches }\end{array}$ & $\begin{array}{c}\text { Sand } \\
\text { weight, } \\
\text { in percent }\end{array}$ & $\begin{array}{l}\text { Clay weight, } \\
\text { in percent }\end{array}$ & $\begin{array}{c}\text { Organic } \\
\text { matter } \\
\text { weight, } \\
\text { in percent }\end{array}$ & $\begin{array}{c}\text { Gravel } \\
\text { weight, } \\
\text { in percent }\end{array}$ & $\begin{array}{c}\text { Bulk } \\
\text { density, } \\
\text { in pounds per } \\
\text { cubic foot }\end{array}$ \\
\hline 1 (evaporative layer) & 1 & 1 & 39 & 23 & 3 & 0 & 84.28 \\
\hline 2 & 6 & 5 & 39 & 23 & 3 & 0 & 84.28 \\
\hline 4 & 22 & 11 & 38 & 26 & 1 & 0 & 87.4 \\
\hline 5 & 46 & 24 & 38 & 26 & 1 & 0 & 90.52 \\
\hline 6 & 70 & 24 & 38 & 26 & 1 & 0 & 90.52 \\
\hline 7 & 79 & 9 & 38 & 26 & 1 & 0 & 90.52 \\
\hline 2 & 6 & 5 & 39 & 23 & 1.9 & 0 & 84.28 \\
\hline 3 & 10 & 4 & 40 & 23 & 0.9 & 0 & 84.28 \\
\hline 4 & 21 & 11 & 38 & 26 & 0.6 & 0 & 87.4 \\
\hline 5 & 37 & 16 & 38 & 26 & 0.3 & 0 & 90.52 \\
\hline 6 & 61 & 24 & 38 & 26 & 0.2 & 0 & 90.52 \\
\hline 7 & 79 & 18 & 38 & 26 & 0.1 & 0 & 90.52 \\
\hline 8 (image layer) & 97 & 18 & 38 & 26 & 0.1 & 0 & 90.52 \\
\hline
\end{tabular}

Table 1.3. Soil properties used for modeled fields in the SPAW model for study area S in Sargent County, North Dakota.

[Soil description in parentheses from U.S. Department of Agriculture, 2020]

\begin{tabular}{|c|c|c|c|c|c|c|c|}
\hline Soil layer & $\begin{array}{c}\text { Depth, } \\
\text { in inches }\end{array}$ & $\begin{array}{l}\text { Thickness, } \\
\text { in inches }\end{array}$ & $\begin{array}{c}\text { Sand } \\
\text { weight, } \\
\text { in percent }\end{array}$ & $\begin{array}{c}\text { Clay } \\
\text { weight, } \\
\text { in percent }\end{array}$ & $\begin{array}{c}\text { Organic } \\
\text { matter } \\
\text { weight, } \\
\text { in percent }\end{array}$ & $\begin{array}{c}\text { Gravel } \\
\text { weight, } \\
\text { in percent }\end{array}$ & $\begin{array}{c}\text { Bulk } \\
\text { density, } \\
\text { in pounds } \\
\text { per cubic } \\
\text { foot }\end{array}$ \\
\hline \multicolumn{8}{|c|}{ Field 1 (Hecla-Garborg loamy fine sands, hydrologic soil group A) } \\
\hline 1 (evaporative layer) & 1 & 1 & 80 & 6 & 2 & 0 & 90.52 \\
\hline 3 & 11 & 5 & 80 & 6 & 2 & 0 & 90.52 \\
\hline 4 & 15 & 4 & 90 & 5 & 0.5 & 0 & 93.64 \\
\hline 5 & 26 & 11 & 92 & 4 & 0.5 & 0 & 99.88 \\
\hline 6 & 50 & 24 & 85 & 10 & 0.5 & 0 & 99.88 \\
\hline 7 & 74 & 24 & 85 & 10 & 0.5 & 0 & 99.88 \\
\hline
\end{tabular}


Table 1.4. Depth-capacity curve used in pond model portion of SPAW model for study area B in Barnes County, North Dakota.

\begin{tabular}{ccc}
\hline $\begin{array}{c}\text { Depth, } \\
\text { in feet }\end{array}$ & $\begin{array}{c}\text { Area, } \\
\text { in acres }\end{array}$ & $\begin{array}{c}\text { Volume, in } \\
\text { acre-feet }\end{array}$ \\
\hline 0.0 & 0.0000 & 0.0000 \\
0.1 & 0.0001 & 0.0000 \\
0.5 & 0.0169 & 0.0034 \\
0.6 & 0.0821 & 0.0093 \\
0.7 & 0.1407 & 0.0149 \\
0.7 & 0.2189 & 0.0239 \\
0.8 & 0.3830 & 0.0450 \\
0.9 & 0.7114 & 0.0887 \\
1.1 & 3.1133 & 0.5668 \\
1.4 & 7.9640 & 1.9515 \\
1.9 & 20.3289 & 9.0247 \\
2.4 & 28.6005 & 21.2571 \\
2.9 & 33.1726 & 36.7003 \\
3.4 & 36.3857 & 54.0899 \\
3.9 & 39.3884 & 73.0334 \\
4.0 & 40.1652 & 79.0000 \\
\hline
\end{tabular}


Table 1.5. Depth-capacity curves used in pond model portion of SPAW model for study area D in Dickey County, North Dakota. $[--$, no data $]$

\begin{tabular}{|c|c|c|c|c|c|c|c|c|c|c|}
\hline \multirow{2}{*}{$\begin{array}{l}\text { Depth, } \\
\text { in feet }\end{array}$} & \multicolumn{2}{|c|}{ Pond 1} & \multicolumn{2}{|c|}{ Pond 2} & \multicolumn{2}{|c|}{ Pond 3} & \multicolumn{2}{|c|}{ Pond 4} & \multicolumn{2}{|c|}{ Pond 5} \\
\hline & $\begin{array}{l}\text { Area, } \\
\text { in acres }\end{array}$ & $\begin{array}{l}\text { Volume, in } \\
\text { acre-feet }\end{array}$ & $\begin{array}{l}\text { Area, } \\
\text { in acres }\end{array}$ & $\begin{array}{l}\text { Volume, in } \\
\text { acre-feet }\end{array}$ & $\begin{array}{l}\text { Area, } \\
\text { in acres }\end{array}$ & $\begin{array}{l}\text { Volume, in } \\
\text { acre-feet }\end{array}$ & $\begin{array}{l}\text { Area, } \\
\text { in acres }\end{array}$ & $\begin{array}{l}\text { Volume, in } \\
\text { acre-feet }\end{array}$ & $\begin{array}{l}\text { Area, } \\
\text { in acres }\end{array}$ & $\begin{array}{l}\text { Volume, in } \\
\text { acre-feet }\end{array}$ \\
\hline 0.0 & 0.0000 & 0.0000 & 0.0000 & 0.0000 & 0.0000 & 0.0000 & 0.0000 & 0.0000 & 0.0000 & 0.0000 \\
\hline 0.2 & 0.0011 & 0.0001 & 0.0023 & 0.0002 & 0.0023 & 0.0002 & 0.0028 & 0.0002 & 0.0036 & 0.0003 \\
\hline 0.4 & 0.0036 & 0.0005 & 0.0084 & 0.0012 & 0.0083 & 0.0012 & 0.0100 & 0.0014 & 0.0087 & 0.0015 \\
\hline 0.6 & 0.0060 & 0.0015 & 0.0155 & 0.0036 & 0.0168 & 0.0036 & 0.0244 & 0.0046 & 0.0163 & 0.0039 \\
\hline 0.8 & 0.0084 & 0.0029 & 0.0221 & 0.0073 & 0.0266 & 0.0080 & 0.0494 & 0.0119 & 0.0312 & 0.0086 \\
\hline 1.0 & 0.0110 & 0.0049 & 0.0283 & 0.0124 & 0.0374 & 0.0143 & 0.0758 & 0.0244 & 0.0526 & 0.0168 \\
\hline 1.2 & 0.0137 & 0.0073 & 0.0342 & 0.0186 & 0.0496 & 0.0230 & 0.1029 & 0.0423 & 0.0829 & 0.0302 \\
\hline 1.4 & 0.0167 & 0.0104 & 0.0400 & 0.0261 & 0.0631 & 0.0343 & 0.1327 & 0.0657 & 0.1170 & 0.0502 \\
\hline 1.6 & 0.0200 & 0.0141 & 0.0458 & 0.0346 & 0.0790 & 0.0485 & 0.1700 & 0.0959 & 0.1549 & 0.0773 \\
\hline 1.8 & 0.0237 & 0.0184 & 0.0517 & 0.0444 & 0.0954 & 0.0659 & 0.2117 & 0.1340 & 0.1999 & 0.1126 \\
\hline 2.0 & 0.0278 & 0.0236 & 0.0576 & 0.0553 & 0.1122 & 0.0867 & 0.2559 & 0.1808 & 0.2508 & 0.1576 \\
\hline 2.2 & 0.0323 & 0.0296 & 0.0638 & 0.0675 & 0.1299 & 0.1108 & 0.3017 & 0.2365 & 0.3055 & 0.2132 \\
\hline 2.4 & 0.0376 & 0.0365 & 0.0702 & 0.0808 & 0.1488 & 0.1387 & 0.3490 & 0.3015 & 0.3625 & 0.2800 \\
\hline 2.6 & 0.0437 & 0.0447 & 0.0785 & 0.0956 & 0.1695 & 0.1705 & 0.3985 & 0.3762 & 0.4227 & 0.3584 \\
\hline 2.8 & 0.0511 & 0.0541 & 0.0898 & 0.1124 & 0.1919 & 0.2066 & 0.4497 & 0.4610 & 0.4852 & 0.4492 \\
\hline 3.0 & 0.0605 & 0.0652 & 0.1050 & 0.1318 & 0.2154 & 0.2473 & 0.5027 & 0.5563 & 0.5472 & 0.5524 \\
\hline 3.2 & 0.0734 & 0.0785 & 0.1233 & 0.1546 & 0.2394 & 0.2928 & 0.5576 & 0.6623 & 0.6075 & 0.6679 \\
\hline 3.4 & 0.0910 & 0.0949 & 0.1425 & 0.1812 & 0.2636 & 0.3431 & 0.6138 & 0.7794 & 0.6658 & 0.7953 \\
\hline 3.6 & 0.1132 & 0.1152 & 0.1623 & 0.2117 & 0.2884 & 0.3983 & 0.6709 & 0.9078 & 0.7225 & 0.9342 \\
\hline 3.8 & 0.1472 & 0.1410 & 0.1824 & 0.2461 & 0.3145 & 0.4585 & 0.7291 & 1.0478 & 0.7777 & 1.0842 \\
\hline 4.0 & 0.1941 & 0.1750 & 0.2026 & 0.2846 & 0.3426 & 0.5242 & 0.7887 & 1.1996 & 0.8313 & 1.2451 \\
\hline 4.2 & 0.2476 & 0.2191 & 0.2230 & 0.3272 & 0.3759 & 0.5959 & 0.8499 & 1.3634 & 0.8830 & 1.4166 \\
\hline 4.4 & 0.3015 & 0.2740 & 0.2439 & 0.3739 & 0.4126 & 0.6748 & 0.9129 & 1.5397 & 0.9327 & 1.5982 \\
\hline 4.6 & 0.3541 & 0.3396 & 0.2652 & 0.4248 & 0.4472 & 0.7608 & 0.9776 & 1.7287 & 0.9800 & 1.7895 \\
\hline 4.8 & 0.4057 & 0.4156 & 0.2869 & 0.4800 & 0.4795 & 0.8535 & 1.0442 & 1.9309 & 1.0246 & 1.9900 \\
\hline 5.0 & 0.4550 & 0.5017 & 0.3089 & 0.5395 & 0.5098 & 0.9524 & 1.1102 & 2.1463 & 1.0667 & 2.1992 \\
\hline 5.2 & 0.5008 & 0.5974 & 0.3313 & 0.6036 & 0.5380 & 1.0573 & 1.1743 & 2.3748 & 1.1064 & 2.4165 \\
\hline 5.4 & 0.5433 & 0.7018 & 0.3538 & 0.6721 & 0.5646 & 1.1675 & 1.2355 & 2.6158 & -- & -- \\
\hline 5.6 & 0.5827 & 0.8145 & 0.3764 & 0.7451 & 0.5895 & 1.2830 & 1.2931 & 2.8688 & -- & -- \\
\hline 5.8 & 0.6195 & 0.9348 & 0.3985 & 0.8226 & 0.6126 & 1.4032 & 1.3472 & 3.1328 & -- & -- \\
\hline 6.0 & 0.6538 & 1.0621 & 0.4197 & 0.9044 & 0.6342 & 1.5279 & 1.3980 & 3.4074 & -- & -- \\
\hline 6.2 & 0.6571 & 1.0752 & 0.4399 & 0.9904 & 0.6414 & 1.5726 & 1.4460 & 3.6919 & -- & -- \\
\hline 6.4 & -- & -- & 0.4590 & 1.0803 & -- & -- & 1.4913 & 3.9856 & -- & -- \\
\hline 6.6 & -- & -- & 0.4769 & 1.1739 & -- & -- & 1.5342 & 4.2882 & -- & -- \\
\hline 6.8 & -- & -- & 0.4938 & 1.2710 & -- & -- & 1.5748 & 4.5992 & -- & -- \\
\hline 7.0 & -- & -- & 0.5097 & 1.3714 & -- & -- & 1.6133 & 4.9180 & -- & -- \\
\hline 7.2 & -- & -- & 0.5195 & 1.4383 & -- & -- & 1.6496 & 5.2443 & -- & -- \\
\hline 7.4 & -- & -- & -- & -- & -- & -- & 1.6841 & 5.5777 & -- & -- \\
\hline
\end{tabular}


Table 1.6. Depth-capacity curve used in pond model portion of SPAW model for study area S in Sargent County, North Dakota.

\begin{tabular}{ccc}
\hline Depth, in feet & $\begin{array}{c}\text { Area, } \\
\text { in acres }\end{array}$ & $\begin{array}{c}\text { Volume, } \\
\text { in acre-feet }\end{array}$ \\
\hline 0.0 & 0.0000 & 0.0000 \\
0.2 & 0.0190 & 0.0019 \\
0.4 & 0.0629 & 0.0101 \\
0.6 & 0.1119 & 0.0276 \\
0.8 & 0.1642 & 0.0552 \\
1.0 & 0.2136 & 0.0930 \\
1.2 & 0.2713 & 0.1415 \\
1.4 & 0.3152 & 0.2001 \\
1.6 & 0.3846 & 0.2701 \\
1.8 & 0.4519 & 0.3537 \\
2.0 & 0.5394 & 0.4529 \\
2.2 & 0.6395 & 0.5708 \\
\hline
\end{tabular}

Table 1.7. Culvert characteristics used to estimate flow between wetlands included in the SPAW model developed for study area D in Dickey County, North Dakota.

[no., number; --, no data]

\begin{tabular}{cccccccccc}
\hline $\begin{array}{c}\text { Upstream } \\
\text { wetland } \\
\text { (site no., } \\
\text { fig. 1) }\end{array}$ & $\begin{array}{c}\text { Downstream } \\
\text { wetland } \\
\text { (site no., } \\
\text { fig. 1) }\end{array}$ & $\begin{array}{c}\text { Culvert inlet } \\
\text { depth, } \\
\text { in feet } \\
\text { above bot- } \\
\text { tom } \\
\text { of inflow } \\
\text { wetland }\end{array}$ & $\begin{array}{c}\text { Culvert } \\
\text { outflow } \\
\text { depth, } \\
\text { in feet } \\
\text { above bot- } \\
\text { tom } \\
\text { of inflow } \\
\text { wetland }\end{array}$ & $\begin{array}{c}\text { Culvert } \\
\text { length, } \\
\text { in feet }\end{array}$ & $\begin{array}{c}\text { Culvert } \\
\text { diameter, } \\
\text { in feet }\end{array}$ & $\begin{array}{c}\text { Flow type } \\
\text { (Carter, } \\
\text { 1957) }\end{array}$ & $\begin{array}{c}\text { Manning's } \\
\text { roughness } \\
\text { (Chow, } \\
\text { 1959) }\end{array}$ & $\begin{array}{c}\text { Slope, in } \\
\text { foot per foot }\end{array}$ & $\begin{array}{c}\text { Peak } \\
\text { discharge, } \\
\text { in cubic feet } \\
\text { per second }\end{array}$ \\
\hline 1 & 2 & 2.4 & 2.1 & 23.25 & 1.6 & 5 & -- & 0.01 & 12 \\
2 & 3 & 3.0 & 2.4 & 27.25 & 2 & 6 & -- & 0.02 & 17 \\
3 & 4 & 1.1 & -- & 25 & -- & -- & 0.08 & 0.04 & 48 \\
4 & 5 & 1.5 & 1.0 & 26 & 2 & 5 & -- & 0.01 & 20 \\
5 & Outlet & 1.2 & 0.8 & 18.25 & 2 & 5 & -- & 0.02 & 23 \\
\hline
\end{tabular}


Table 1.8. Monthly mean subsurface drainage discharge used for input to the pond model portion of the SPAW models for study areas B, D, and S in Barnes, Dickey, and Sargent Counties, respectively.

\begin{tabular}{lccc}
\hline & \multicolumn{3}{c}{ Monthly mean subsurface drainage discharge, in gallons per minute } \\
\cline { 2 - 4 } & & Study area & S \\
\cline { 2 - 4 } & B & D & 0.04 \\
\hline January & 0.04 & 0.37 & 0.05 \\
February & 0.05 & 0.99 & 0.33 \\
March & 0.17 & 3.35 & 0.48 \\
April & 0.30 & 3.30 & 0.49 \\
May & 0.47 & 4.22 & 0.07 \\
June & 0.28 & 3.30 & 0.00 \\
July & 0.04 & 0.75 & 0.00 \\
August & 0.00 & 0.02 & 0.01 \\
September & 0.00 & 0.12 & 0.11 \\
October & 0.10 & 2.48 & 0.08 \\
November & 0.09 & 0.98 & 0.03 \\
December & 0.05 & 0.61 & \\
\hline
\end{tabular}

\section{References Cited}

Carter, R.W., 1957, Computation of peak discharge at culverts: U.S. Geological Survey Circular 376, 25 p., accessed August 2020 at https://pubs.er.usgs.gov/pu.blication/cir376.

Chow, V.T., 1959, Open Channel Hydraulics: New York, N.Y., McGraw-Hill, 680 p.

U.S. Department of Agriculture, 2020, Web Soil Survey: accessed June 3, 2020, at https://websoilsurvey.sc.egov .usda.gov/App/HomePage.htm. 


\section{Appendix 2. Additional Model Parameters Used in DRAINMOD Model Applications at Study Areas B, D, and S}

Table 2.1. Soil-water characteristic values for soil layers used in the DRAINMOD model for study area B in Barnes County, North Dakota.

\begin{tabular}{|c|c|c|c|c|c|c|c|}
\hline \multirow{2}{*}{$\begin{array}{c}\text { Head, } \\
\text { in inches }\end{array}$} & \multicolumn{7}{|c|}{ Soil-water characteristic, in cubic inches per cubic inch for layer depth ranges in inches } \\
\hline & 0-5 & 5-11 & $11-24$ & 24-39 & $39-50$ & $50-85$ & 85-125 \\
\hline 0 & 0.589 & 0.513 & 0.452 & 0.433 & 0.367 & 0.369 & 0.361 \\
\hline 20 & 0.528 & 0.451 & 0.371 & 0.34 & 0.255 & 0.254 & 0.335 \\
\hline 30 & 0.502 & 0.425 & 0.344 & 0.312 & 0.228 & 0.227 & 0.32 \\
\hline 59 & 0.451 & 0.374 & 0.295 & 0.263 & 0.185 & 0.184 & 0.28 \\
\hline 79 & 0.428 & 0.352 & 0.275 & 0.245 & 0.169 & 0.169 & 0.26 \\
\hline 130 & 0.389 & 0.315 & 0.244 & 0.215 & 0.145 & 0.145 & 0.224 \\
\hline 197 & 0.358 & 0.286 & 0.22 & 0.193 & 0.129 & 0.129 & 0.196 \\
\hline 394 & 0.312 & 0.244 & 0.187 & 0.163 & 0.107 & 0.107 & 0.154 \\
\hline
\end{tabular}

Table 2.2. Soil-water characteristic values for soil layers used in the DRAINMOD model for study area D in Dickey County, North Dakota.

\begin{tabular}{|c|c|c|c|c|c|c|c|c|c|}
\hline \multirow{2}{*}{$\begin{array}{c}\text { Head, } \\
\text { in inches }\end{array}$} & \multicolumn{9}{|c|}{ Soil-water characteristic, in cubic inches per cubic inch for layer depth ranges in inches } \\
\hline & $0-2$ & $2-4$ & 4-8 & 8-14 & 14-18 & $18-29$ & 29-39 & $39-61$ & $61-79$ \\
\hline 0 & 0.53 & 0.461 & 0.432 & 0.446 & 0.443 & 0.446 & 0.451 & 0.413 & 0.406 \\
\hline 20 & 0.422 & 0.369 & 0.365 & 0.364 & 0.384 & 0.406 & 0.417 & 0.361 & 0.367 \\
\hline 30 & 0.391 & 0.341 & 0.34 & 0.338 & 0.36 & 0.385 & 0.399 & 0.34 & 0.348 \\
\hline 79 & 0.319 & 0.273 & 0.276 & 0.271 & 0.291 & 0.316 & 0.331 & 0.281 & 0.29 \\
\hline 130 & 0.286 & 0.242 & 0.245 & 0.241 & 0.257 & 0.277 & 0.291 & 0.251 & 0.258 \\
\hline 197 & 0.262 & 0.219 & 0.222 & 0.218 & 0.231 & 0.247 & 0.259 & 0.228 & 0.233 \\
\hline 394 & 0.227 & 0.187 & 0.189 & 0.186 & 0.194 & 0.203 & 0.213 & 0.195 & 0.196 \\
\hline
\end{tabular}


Table 2.3. Soil-water characteristic values for soil layers used in the DRAINMOD model for study area S in Sargent County, North Dakota.

\begin{tabular}{ccccccc}
\hline \multirow{2}{*}{$\begin{array}{c}\text { Head, } \\
\text { in inches }\end{array}$} & \multicolumn{5}{c}{ Soil-water characteristic, in cubic inches per cubic inch for layer depth ranges in inches } \\
\cline { 2 - 7 } & $\mathbf{0 - 3}$ & $\mathbf{3 - 7}$ & $\mathbf{7 - 1 2}$ & $\mathbf{1 2 - 1 9}$ & $\mathbf{1 9 - 3 7}$ & $\mathbf{3 7 - 6 0}$ \\
\hline 0 & 0.413 & 0.390 & 0.359 & 0.374 & 0.374 & 0.390 \\
10 & 0.321 & 0.316 & 0.285 & 0.308 & 0.308 & 0.321 \\
20 & 0.229 & 0.232 & 0.207 & 0.229 & 0.228 & 0.238 \\
30 & 0.179 & 0.183 & 0.163 & 0.182 & 0.181 & 0.189 \\
39 & 0.150 & 0.154 & 0.137 & 0.153 & 0.153 & 0.159 \\
59 & 0.119 & 0.122 & 0.109 & 0.122 & 0.122 & 0.127 \\
79 & 0.102 & 0.105 & 0.095 & 0.106 & 0.105 & 0.109 \\
130 & 0.082 & 0.085 & 0.077 & 0.086 & 0.085 & 0.088 \\
197 & 0.071 & 0.074 & 0.068 & 0.075 & 0.075 & 0.077 \\
394 & 0.060 & 0.064 & 0.059 & 0.065 & 0.064 & 0.066 \\
1,969 & 0.052 & 0.055 & 0.051 & 0.056 & 0.056 & 0.057 \\
5,906 & 0.050 & 0.054 & 0.050 & 0.055 & 0.055 & 0.056 \\
\hline
\end{tabular}

Table 2.4. Drainage volume and upward flux from the water table used in the DRAINMOD models for study areas B, D, and $S$ in Barnes, Dickey, and Sargent Counties, respectively.

\begin{tabular}{ccccccc}
\hline \multirow{2}{*}{$\begin{array}{c}\text { Water table } \\
\text { depth, } \\
\text { in inches }\end{array}$} & \multicolumn{7}{c}{ Study area } \\
\cline { 2 - 7 } & $\begin{array}{c}\text { Volume } \\
\text { drained, } \\
\text { in inches }\end{array}$ & $\begin{array}{c}\text { Upward flux, } \\
\text { in inches } \\
\text { per hour }\end{array}$ & $\begin{array}{c}\text { Volume } \\
\text { drained, } \\
\text { in inches }\end{array}$ & $\begin{array}{c}\text { Upward flux, } \\
\text { in inches } \\
\text { per hour }\end{array}$ & $\begin{array}{c}\text { Volume } \\
\text { drained, } \\
\text { in inches }\end{array}$ & $\begin{array}{c}\text { Upward flux, } \\
\text { in inches } \\
\text { per hour }\end{array}$ \\
\hline 0 & 0.0000 & 0.1969 & 0.0000 & 0.1969 & 0.0000 & 0.1969 \\
1 & 0.0024 & 0.1224 & 0.0043 & 0.0449 & 0.0063 & 0.1658 \\
2 & 0.0087 & 0.0493 & 0.0177 & 0.0191 & 0.0260 & 0.0673 \\
4 & 0.0197 & 0.0278 & 0.0386 & 0.0111 & 0.0583 & 0.0435 \\
5 & 0.0346 & 0.0189 & 0.0665 & 0.0079 & 0.1016 & 0.0296 \\
6 & 0.0543 & 0.0130 & 0.0992 & 0.0058 & 0.1555 & 0.0217 \\
8 & 0.0969 & 0.0076 & 0.1646 & 0.0039 & 0.2685 & 0.0137 \\
10 & 0.1512 & 0.0050 & 0.2461 & 0.0029 & 0.4106 & 0.0096 \\
12 & 0.2189 & 0.0035 & 0.3413 & 0.0022 & 0.5819 & 0.0069 \\
14 & 0.3031 & 0.0027 & 0.4484 & 0.0018 & 0.7811 & 0.0051 \\
16 & 0.4039 & 0.0020 & 0.5673 & 0.0015 & 1.0098 & 0.0039 \\
18 & 0.5220 & 0.0017 & 0.6969 & 0.0013 & 1.2685 & 0.0030 \\
24 & 0.9713 & 0.0009 & 1.1110 & 0.0008 & 2.1839 & 0.0015 \\
30 & 1.5476 & 0.0006 & 1.5425 & 0.0006 & 3.2488 & 0.0009 \\
35 & 2.2512 & 0.0004 & 1.9945 & 0.0005 & 4.4362 & 0.0006 \\
47 & 3.9827 & 0.0002 & 3.0043 & 0.0003 & 7.0783 & 0.0003 \\
59 & 6.1126 & 0.0001 & 4.2626 & 0.0002 & 9.9949 & 0.0002 \\
79 & 10.1012 & 0.0000 & 6.6591 & 0.0001 & 15.2772 & 0.0000 \\
197 & 27.0866 & 0.0000 & 24.5047 & 0.0000 & 39.3701 & 0.0000 \\
394 & 39.3701 & 0.0000 & 39.3701 & 0.0000 & 39.3701 & 0.0000 \\
\hline
\end{tabular}


Table 2.5. Infiltration parameters used in the Green-Ampt equation in the DRAINMOD models for study areas B, D, and $S$ in Barnes, Dickey, and Sargent Counties, respectively.

\begin{tabular}{ccccccc}
\hline \multirow{2}{*}{$\begin{array}{c}\text { Water table } \\
\text { depth, } \\
\text { in inches }\end{array}$} & \multicolumn{7}{c}{ Study area } \\
\cline { 2 - 7 } & A coefficient & B coefficient & A coefficient & B coefficient & A coefficient & B coefficient \\
\hline 0 & 0 & 0.04 & 0 & 0.06 & 0 & 0.06 \\
4 & 0 & 0.04 & 0.01 & 0.06 & 0.03 & 0.06 \\
8 & 0.01 & 0.04 & 0.01 & 0.05 & 0.06 & 0.06 \\
16 & 0.02 & 0.04 & 0.02 & 0.05 & 0.11 & 0.06 \\
24 & 0.03 & 0.04 & 0.03 & 0.05 & 0.15 & 0.06 \\
31 & 0.04 & 0.04 & 0.04 & 0.05 & 0.18 & 0.06 \\
39 & 0.04 & 0.04 & 0.04 & 0.05 & 0.2 & 0.06 \\
59 & 0.16 & 0.04 & 0.1 & 0.05 & 0.27 & 0.06 \\
79 & 0.16 & 0.04 & 0.1 & 0.05 & 0.27 & 0.06 \\
394 & 0.16 & 0.04 & 0.1 & 0.05 & 0.27 & 0.06 \\
\hline
\end{tabular}

Table 2.6. Soil-water content at saturation values used in the DRAINMOD models for study areas B, D, and S in Barnes, Dickey, and Sargent Counties, respectively.

\begin{tabular}{cccc}
\hline \multirow{2}{*}{$\begin{array}{c}\text { Head } \\
\text { in inches }\end{array}$} & \multicolumn{3}{c}{ Soil-water characteristic, in cubic inches per cubic inch } \\
\cline { 2 - 4 } & B & Study area & S \\
\cline { 2 - 4 } & 0.45 & 0.45 & 0.36 \\
-10 & 0.41 & 0.40 & 0.28 \\
-20 & 0.37 & 0.36 & 0.20 \\
-30 & 0.34 & 0.34 & 0.16 \\
-39 & 0.32 & 0.32 & 0.14 \\
-59 & 0.30 & 0.29 & 0.10 \\
-79 & 0.28 & 0.27 & 0.08 \\
-130 & 0.24 & 0.24 & 0.08 \\
-197 & 0.22 & 0.22 & 0.06 \\
-394 & 0.19 & 0.19 & 0.06 \\
$-1,969$ & 0.13 & 0.13 & 0.04 \\
$-5,906$ & 0.11 & 0.11 & 0.04 \\
\hline
\end{tabular}


Table 2.7. Saturated lateral hydraulic conductivity values used in the DRAINMOD models for study areas B, D, and S in Barnes, Dickey, and Sargent Counties, respectively.

\begin{tabular}{|c|c|c|c|}
\hline \multirow{3}{*}{$\begin{array}{l}\text { Depth of layer, } \\
\text { in inches }\end{array}$} & \multicolumn{3}{|c|}{ Saturated lateral hydraulic conductivity, in inches per hour } \\
\hline & \multicolumn{3}{|c|}{ Study area } \\
\hline & B & D & $\mathbf{S}$ \\
\hline 0 to 11 & 0.92 & 0.92 & 4.58 \\
\hline 11 to 22 & 0.12 & 0.12 & 0.61 \\
\hline 22 to 28 & 0.49 & 0.49 & 2.44 \\
\hline 28 to 43 & 0.00 & 0.00 & 0.12 \\
\hline 43 to 114 & 0.00 & 0.00 & 0.00 \\
\hline
\end{tabular}

Table 2.8. Monthly evapotranspiration correction factors and root depths used in DRAINMOD model applications at study areas B, D, and S, in Barnes, Dickey, and Sargent Counties, respectively, 2003-18.

\begin{tabular}{lcccccc}
\hline & \multicolumn{7}{c}{ Study area } \\
\cline { 2 - 7 } \multicolumn{1}{c}{ Month } & \multicolumn{7}{c}{ B } & \multicolumn{2}{c}{$\mathbf{D}$} & S \\
\cline { 2 - 7 } & $\begin{array}{c}\text { Evapotranspiration } \\
\text { correction factor }\end{array}$ & $\begin{array}{c}\text { Root depth, } \\
\text { in inches }\end{array}$ & $\begin{array}{c}\text { Evapotranspiration } \\
\text { correction factor }\end{array}$ & $\begin{array}{c}\text { Root depth, } \\
\text { in inches }\end{array}$ & $\begin{array}{c}\text { Evapotranspiration } \\
\text { correction factor }\end{array}$ & $\begin{array}{c}\text { Root depth, } \\
\text { in inches }\end{array}$ \\
\hline January & 6 & 1.2 & 1 & 1.2 & 6 & 1.2 \\
February & 2.5 & 1.2 & 1 & 1.2 & 2.5 & 1.2 \\
March & 1.6 & 1.2 & 1 & 1.2 & 1.6 & 1.2 \\
April & 1.1 & 1.2 to 1.6 & 1 & 1.2 to 1.6 & 1.1 & 1.2 to 1.6 \\
May & 1.4 & 1.6 to 5.9 & 1 & 1.6 to 5.9 & 1.4 & 1.6 to 5.9 \\
June & 3.3 & 9.8 to 11.8 & 1 & 9.8 to 11.8 & 3.3 & 9.8 to 11.8 \\
July & 6.5 & 11.8 & 1 & 11.8 & 6.5 & 11.8 \\
August & 2.3 & 11.8 & 1 & 11.8 & 2.3 & 11.8 \\
September & 1.2 & 1.2 to 7.9 & 1 & 1.2 to 7.9 & 1.2 & 1.2 to 7.9 \\
October & 1.1 & 1.2 & 1 & 1.2 & 1.1 & 1.2 \\
November & 1.9 & 1.2 & 1 & 1.2 & 1.9 & 1.2 \\
December & 5.9 & 1.2 & 1 & 1.2 & 5.9 & 1.2 \\
\hline
\end{tabular}


For more information about this publication, contact: Director, USGS Dakota Water Science Center

821 East Interstate Avenue, Bismarck, ND 58503

1608 Mountain View Road, Rapid City, SD 57702

605-394-3200

For additional information, visit: https://www.usgs.gov/centers/ dakota-water

Publishing support provided by the

Rolla Publishing Service Center 
